Historic, Archive Document

Do not assume content reflects current scientific knowledge, policies, or practices. 


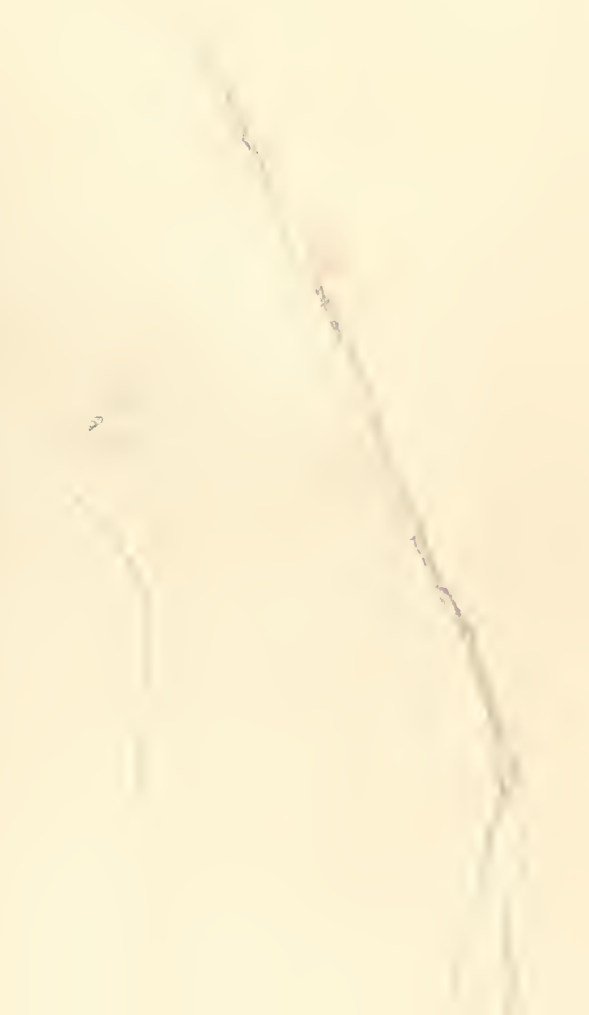


Fourth Edition

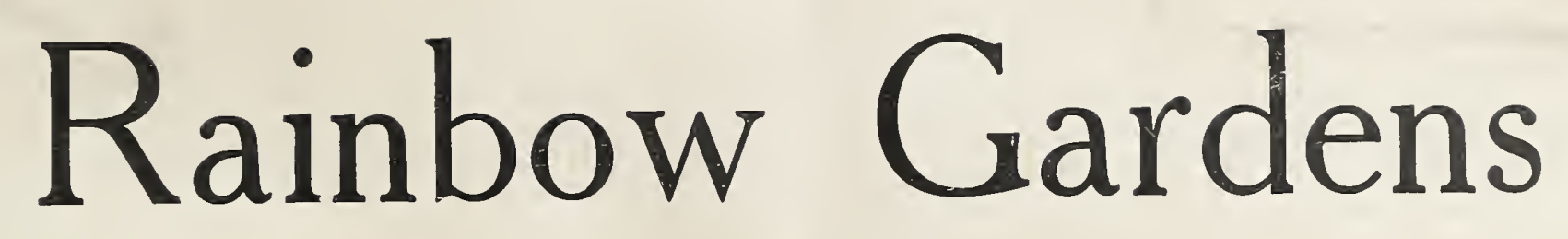

Growers and Importers of Choice Varieties

\section{Irises, Peonies and Gladioli}

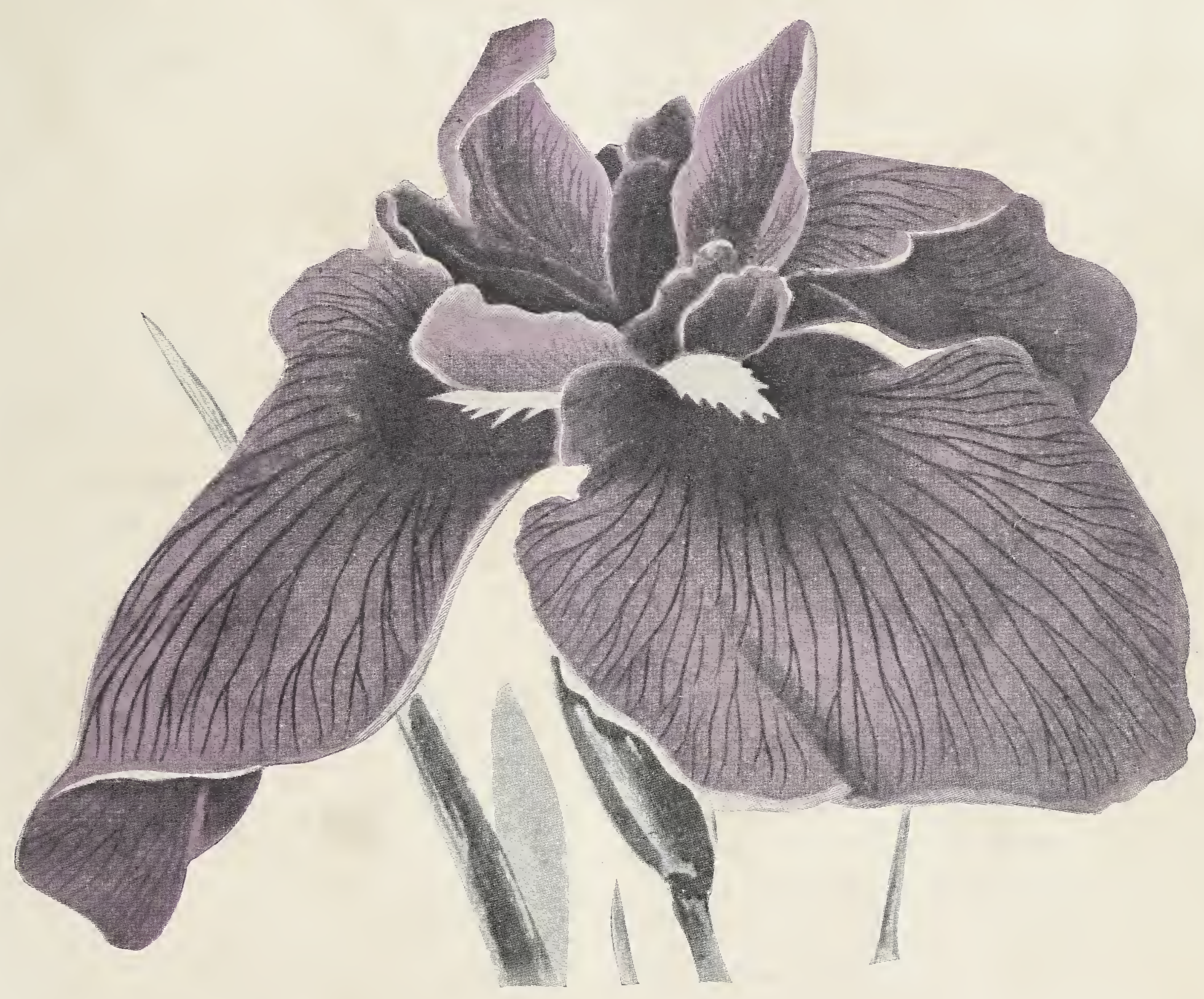

JOHN S. CROOKS and GRACE W. CROOKS

Proprictors

1980 Montreal Avenue

S A I N T PAUL, M I N ESOTA 


\section{How To Order By Mail}

Orders: When sending orders please use the Order Blank furnished with this catalogue, being very careful that your name and address are written very plainly on each order.

All orders are booked in the rotation in which they are received. The earlier they come in the more certain will be the patron of securing the plants and bulbs of his choice. All sales are made subject to stock on hand at time of filling order.

Terms: Cash should accompany each order. Remittances can be made by post office or express money order or bank draft or check. On account of the expense in hand. ling we cannot fill orders for goods amounting to less than \$1.00. By reason of exchange charged us Canadian customers, please remit by money order or Chicago or N. Y. Draft.

Prices: All prices in this catalog are net and will not be deviated from as we wish to treat everyone alike.

Shipping Facilities: We ship all goods either by express or by parcel post the purchaser paying charges. Customers who desire us to prepay express charges or parcel post can remit enough to cover and any surplus will be returned, or if preferred extra plants will be sent to cover the difference. We will deliver orders amounting to $\$ 3.00$ or more, between April 1st and November 1st, free of charge to any point within 5 miles from the business centers of either St. Paul or Minneapolis. Small orders can also be called for and delivered at 701-2 Commerce Bldg., St. Paul, Minn.

Shipment of Goods: lrises:- Spring shipments commence early in April as soon as weather and root growth conditions permit, continuing until May 15th, when growth becomes too far advanced for transplanting. Fall shipments commence about August 20 th and continue until the ground freezes in November. Peonies:- Spring shipments will be made just as early in April and May as possible. Fall shipments are made from Sept. ist until the ground freezes in November. Orders for Irises and Peonies received after the ground freezes in the fall will be forwarded early the following spring. Gladioli:We ship Gladioli in November until cold weather commences and from April lst until May 10th when we plant our stock.

Quality of Stock: We propose to send out strong plants and sound bulbs true to name and hold ourselves in readiness at any time to replace, on proper proof, any stock that may prove otherwise; but we shall not at any time be liable for any amount greater than the original price of the stock. Every purchase is made from us on these terms.

Complaints: If any, as to quality of goods, etc., can be entertained only when made immediately on receipt of goods.

Substitution: Carrying as we do, such a large number of varieties of Irises, it is obvious that at times, particularly at the end of a season, we may be unable to furnish some varieties. Therefore we ask permission to substitute varieties of Irises of equal merit in their place. On our order blank please fill in yes or no on the correct line. If you do not wish us to substitute we will return your money for the varieties not supplied. In case you write neither "yes" nor "no" we shall understand that you do not object to our substituting as above.

Packing: We make no charge for packing. Plants will be packed in good condition. We guarantee safe arrival of packages sent by express. After they pass out of our control we do not guarantee that they will live as we then have no control over conditions surrounding them and the care they will then receive.

Our References: Any bank in St. Paul.

Cut Flowers: We will be pleased at all times to quote prices for cut flowers of Irises, Peonies and Gladioli grown by us.

\section{PRICES IN THIS CATALOGUE CANCEL ALL PREVIOUS PRICES AND ARE SUBJECT TO CHANGE WITHOUT NOTICE}

\section{N D E X}

Irises-

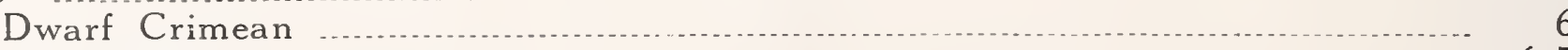

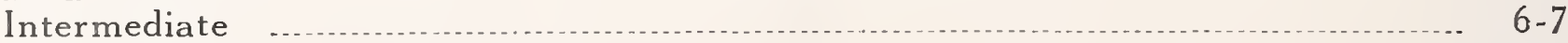

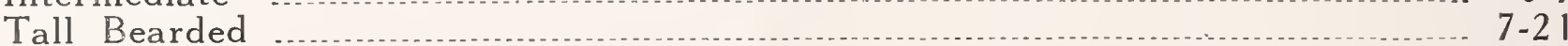

Beardless Irises _....................... 21-25

Japanese Irises ..................................... 23-25

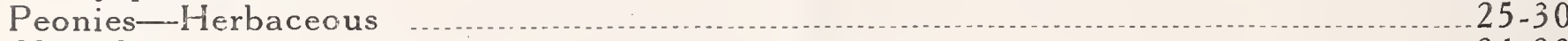

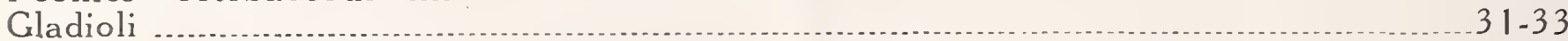

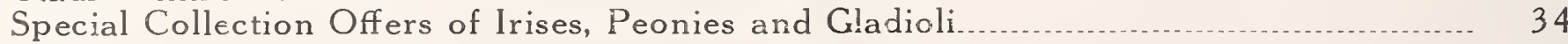




\section{Introduction}

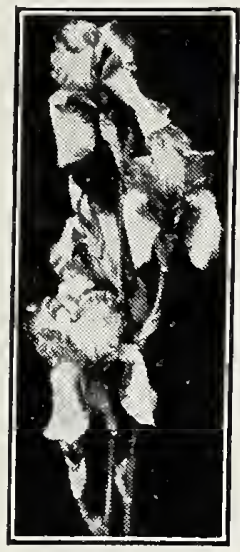

Rainbow Gardens derives its name from one of its specialties, the lris, the Greek word for which is Iridaceae, meaning Rainbow. It is located between St. Paul and Minneapolis at 1980 Montreal Avenue, near Cleveland Avenue, in St. Paul, Minnesota, about one mile north of Fort Snelling, two miles south of Grand and Cleveland Avenues and one mile south of Randolph and Cleveland Avenues.

It can be reached by automobile on Cleveland Avenue, either from Summit Avenue or from Fort Snelling, or by way of West 7 th Street, then out Montreal Avenue. Also by leaving the River Boulevard by a road known as Surrey St. running east from the Government Dam opposite the Soldiers' Home. By street car take either the Randolph extension line, ending at Randolph and Cleveland Avenues, and walking one mile south to Montreal Avenue; or by the Snelling-Minnehaha Line to Edgcumbe Road, then north on the Edgcumbe Road following our signs to Rainbow Gardens, a distance of about a mile.

Visitors are always welcome and any one interested in Irises, Peonies and Gladioli can select from the plants and bulbs in bloom the varieties desired. The different varieties of Irises bloom continuously from April until August 1st, the Tall Bearded Irises being at their height in this latitude between June $5 \mathrm{th}$ and $15 \mathrm{th}$, and the Japanese Irises between July 1 st and 15th. The Peonies flower during June and the Gladioli from July 15 th until frost in October, being at their best during August.

We specialize in Irises, Peonies and Gladioli only, and have imported heavily since our last Edition. We have added many magnificent new hybrids which will be of especial interest to our customers.

We believe Irises, Peonies and Gladioli to be the most satisfactory and dependable both for a flowering garden and for cut flowers for the home, giving the finest of flowers continuously from April until October.

By reason of our rich black sandy loam we are enabled to grow the finest of roots and bulbs.

Our varieties comprise a selection of Irises and Peonies that are novel, most beautiful and satisfactory and are grown to withstand not only the rigors of our Minnesota winters where the temperature occasionally falls to thirty degrees below zero, but the heat of our summer months as well, which is often very great. They are, therefore, acclimated to withstand the extremes of climate of any part of the United States or Canada. Our Gladioli have been carefully selected from the most beautiful of the hundreds of varieties and will give you flowers of which we know you will be extremely proud.

From time to time supplements will be furnished of varieties omitted temporarily in this catalogue until further stock can be obtained, and of new and imported stock and of varieties originated by us.

We trust that we may be instrumental in interesting you in these three great flowers, Irises, Peonies and Gladioli, and that we may have the pleasure of aiding you in the selection of varieties for your garden and to hear from you from time to time of your successes.

We wish to thank our many customers for their past favors and trust that their faith in us and in our goods as shown by their letters and repeated orders may continue.

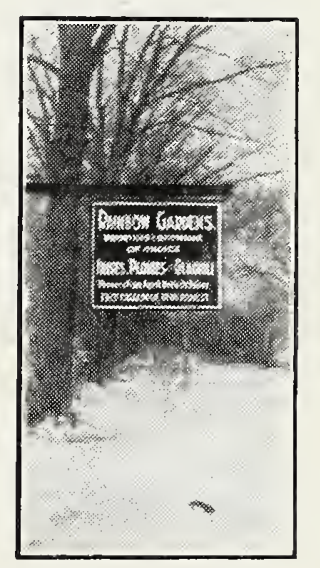

\section{RAINBOW GARDENS}

John S. Crooks and Grace W. Crooks, Proprietors 


\section{The Iris}

Iris, Iridaceae in Greek, was according to Greek mythology, the beautiful daughter of Thaumas and the Ocean nymph Electra. She was the goddess of the Rainbow and the messenger of the gods. As the rainbow united earth and heavens, Iris was the messenger of the gods to men. She was represented as of youthful origin, with wings of gold, who hurried with the swiftness of the wind from one end of the world to the other.

It is therefore most fitting that the gorgeous Irises should bear her name, for they are indeed the Rainbow flower with their varied hues.

The Iris has always been highly esteemed. Its use as an emblem is traced as far back as the time of the early Assyrians; in Egypt the Iris was borne on the scepters of the monarchs and as an emblem of power was carved on the brow of the Sphinx. In Greece, being the emblem of hope, they planted Irises on the tombs of their dead. In early times its roots were extensively used for various cures and medical purposes. The early Franks at the proclamation of their king raised him on a shield and placed an Iris in his hand and later it became the symbol of France. In 1340 Edward III' of England who claimed the throne of France used the Iris, or Fleur de Lys as it was called, on his shield with the English Lion and it remained upon the English shield until 1801. In Japan the Iris is a favorite flower and the month of June is celebrated with what is known as the Fete of the Iris. During that month the public conveyances are decorated with Irises and the water in their bath houses is perfumed with Iris root.

Shakespeare, Chaucer, Milton, Tennyson and many other writers have loved to dwell on the beauty of the Iris in their writings.

The Iris is a magnificent hardy perennial and a favorite flower. We are making a specialty of Irises at Rainbow Gardens because we believe that they are the most popular, satisfactory and beautiful perennial in the garden. They flower during a long period of time; they require practically no care; they multiply rapidly; they grow in practically any kind of soil; they are inexpensive; they are most beautiful and gorgeous in coloring, the delicate intermingling and blending of colors, their wonderful veining and delicious fragrance giving them a charm not possessed by any other flower; they withstand extreme heat and cold and are the best drought resisters amongst the perennials.

It is said that in Nebraska, one year, for fifty days, the mercury was 100 degrees and up with hot winds. That only two inches of rain fell during a period of four months. That all other plants and perennials vanished. The Irises, however, stood their ground and grew with wonderful tenacity through it all. The dry, hot spell we had during the summer of 1916 did not affect Irises in the least.

The stately habits of Irises, their gorgeous effects, their wonderful coloring and their freeness of bloom have well entitled them to the name of the "Orchid of the Hardy Gar. den," but Irises have the advantage of the orchid in delicacy of structure and in greater facility of culture.

Irises are adapted to almost every condition and climate. They can hold a place in the humble cottage garden with as much grace as in the most formal of gardens. For beds, borders, rockeries, walks, driveways, water gardens and around the edges of natural ponds and creeks there is nothing that equals them. While for a hilly dry location they are equally as well fitted.

Dwarf Irises are most suitable for borders of beds-followed by Intermediate varieties which are a little taller; then in a mass the many choice varieties of Tall Bearded Irises with a background of Japanese Irises and of Beardless Irises (Sections 1 and 2). This manner of planting assures not only a great diversity of color effects, but a continuously blooming garden, from April until August 1st. Or if in a water garden or along a stream, plant the Versicolor and Pseudo-Acorus varieties of Irises (See page 22) in or at the water's edge, next the Japanese varieties, then the Beardless Irises listed under Sections 1 and 2 (pages 21-22), then where the ground is dry the Tall Bearded Irises, then the Intermediates and Iastly the Dwarfs as a border.

The many wonderful varieties of Irises start to bloom in late March and April. These are the Dwarf Crimean Irises, which continue to bloom during April and May. 
Closely following these charming Irises, the Intermediate Irises with their larger and beautifully colored flowers, burst forth filling in the gap between the Dwarf Crimean Irises and the handsome Tall Bearded Irises, the flowers appearing during the latter part of April and during the month of May. Then follow the great Tall Bearded family with its hundreds of wonderful and beautiful hues. In quick succession come the Tall Sibericas and the Beardless Irises, amongst which are the tall varieties of Aurea, Monspur and Orientalis Gigantea until July ushers in the Japanese Irises, the magnificence of which surpasses any description which can be given, with blooms almost a foot in diameter on stems, some of which are five feet in height.

This variety continues to bloom here until August 1st. Again in the late fall a few of the Crimean Irises come forth once more into bloom, ending up the grand pageant of color. No flower has such continued and gorgeous bloom, requires such little carel or presents such a grand appearance, either in the garden or as a cut flower.

Many people have the erroneous idea that Irises will not thrive except where there is considerable moisture. This is a mistaken idea. Irises as a rule love the sunshine and with very few exceptions should be planted in dry soil. All the Dwarf, lntermediate and Tall Bearded lrises, all of the varieties listed in Sections 1 and 2 of the Beardless Irises, comprising in all about $85 \%$ of the entire group of Irises, require a dry, sunny location, the same as any other hardy perennial. The lrises listed under Section 2 of the Beardless Variety can be planted by the water side with their crowns above the water level, but can also with good results be planted in any dry location. Japanese Irises like plenty of moisture during the spring months but they will also grow well in dry soil if the ground is often stirred. The only varieties that will grow continuously in water or wet or boggy places are the Iris Versicolor and Iris Pseudo-Acorus varieties listed under Section 3 of the Beardless Irises on page 22 in this catalogue.

Rainbow Gardens possesses one of the largest and most magnificent collections of Irises in this country. We have over 600 varieties of Irises covering several acres of ground and including practically every beautiful, rare, hardy variety known to us. It you desire any special hardy variety of Iris which you do not find listed by us, we, probably have it, nevertheless, and can furnish it to you.

Abbreviations of Names of Originators used.

Barr-Peter Barr \& Sons, Eng.; Bliss-A. J. Bliss, Eng.; Cap.-W. J. Caparne, Guernsey; Cay.-Cayeux \& Leclerc, France; Dean-Mrs. J. Dean, U. S.; Den.-F. Denis, France; Dykes-W. R. Dykes, Eng.; Farr-B. H. Farr, U. S.; Fos.-Sir MichaeI Foster, Eng.; G. \& K.-Goos \& Koenemann, Germany; Hor.-Sir Arthur Hort, Eng.; Jacq.-Jacques, France; Ken.-A. Kennicott, U. S.; Lmn.-Lemon, France; Mar.-J. W. Marshall, Eng.; Mil.-Millet \& Fils, France; Park-Robt. Parker, Eng.; Per.-Amos Perry, Eng.; Sal.-John Salter, Eng.; Sturt.-Miss Grace Sturtevant, U. S.: Vilm.Andrieux, Vilmorin \& Cie, France; Ware-T. S. Ware, Eng.; Weir-Harrison Weir, Eng.; Wmsn.-E. B. Williamson, U. S.; Yeld-George Yeld, Eng.

Other abbreviations used are as follows:

S.-signifies "standards," or the three upper petals of the Iris. F.— "falls" or the three drooping or lower petals. A. M.- "Award of Merit;" F. C. C.-"First Class Certificate;" R. H. S._-"Royal Horticultural Society;" H. M._"Honorable Mention;" H. C._-"Highly Commended;" C._-"Commended;" Cert.- "Certificate;" M. H. S."Massachusetts Horticultural Society;" A. I. S.- "American Iris Society;" N. H. F."National Horticultural Society of France." The number before each variety is our catalogue and field number.

In our previous catalogues we have classified the Tall Bearded Irises according to color and species as follows:-Pallida-(pall.) Tall, strong growing, fragrant Irises of the most handsome shades of blue, Iavender and purple. Variegata-(var.) Where the standards are shades of yellow and the falls are of various colors. Amoena- (am.) Where the S. are white and the F. of various colors. Neglecta-(neg.) Where the S. range from lavender to purple. Plicata- $(\mathrm{pl})$ Where the flowers have a colored frilllike margin on a white ground, like Madam Chereau. Squalens-(sq.) Where the S. are various shades of copper, bronze and fawn, and the $F$. of various colors. We have retained abbreviations of these classifications in many instances in this edition-for instance, see Monsignor-neg. (neglecta), Vilm. (Vilmorin) originated by him in 1907. 
We have classified our tall bearded varieties alphabetically in this edition for the reason that many of the new varieties and importations are a combination of two or three of the above old classifications, making it difficult to classify them otherwise, and believing that they can be found more readily alphabetically.

We are indebted to the American Iris Society especially for their Check List of Originators and accepted names and same is followed by us to a considerable extent. Mr. Wister, the President of this Society, is to be thanked and congratulated for the results he has obtained through an immense amount of research and work on his part, and we wish to express our appreciation for his work and for that of the other active members of this Society, and to assure them that we will aid the Society in its work and research at all times as far as is within our power.

This illustration is furnished by the American Iris Society. It shows the names and positions of the various parts of the lris and will be an aid to you in understanding the descriptions of our varieties following.

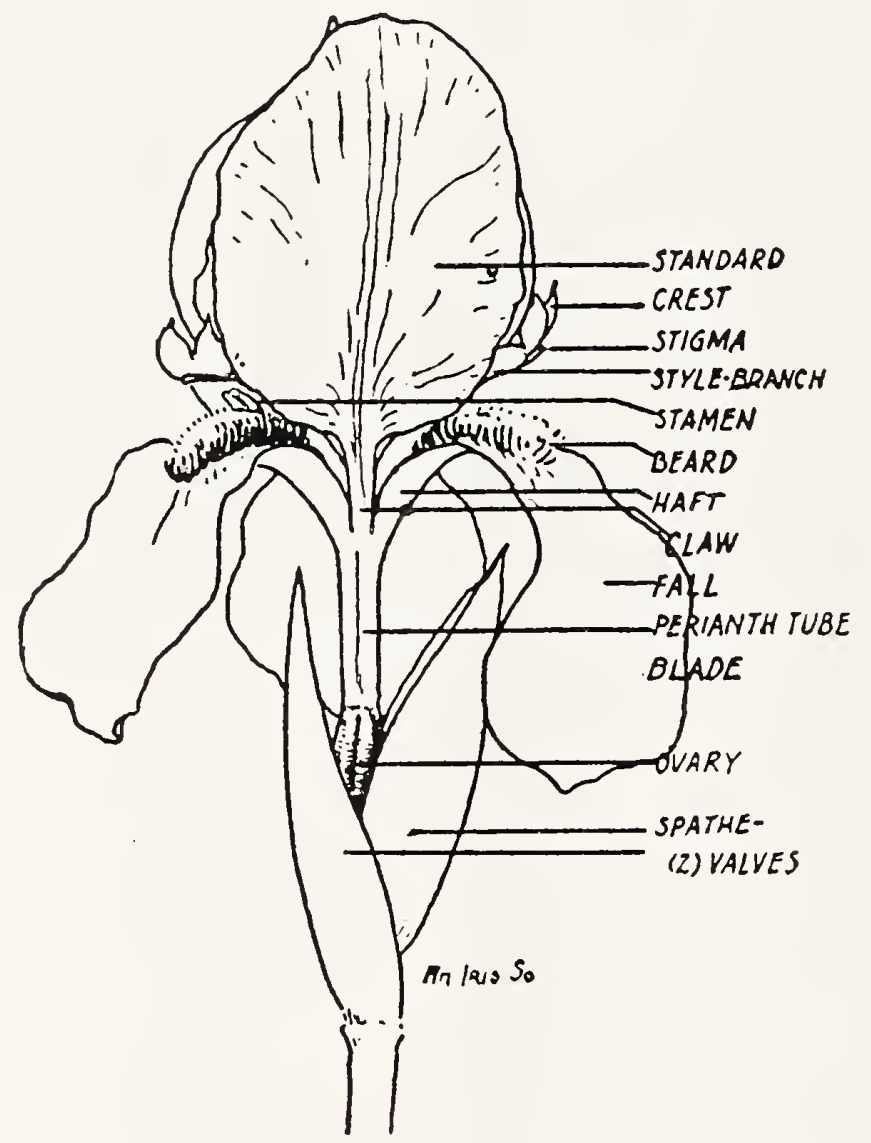

Those desiring to further increase their knowledge of the Iris are urged to join the American Iris Society, the publications and data obtained from it being of considerable value. The annual membership fee is $\$ 3.00$ and can be sent to us and we will forward it to the proper officers with our recommendations.

As you will note from the pages following, we have added practically the cream of the newer varieties of Irises from Europe and America, and including the recent seedlings of Bliss, Yeld, Hort, Wallace, Dykes, Perry, Millet and Vilmorin, which are creating such a sensation in Europe, and of Miss Sturtevant, and the Messrs. Farr, Williamson and Saunders of this country, which are also magnificent.

We have listed a number of Special Collections of Irises, etc., on page 34 of this catalogue, which will prove of considerable help, the list being composed of varieties that are beautiful and satisfactory, and guaranteed (if you are a lover of flowers), to make you an Iris enthusiast.

The varieties marked with a $\dagger$ are not for sale until after August 20th, 1922. Many of these varieties marked thus are imported and by reason of the present conditions making it difficult to import and replace we are withholding these varieties until later. See inside front cover as to time shipments of Irises are made by us. 


\title{
IRISES
}

"Oh Flower-de-luce bloom on, and let the river Linger to kiss thy feet!

Oh flower of song, bloom on, and make forever The world more fair and sweet" —Longfellow.

\section{DWARF EARLY BEARDED HYBRID CRIMEAN IRISES}

\author{
April and Early May Flowering Irises
}

These are excellent plants for permanent borderings or rockeries, growing from 6 to 18 inches high, and flower during April and May. They are very hardy, succeed in almost any soil or situation, thriving in a dry sunny location same as the Tall Bearded lrises. When planted in a double row, about four inches apart, they make a very effective edging. They can also be planted in front of the taller varieties.

Culture. Same as the Tall Bearded Iris.

1201 -Atropurpurea. S. lavender, F. purple shading lighter. Fine. $25 \mathrm{c}$.

1200 - Atroviolacea, Pumila. S. and F. purple, early. $25 \mathrm{c}$.

1202-Bridesmaid. S. white shot with pale blue; F. yellow shot with pale blue. $25 \mathrm{c}$.

1204-Coerulea, Pumila. (Wild) S. and F. sky blue. Beautiful and floriferous: early flowering. Fine for edges. $25 \mathrm{c}$.

1205-Cyanea, Pumila. (G. \& K. 1899) S. rich bright blue; F. dark satiny blue, large, handsome, good grower. $15 \mathrm{c}$.

1210-Die Fee, syn. Fairy. S. and F. pale blue, fine. $35 \mathrm{c}$.

1206-Eburna, Pumila. (G. \& K. 1899) S. ivory white; F. soft yellow shading to white, pretty. 9 in. $15 \mathrm{c}$.

1207-Excelsa. (G. \& K. 1899) Deep clear yellow with orange beard, fine, large. $20 \mathrm{c}$.

1208-Florida. (G. \& K. 1899) S. citron yellow; $F$. deeper yellow, beautifully veined. 10 in. $25 \mathrm{c}$.
1209-Formosa. (G. \& K. 1899) S. violet blue; F. violet purple with showy white beard. 18 in. $25 \mathrm{c}$

1212 -Josephine, Pumila. (Cap. 1901) Very dwarf; S. \& F. pure white, very pretty. 8 in. $25 \mathrm{c}$.

1213-Nana Alba. S. and F. white shaded blue. $25 \mathrm{c}$.

1214-Prairie Beauty. S. and F. golden. $25 \mathrm{c}$.

1217-Prairie Gem. S. and F. Orange. 25c.

$1215-$ Royal Purple, Pumila. S. and F. a handsome shade of rich purple. 12 in. $35 \mathrm{c}$

1216-Schneekuppe, Pumila. (Snow-Cup, G. and K. 1910) Large flowering, showy, pure white; falls reticulated yellow at base. $50 \mathrm{c}$.

1218-The Bride. Pure white with primrose beard. 7 in. $35 \mathrm{c}$.

(See prices on special collections on page 34.)

\section{INTERMEDIATE BEARDED IRISES}

\section{May Flowering Irises}

The lntermediate lrises comprise a new group of hybrids derived mostly from crosses between the Dwarf Crimean lrises and the Tall Bearded lrises, forming an intermediate race, both in height, and period of blooming. The flowers are very large, most beautifully colored, growing from 12 to 18 inches in height and bloom two weeks before the Tall Bearded lrises, viz.: from about May 10th to June 1 st in this latitude, thus forming a connecting link between the Dwarf Crimean Irises and the handsome Tall Bearded lrises.

Culture. Same as the Tall Bearded lrises.

801 -Barbara (Fos. 1913). Soft blue similar to coloring of Albert Victor, very pretty. 18 in. $50 \mathrm{c}$.
800 -Benacensis. S. and F. rich dark violet, early. $35 \mathrm{c}$.

834-Blue Boy (Fos. 1913). A charming lris of rich violet blue practically self-colored, even beard being blue. 18 in. $35 \mathrm{c}$.

Where, 6, 12 or more roots of one variety of lris are ordered same will be furnished at the following prices, viz.:

Varieties listed at $20 \mathrm{c}$ each are $\$ 2.00$ per doz.; at $25 \mathrm{c}$ each $\$ 2.50$ per doz.; at $35 \mathrm{c}$ each $\$ 3.50$ per doz.; at 50 c each $\$ 5.00$ per doz.; at 75 c each $\$ 7.50$ per doz.; at $\$ 1.00$ each $\$ 10.00$ per doz. Large lists of one or two of a kind will be charged at the single rate. 
802-Bride (Cap. 1901). Pure white with a primrose colored beard, large, early. $2 \mathrm{ft}$. $50 \mathrm{c}$.

803-Brunette (Cap. 1901). S. and F. primrose yellow. 18 in. $35 \mathrm{c}$.

827-Charmant (Cap. 1901). S. palest blue; F. striped dark blue. $35 \mathrm{c}$.

805-Dauphin (Cap. 1901). Rich purple with very distinct dark falls. 18 in. $35 \mathrm{c}$.

807-Dolphin (Cap. 1901). S. light blue; F. velvety, violet purple, tall, huge, handsome. 18 in. $35 \mathrm{c}$.

808-Dorothea (Cap. 1901). Porcelain white tinged with lilac. Huge and extremely handsome flower. 15 in. $35 \mathrm{c}$.

809-Eclipse (Cap. 1901). Reddish purple, very early. $35 \mathrm{c}$. $35 \mathrm{c}$

829-Empress (Cap. 1901). Creamy white.

810 -Etta (Cap. 1901). Lovely pale cream self, yellow beard. 18 in. $35 \mathrm{c}$.

811 -Freya (Cap. 1901). Porcelain gray, shaded with lilac. 18 in. $35 \mathrm{c}$.

830 -Fritzof (G. and K. 1910). S. soft lavender; $F$. soft purple, shaded lavender. Large, beautiful. $35 \mathrm{c}$.

831 -Gerda (G. \& K. 1910). S. creamy yellow; F. darker, veined yellow; large flowers. $35 \mathrm{c}$.
812-Halfdan (G. \& K. 1908). Rich creamy yellow. $2 \mathrm{ft} .35 \mathrm{c}$.

813-Helga (G. \& K. 1908). Lemon yellow with pearl shadings. Huge. $2 \mathrm{ft}$. $35 \mathrm{c}$.

815-Ingeborg (G. \& K. 1908). Very fine, pure white, immense flower. $2 \mathrm{ft}, 50 \mathrm{c}$.

816-Ivorine (Cap. 1901). Very large creamy white. 18 in. $25 \mathrm{c}$.

836-King Christian (Cap. 1901). Large sulphur white with yellow markings at base of petals. Handsome. $35 \mathrm{c}$.

819-Lurida. S. bronze crimson: F. glossy bronze maroon. Beautiful. 50c.

821 -Mars (Cap. 1901). Deep violet pur. ple, blue beard, dark foliage, very handsome and distinct. $75 \mathrm{c}$.

823-Odin (Cap. 1901). S. white dome shaped; F. lavender white, very fine form. $35 \mathrm{c}$. 832-Prince Victor (Cap. 1901). S. blue; F. violet, large flowers. $35 \mathrm{c}$.

833-Royal (Cap. 1901). Blue and violet. 12 in. $35 c$

826-Walhalla (G. \& K. 1908). S. light blue; $F$. velvety violet-purple, immense hand. some flower. 30 in. $35 \mathrm{c}$.

(See prices on special collections on page 34.)

\section{TALL BEARDED IRISES (Pogoniris)}

\section{Late May and June Flowering Irises-Fleur-de-lis}

We have one of the most complete collections of Tall Bearded lrises in this country and are continually importing new varieties. The flowers are large and exceedingly handsome and most of them deliciously fragrant and are in bloom during late May and June. Their beauty outrivals that of the Orchids in their delicacy of structure and wide range of coloring. In colors there are the richest yellows, the most intense purples, delicate blues, the softest mauves and beautiful claret-reds. There are also whites, primroses and bronzes of every shade. We are unable to express or give descriptions of the beauties of this flower. They are especially adapted for flower borders, shrubberies, woodland walks and wild gardens and for surrounding lakes and ponds. If planted around pools or lakes they should be placed well above the water level.

Fall and Spring Planting. There are distinct advantages in ordering and planting Irises both in the fall and spring. Iris roots planted in the fall will become well established and as a rule will flower well the following spring. During the following June, July and August they take on their greatest growth and increase so that the following year each of your roots will become established clumps and you should have numerous flowers-the roots of some varieties increasing more than others. If you did not plant the fall previous it is advantageous to plant in the spring, for, as a rule, if planted then you will have some flowers and your roots will become well established and increase during the months of their best development, June, July and August, resulting in well established clumps and more flowers the following year than if you had delayed until fall. Thus you can add to your collection of Irises both in the fall or spring with good results.

Culture. Any ordinary garden soil, and almost any position suits them, but a rather dry and sunny situation is the best. In wet places they are liable to decay. They object to fresh stable manure, which should be avoided when planting. As a general rule Bearded lrises like lime and when the soil requires enrichment a dressing of finely ground slaked lime or bone meal will be sufficient. They may be planted from August to November and from March to May. See time of shipment on inside page of front cover. Plant so that the top of the roots are from one to two inches below the top of the ground. (See illustrations on covers and pages following).

Where 6, 12 or more roots of one variety of Iris are ordered same will be furnished at the following prices, viz.:

Varieties listed at 20 c each are $\$ 2.00$ per doz.; at $25 \mathrm{c}$ each $\$ 2.50$ per doz.; at $35 \mathrm{c}$ each $\$ 3.50$ per doz.; at 50 c each $\$ 5.00$ per doz.: a: 75 c each $\$ 7.50$ per doz.; at $\$ 1.00$ each $\$ 10.00$ per doz. Large lists of one or two of a kind will be charged at the single rate. 


\section{LATE MAY FLOWERING IRISES}

2-Alba. Large, pure white, distinct and rare. $35 \mathrm{c}$.

3-Amas (syn. Macrantha, Col. by Fos. 1885). A handsome giant form from Asia Minor. S. rich blue; F. violet. $2 \mathrm{ft} .35 \mathrm{c}$.

4-American Black Prince. S. purple lilac; F. rich velvety black, very early. $2 \mathrm{ft}$. $25 \mathrm{c}$.

5-Argus (1877). S. and F. very dark purple, distinct. $25 \mathrm{c}$.

6 -Crimson King. Rich claret purple. 2 ft. $25 \mathrm{c}$.

7-Fontarable. S. violet blue; F. rich violet purple. $25 \mathrm{c}$.

8-Kharput (syn. Asiatica). S. violet; F. velvety violet purple; very large, handsome Hower. 30 in. $25 \mathrm{c}$.

9-Kochii. S. and F. rich claret purple; very handsome. $25 \mathrm{c}$.

10 -Major. Immense flower. S. purple blue; F. dark purple. 25c.

11 -Purple King. Full purple, very effective and handsome. $2 \mathrm{ft} .25 \mathrm{c}$.

12 -Siwas. S. violet blue; F. violet purple, gorgeous flower. 30 in. $35 \mathrm{c}$.

13-Violet Queen. S. violet blue; F. violet black. $2 \mathrm{ft} .20 \mathrm{c}$.

(See prices on special collections on page 34.)

\section{JUNE FLOWERING IRISES}

200-Atou Hassan (var. Sal. 1859). S. clear rich yellow: F. yellow mottled brown. 15 in. $20 \mathrm{c}$.

201 -Ada (var. 1887). S. bright canary yellow; F. white, ret. madder-brown. 19 in. 25 c.

524-Admiral Togo (pl.). S. pure white, penciled lavender at edge; F. ivory white. 2 f. $35 \mathrm{c}$.

202-Adonis (var. Lmn. 1840). S. deep canary; F. white, ret. brown. 22 in. 25 c.

601-A. F. Barron (sq. 1876). S. dark brown; F. veined crimson brown. 16 in. $25 \mathrm{c}$.

$\dagger 134$-Afterglow (pall. Sturt. 1918). A soft grayish lavender shading to a rich Pinard yellow through the center. Strong grower. $3 \mathrm{ft}$. $\$ 3.00$.

500-Agnes (pl. 1888). S. white, frilled and shaded lilac; F. white, traced lilac at the base or claw. $2 \mathrm{ft}$. $20 \mathrm{c}$.

602-Agnes Barr (sq.). S. lavender brown;

F. bronzy blue. 22 in. $25 \mathrm{c}$.

300-Aika (am.). S. white; F. white, base of petals blotched violet. $20 \mathrm{c}$.

401 -Albatross. S. white, shaded the palest of blue; F. white, veined and tipped rich purple. $50 \mathrm{c}$.

25-Albert Victor (pall. 1885). A great favorite. S. soft blue; F. beautiful lavender, large and beautiful flower. 25c.

700 -Albicans-see Princess of Wales.

$\dagger$ Not for sale until after August 20th 1922. (See page 5.)

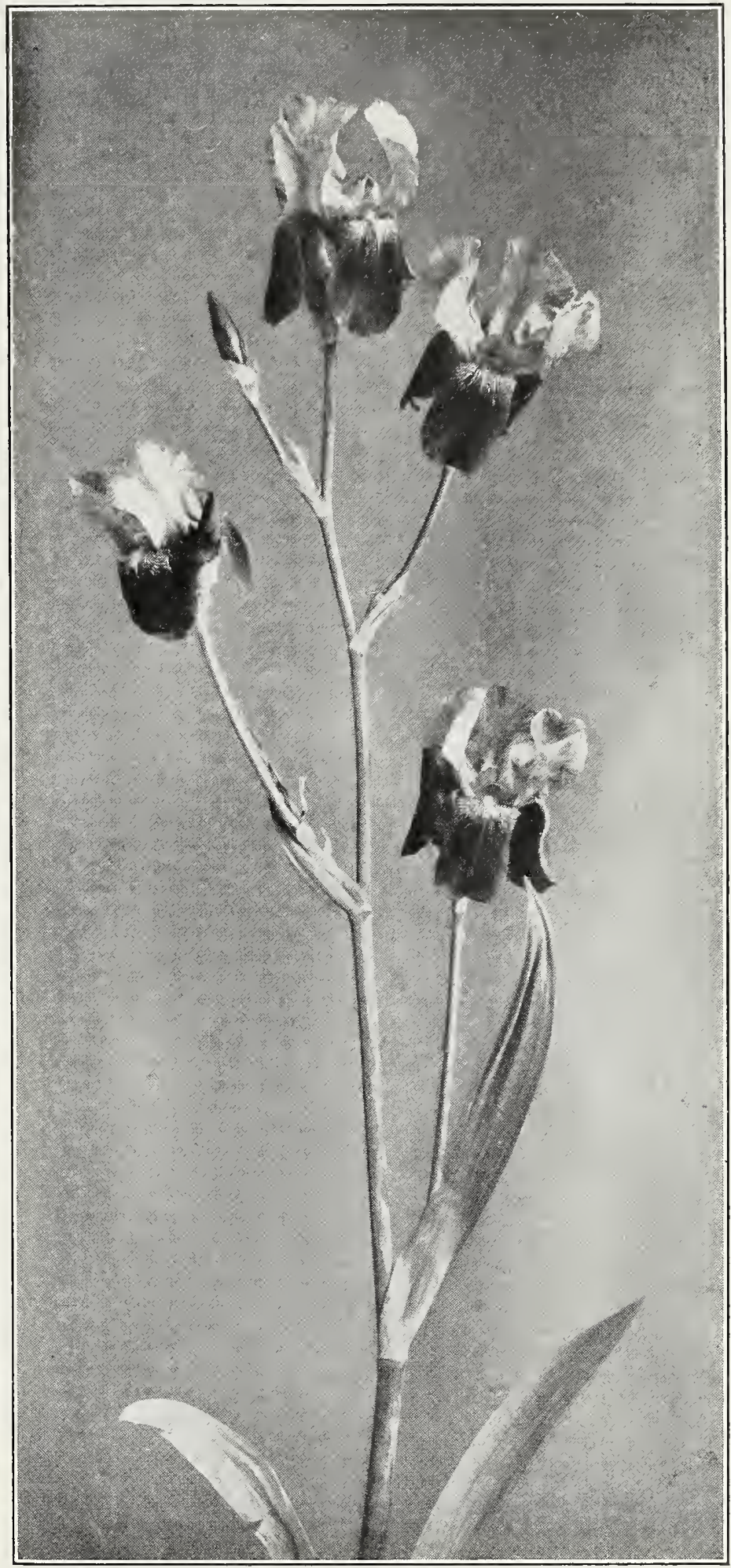

(26) Alcazar

26-Alcazar (pall. x sa. Vlm. 1910, cert. N. H.F. 1909; F. C. C., R. H. S. 1916). A giant in flower and growth. S. light bluish violet; F. deep purple, bronze veined at the throat. Very beautiful. Attracts great attention on account of its size and beauty. $4 \mathrm{ft}$. \$1.25.

400-Amabilis (syn. Laura., neg. Lmn. 1840). S. pale lilac, flushed rose: $F$. velvety crimson purple. $2 \mathrm{ft} .20 \mathrm{c}$.

†1330-Ambigu (Vilm. 1916, cert. N. H. F. 1918). A French variety of novel coloring with well formed flowers of a distinct reddish purple. 30 in. $\$ 5.00$.

(See page 4 for list of abbreviations.) 
$\uparrow 1331$-Ann Page (Hor. 1919, A. M. Chelsea 1920). Lovely pale blue self with large flowers of splendid shape. F. long, heavily penciled with brown at haft. Stem stout and erect. One of Hort's best and the finest of the pale purple varieties. $36 \mathrm{in.} \$ 15.00$.

526-Anna Farr (pl. Farr 1913). S. white, lightly bordered pale blue; F. pure white with pale blue markings at the base. Large flower, beautiful. 36 in. $\$ 2.50$.

$\dagger 331$ - Anne Leslie (am. Sturt. 1918. A. M., M. H. S. 1916). S. white, rose tinted; F. dahlia carmine, orange beard. 27 in. $\$ 2.00$.

27-Archeveque (syn. Archbishop, pall. Vilm. 1911, C., R. H. S. 1916). S. rich purple violet; F. deepest velvety violet; extremely rich coloring. A rare and very beautiful flower, late flowering. $2 \mathrm{ft}$. $\$ 1.50$.

402-Ardenta (neg.). S. pale lavender; F. dark violet blue, ret. white at claw. $25 \mathrm{c}$.

603 -Arnols (sq. Barr). S. rosy bronze; F. rich velvety purple. Handsome. 30 in. $25 \mathrm{c}$.

$\uparrow 1332$-Asia (Yeld., A. M. 1916). A grand importation unlike anything in cultivation with unusually large flowers and fine bold upstanding foliage. S. broad and massive pale silvery lavender, deepening at the base to yellow and gold; F. pale reddish purple lightening in color toward the margin. Beard bright golden yellow. The whole effect of the flower is unusual and stands out as one of the finest Irises introduced. On account of the large flowers and massive spike, to safeguard from winds, it is well to stake the individual spikes. $4 \frac{1}{2} \mathrm{ft} . \quad \$ 25.00$.

28-Assuerus (syn. Assurez, pall. Lmn.). S. bright violet; F. crimson purple. Handsome. A good reddish variety. 26 in. $25 \mathrm{c}$.

529-Assyrie (pl.). S. and F. white, penciled and suffused with blue. $35 \mathrm{c}$.

$\dagger 272$-Athene (Sturt. 1920). A warm white, haft and claw finely ret. maroon on cream; beard lemon yellow, style branches light buff yellow on the sides. Strong grower, handsome. 33 in. $\$ 3.00$.

404-Atrocoerulea (neg.) S. pale blue; F. violet blue. $25 \mathrm{c}$.

403-Attraction (neg. 1885). S. pale blue; F. violet blue, shaded lighter at base. $25 \mathrm{c}$.

203-Aurea (var., Jac. 1830, H. C., R. H. S. 1916). S. and F. rich chrome yellow. This variety, Mrs. Neubronner and Sherwin Wright are the three most popular self yellows. $2 \mathrm{ft}$. $25 \mathrm{c}$.

31-Aurora (pall., Fos. 1909). A very tall Iris with pale lavender pink shaded flowers and orange beard. Handsome. $3.4 \mathrm{ft} .75 \mathrm{c}$.

32-Australis (pall.). S. deep lavender; F. light blue. Very tall, large and handsome. 3-4 ft. $25 \mathrm{c}$.

662-Aviator (sq., Perry 1919). S. bronze; F. white flushed violet. $\$ 1.00$.

$\uparrow 1300$-Azure (Bliss 1918). S. lavenderblue; F. broad rich violet blue, perfect in color tone. A delightful seedling and beautiful on account of its clear and intense coloring. $\$ 4.00$.

$\uparrow$ Not for sale until after August 20th, 1922.

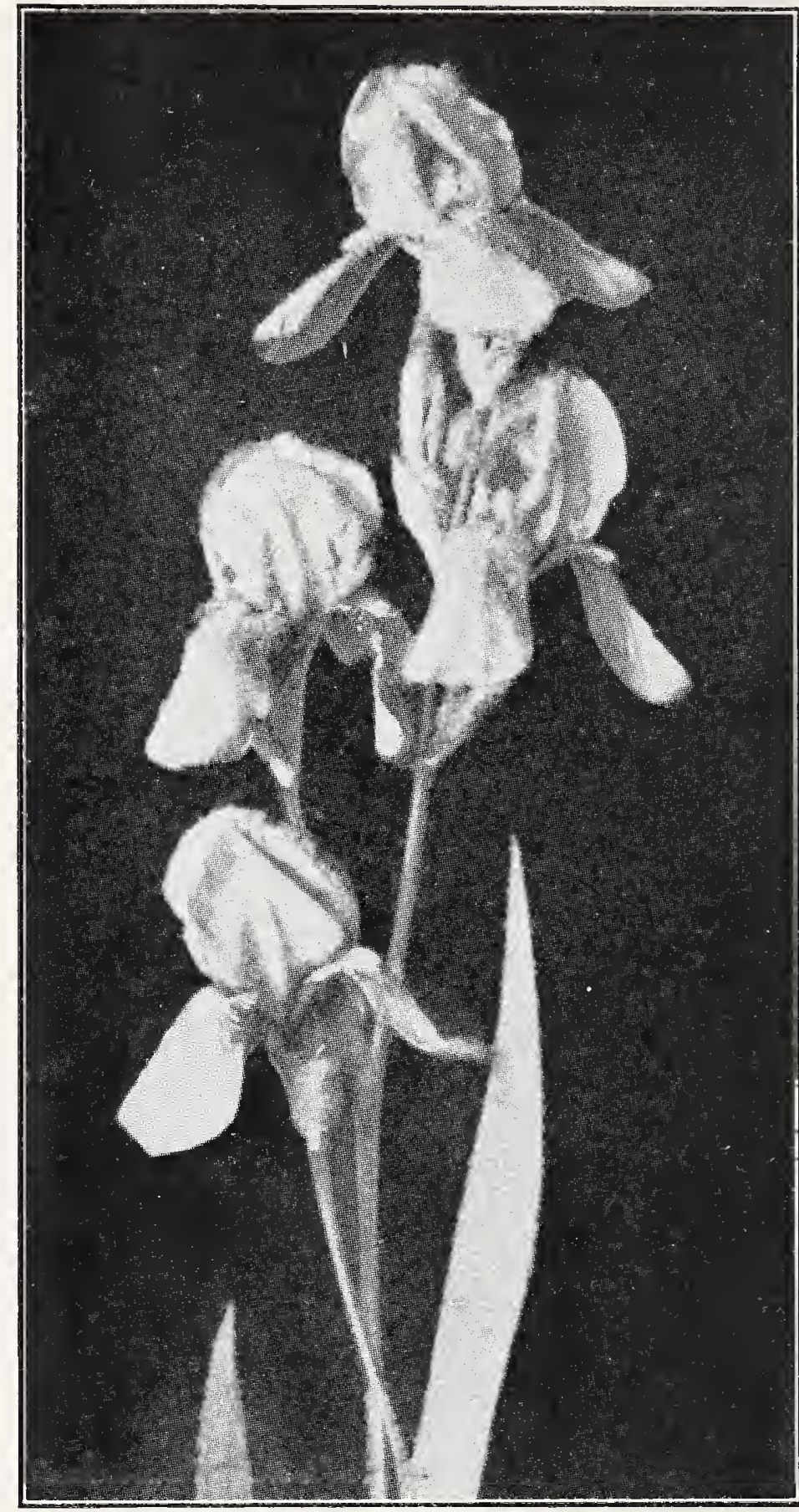

Ann Page

709-Baxter (syn. Flavescens Baxteri). S. deep chrome yellow; F. pale primrose yellow. $2 \mathrm{ft}$. $25 \mathrm{c}$.

502-Bariensis.-See Buriensis.

205-Beaconsfield (var). S. yellow; $F$. crimson, edged primrose. $2 \mathrm{ft}$. $25 \mathrm{c}$.

504 -Beauty (pl.). White, edged blue. $25 \mathrm{c}$.

253-Berchta (var., G. \& K. 1909). S. bronzy yellow; F. blue-violet, bordered bronze. Pretty. $35 \mathrm{c}$.

143-Bluebeard (pall.). S. and F. an even blue, no other shade. One of the best blues. $25 \mathrm{c}$.

$\uparrow 1301$-Blue Bird (Bliss 1919). Self-colored flowers of the brightest blue. F. at right angles to the S. Very unusual type on account of its intense blue coloring. 30 in. $\$ 5.00$.

444-Blue Jay (neg. Farr 1913). S. bright clear blue; F. intense dark blue. 30 in. $35 \mathrm{c}$.

(See page 5.) 
406-Boccage (neg. Lmn. 1840). Clear purple, reticulated white. $25 \mathrm{c}$.

$\uparrow 135$-Brandywine (pall. Farr 1920). S. and F. pale silvery blue; distinct orange beard. General color effect is clear blue. In some respects, similar to Crusader, but pronounced by many to be superior. $\$ 5.00$.

505-Bridesmaid (pl. Sal. 1859). S. white, shaded silvery lilac; $F$. reticulated at base, slightly frilled soft lilac. $25 \mathrm{c}$.

33-Brionense (pall.). Pale violet; very free flowering, large, handsome. $2 \mathrm{ft} .25 \mathrm{c}$.

407-Britannicus (neg. 1864). S. pale lavender; F. light blue. $20 \mathrm{c}$.

606-Bronze Beauty (sq. 1884). S. clouded yellow; F. ruby lavender, golden crest. 28 in. $25 \mathrm{c}$.

144-Brooklyn. S. pearl gray with faintest flush of yellow: F. soft lavender. Large, of very delicate coloring. $25 \mathrm{c}$.

502-Buriensis (syn. Bariensis, pl., De B. 1820). Delicately edged and dotted pale lilac rose. $25 \mathrm{c}$.

531 -Buriensis Elizabeth (pl.). S. white, heavily shaded lilac; F. white, shaded violet at margin. $25 \mathrm{c}$.

$\nmid 29-B$. Y. Morrison (pall., Sturt. 1918, F. C. C., M. H. S. 1915). S. pale lavender-violet; F. velvety raisin-purple with broad lavender border. Distinct and very handsome. $\$ 2.50$. 408-Cameleon (syn. Wm. Wallace, neg., Lmn. 1840). Brilliant blue shaded violet. $25 \mathrm{c}$. $\uparrow 1302$-Camelot (Bliss 1918). A forerunner of many new seedlings of the Madam Chereau type; spikes $4 \mathrm{ft}$. high and branching; $\mathrm{S}$. and F. creamy white, edged with pale violet. Very attractive. $\$ 4.00$.

303-Calypso (am. Lmn. 1840). S. white; F. white ret. blue. 18 in. Pretty. $25 \mathrm{c}$. $20 \mathrm{c}$.

409-Candicans (neg.). Soft light blue.

34-Caprice (pall., Vilm. 1904). S. reddish purple; $F$. deeper and richer. A good wine red Iris. Large and handsome. $3 \mathrm{ft}$. $50 \mathrm{c}$.

702-Carthusian (Mar. 1906). Handsome hybrid. S. clear lavender-blue; F. darker blue, ret. brown at claw; large and fragrant. $2 \mathrm{ft}$. $\$ 2.00$.

35-Caterina (cyp. x pall., Fos. A. M., R. H. S. 1907). Massive lavender flowers on $4 \mathrm{ft}$. high flexuous stems, the same colored flower as P. Dalmatica but larger and more noticably veined at the throat. Very beautiful. $\$ 1.00$.

36-Celeste (pall., Lmn. 1858). Pale azure blue, large flower. Pretty. $25 \mathrm{c}$.

37-Celia (pall. $x$ ceng., Wallace). Soft rosy-mauve, early flowering, very pretty. 30 in. $75 \mathrm{c}$.

703-Cengialti (Ambrosi). Clear blue flowers, very fragrant. Free bloomer. 18 in. 35c:

38-Cherubin (pall., Vilm. 1911). A pale edition of Her Majesty. S. very pale lilac; $F$. pale lilac thinly veined with purple. Beautiful. $50 \mathrm{c}$.

208-Chelles (var.). S. bright golden yellow; F. bright red purple, beautifully ret.; choice. $25 \mathrm{c}$.

$\dagger$ Not for sale until after August 20th, 1922.
39-Chester Hunt (pall. x neg., Farr 1913). S. celestial blue; F. dark marine blue, bordered pale blue shading at base; stigmas light blue. 27 in. $75 \mathrm{c}$.

$\dagger 40$-Clara Curtis (cyp. x pall., Per. 1911). Charming hybrid. S. broad, clear heliotrope; F. rosy purple conspicuously netted bronze on white ground, golden yellow crest. $\$ 2.00$.

411 -Clarissima (neg.). S. lavender; F. ret. purple, on white ground. 24 in. $25 \mathrm{c}$.

$\uparrow 1303$-Clematis (Bliss 1917). Unique. Shaped like an exceptionally fine Japanese Iris or a large six petaled Clematis. All six segments of the flower reflects horizontally. Color light clear violet with variable veining at base. Strong grower, free flowering and fragrant. 30 in. $\$ 7.50$.

410 -Clio (neg. 1863). S. lavender; shad. ed white; F. rich purple edged white. Pretty. $35 \mathrm{c}$.

305-Conqueror (syn. Conqueror of Europe am., Lmn. 1840). Bluish white $S$. with velvety purple F. $25 \mathrm{c}$.

41 -Contraste (pall.). S. light blue; F. dark black blue. $35 \mathrm{c}$.

304-Comte de St. Clair (am.). S. white; F. deep violet with white margin. Pretty. 2 ft. $25 \mathrm{c}$.

414-Cordelia (neg., Park. 1873). S. rosy lilac; F. rich crimson purple, handsome, flor. ferous, late flowering. $75 \mathrm{c}$.

413 -Cottage Maid (neg., Barr). S. silvery blue; F. white, tipped and ret. violet. $25 \mathrm{c}$.

†1304-Cretonne (Bliss 1919). S. pale bronze-purple; F. rich red maroon with striking orange beard. The spathes and stem are also colored a reddish brown and the whole plant presents a very striking appearance. The deep-reddish purple tone, lit up by the orange beard, at once attracts attention. Strong grower, branching stems. $3 \mathrm{ft}$. $\$ 7.50$.

42-Crusader (pall., Fos. 1913, H. C., N. H. F. 1916). The boldest of the clear blues and richest seedling of the late Sir Michael Foster. Very large broad petaled, stout textured flowers. S. a light shade and F. a deep shape of violet blue, beard orange yellow. Splendid color. One of the most beautiful of all lrises. 42 in. $\$ 3.00$.

415-Cythere (neg. 1869). S. fine lavender blue: F. rich blue, late flowering. $2 \mathrm{ft}$. $25 \mathrm{c}$.

$\dagger 324$-Dalila (am., Den. 1914, Cert., N. H. F. 1920). S. palest flesh white; F. rich red purple; yellow beard. One of the most distinctive and striking. $\$ 2.00$.

43-Dalmarius (G. \& K. 1907, H. C., R. H. S. 1916). A cross between Dalmatica and Darius. S. dark blue; F. violet brown. Large and handsome. $25 \mathrm{c}$.

$\dagger 1305-D a p h n e(B l i s s$ 1920). S. pure white; F. large spreading, heavily ret. purple on a white ground, deepening to a rich purple below, with a distinct white margin. A greatly improved Rhein Nixe. The color and shape of the F. contrasting finely with the pure white

(See page 5.) 
of the S. A lovely plant and one of Bliss' handsomest seedlings. $\$ 7.50$.

254-Dawn (var., Yeld 1911, C., R. H. S. 1916). A beautiful sulphur yellow Iris, bronzed veined at the throat, the bright orange beard and soft amber shading at the throat, at once distinguishing this from Flavescens. $2 \mathrm{ft}$. $\$ 2.00$.

212 -Darius (var. Park 1873, H. C., R. H. S. 1916). S. canary yellow; F. lilac, margined white; rich orange beard, distinct and very beautiful. $25 \mathrm{c}$.

44-Delicata (pall.). S. pale lavender; F. white, delicately traced and tipped lavender. Pretty. 20c.

506-Delicatissima (pl.). White, heavily frilled blue. $2 \mathrm{ft}$. $25 \mathrm{c}$.

$\dagger 530$-Demi-Deuil (pl., Den. 1912). S. amber yellow, heavily veined and dotted deep livid purple; F. white, veined and dotted dark dull purple. A dark plicata of unusual color. $\$ 1.00$.

$\uparrow 1306$-Diadem (Bliss 1919). S. pale mauve; F. deep reddish mauve, with brilliant orange beard. Strong grower, stout stems. Very striking plant and most effective massed by itself. $3 \mathrm{ft}$. $\$ 4.00$.

$\dagger 1307$-Dimity (Bliss 1919). S. white, slightly veined and penciled mauve; F. wide, long and spreading of fine shape, faintly veined with lavender towards the upper half. Very decorative as a cut flower. Strong grower, tall branching spike. $3 \mathrm{ft}$. $\$ 6.00$.

$\dagger 1309$-Dominion (Bliss 1917, A. M., R. H. 5.). A wonderful Iris and the forerunner of a new race on account of the extraordinary development of the F. S. Dauphin's blue or lighi bluish-violet, large, erectly held, well developed and slightly veined. F. of exceptional substance broadening out at the base to a deep rich indigo-purple velvet, veining in the throat, violet purple on white ground. Beard orange, very pronounced. Strong and vigorous, foliage very broad and blue green. Considered the finest Iris in cultivation. Stock limited. $\$ 40.00$.

306-Donna Maria (am., Lmn. 1840). S. white; F. white, tinged lilac. Beautiful. $25 \mathrm{c}$.

$\$ 45$-Donna Nook (Perry). Stout, well branched stems bearing 8-12 enormous flowers; S. glorious shade of dark lavender blue; F. broad, standing at right angles, bright purple shaded lavender, reticulated white and brown. $\$ 3.00$.

$\uparrow 1308$-Dora Longden (sq., Bliss 1918). S pale lavender suffused with yellow; F. rich red lilac suffused at haft and edged with yellow. A very richly colored lris. Strong grower, very free flowering. $\$ 5.00$.

610-Dr. Bernice (sq. 1867, C., R. H. S. 1916). S. coppery bronze; F. velvety crimson. Very large and handsome. $35 \mathrm{c}$.

$\$ 1310$-Drake (Bliss 1919). On the lines of P. Dalmatica with well shaped flowers of the palest Cambridge blue. Very free flowering. $3 \mathrm{ft} . \$ 6.00$.

$\dagger$ Not for sale until after August 20th, 1922.

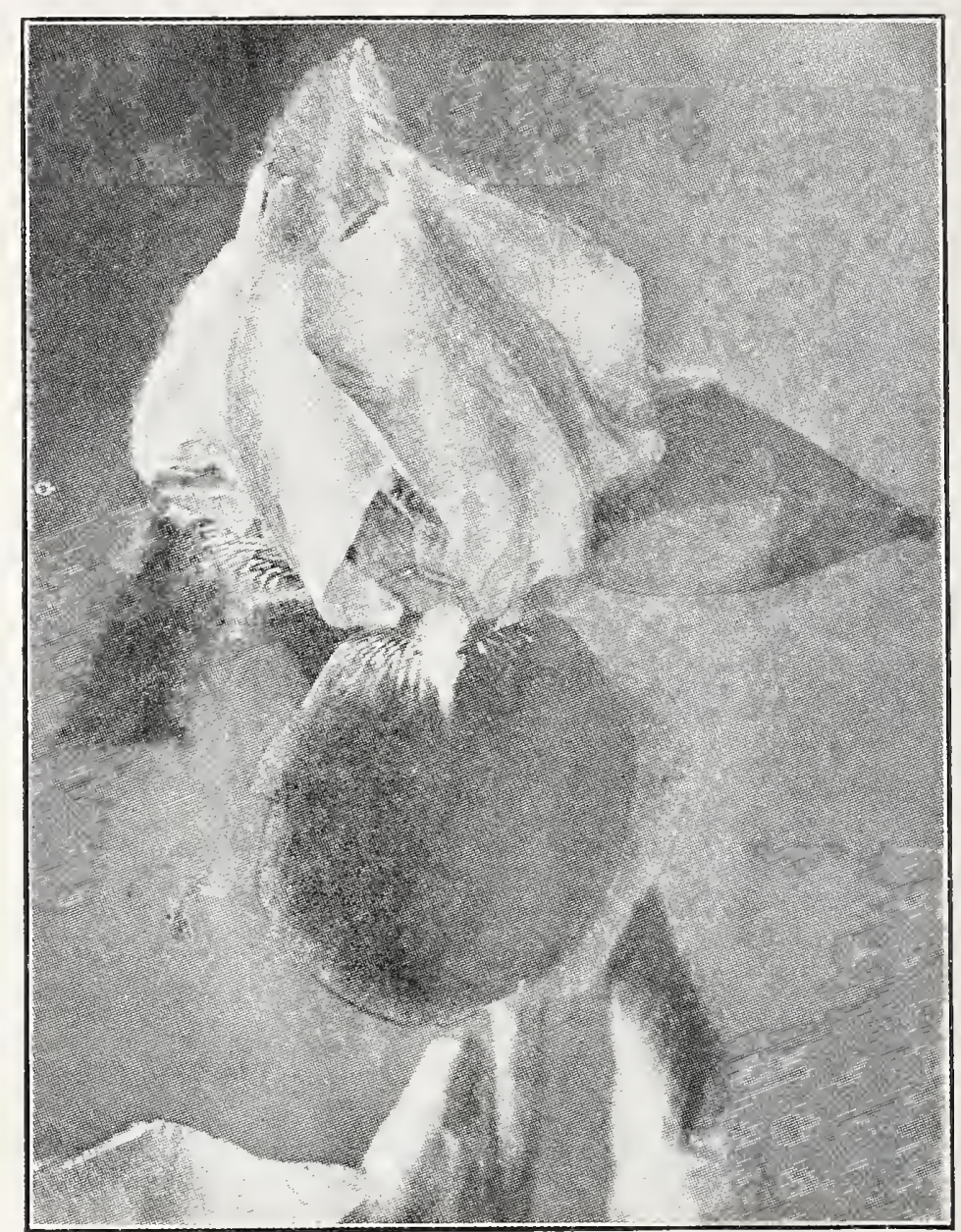

Dominion

416-Du Bois de Milan (neg.). S. lavender; F. crimson purple, ret. white. 26 in. 25 c.

309-Duchess of Wellington.-See Reticulata.

$\$ 1311$-Dusky Maid (Bliss 1919). Very similar in coloring to Mrs. Cowley, but a stronger grower. S. pale buff; F. large, wide, spreading, of a deep mauve-purple with pale broad margin, heavily ret. at haft. Fine. 30 in, $\$ 5.00$.

446-Edith (neg.). S. pale lavender; F. purple, strong grower; fine for massing. $25 \mathrm{c}$.

$\uparrow 47$-Edouard Michel (pall., Verd. 1904, Cert. N. H. F. 1905, M., R. H. S. 1916). S. broad and frilled; the falls of great width, self colored flowers of distinct deep wine red, an improvement on Caprice. $3 \mathrm{ft}$. $\$ 2.00$.

46-Edward VII (pall. Perry). S. blue; F. bright reddish violet, fine for cutting. 32 in. $75 \mathrm{c}$.

213-Edward Simmons (var. 1889). S. yellow, flaked purple; F. dark velvety violet; late flowering. 26 in. $25 \mathrm{c}$.

$\dagger 1312$-E. H. Jenkins (Bliss 1919). An exceptionally fine plant, strong grower, stout branching stems. Very free flowering. Sometimes up to fifty blooms on one plant. $S$. of the palest-purple: F. of a deeper shade. 45 in. $\$ 10.00$.

\section{(See page 17.)}


647-Eldorado (sq., Vilm. 1910, Cert., N. H. F. 1909; A. M., R. H. S. 1916). S. yellowish-bronze shaded beautifully with heliotrope; F。 bright violet-purple, center of flower golden yellow. A rich color combination. 30 in. $\$ 1.00$.

332-Elegans (am. Vidonne). S. nearly white dashed and splashed with violet; $F$. violet, veined white. Pretty. $25 \mathrm{c}$.

520-E. L. Crandall (pl., Farr 1915). S pure white; F. white heavily bordered deep blue at the base. $75 \mathrm{c}$.

†1334-Emir (Yeld 1918). S. pale blue; F. very dark purple-blue. Tall vigorous, free flowering. $\$ 5.00$.

48-Erich (pall., Farr 1913). S. bright, light violet, flushed rose; F. bright violet-purple, large; wide S. and F.; fragrant. $3 \mathrm{ft}$. $50 \mathrm{c}$.

310-Eugene Sue (am., Lmn. 1848). S. white; F. creamy white with purple spots and stripes. $25 \mathrm{c}$.

507-Fairy (pl. Kem. 1905). White, delicately suffused soft blue, a beautiful variety. $25 \mathrm{c}$.

420-Fairy Queen (neg., Sal. 1859). S. and F, white striped blue. $25 \mathrm{c}$.

708-Flavescens. A delicate shade of soft yellow; large sweet scented, fine for massing. Early. 30 in. $20 \mathrm{c}$.

421 -Florence Barr (neg., Barr 1876). S and $F$. blush rose lilac. $25 \mathrm{c}$.

711 -Florentina (lntr. N. Europe 1500, H. C., R. H. S. 1916). Creamy white, flushed lavender; very early and fragrant. Excellent cut flower. $2 \mathrm{ft}$. $20 \mathrm{c}$.

712-Florentina Silver King. Pure white flowers and much larger than Florentina. 25c

255-Foster's Yellow (var., Fos. 1909). A creamy yellow, between Flavescens and Aurea. Handsome. $35 \mathrm{c}$.

$\dagger 1313$-Francina (pl. Bliss 1920). Madam Chereau type, tall, slender, well shaped flower. S. spotted and heavily veined with reddish-pur ple; F. edged with same color. One of the most novel and distinct of its type. $3 \mathrm{ft}$. $\$ 7.50$.

419-Frederick (neg. 1896). S. pale lavender; F. lavender barred with brown; free flowering, fine for massing. 25c.

268-Fro. (var., G. \& K. 1910). S. deep gold; F. brilliant chestnut-brown with narrow border of gold. This takes the place of and is far superior to Honorabile. Beautiful. 50c.

215-Gajus (var., G. \& K. 1906, A. M. R. H. S. 1916). S. light yellow; F. crimson var., reticulated white and yellow picotte edge. A striking handsome variety. $35 \mathrm{c}$.

216-Ganymede (var., Lmn. 1855-8). yellow; F. white, ret. maroon, attractive. 21 in. $20 \mathrm{c}$.

49-Garibaldi (pall., Ware 1898). Fine rosy pink. Very attractive and fragrant. $2 \mathrm{ft}$. $25 \mathrm{c}$

503-Gisele (syn. Gazelle, Bleu Parfleur; pl., Lmn. 1848). White, heavily fringed rich mauve. 28 in. $35 \mathrm{c}$.

$\dagger$ Not for sale until after August 20th, 1922.
†136-Georgia (pall. Farr. 1920). S. and F. and stigmas soft shade of uniform cattleya-rose, bright orange beard. A delicate and beautiful variety. $\$ 2.50$.

$\dagger 1335$-Geraldine (Yeld 1911). S. white tinged lavender; F. richly ret. purple on a white ground, very bright orange beard. 30 in. $\$ 4.00$.

50 -Gloire de Hillegom (pall., Dutch). S. and $F$. clear light blue; a fine variety. 35c.

311 -Gloriette (am., Lmn. 1855-8). S. white; F. white, traced purple. Very effective. 20 c.

51 -Glory of Reading (pall., Farr 1909). S. deep blue; $F$. deep royal purple, conspicuous orange beard. Large, handsome, fragrant. $50 \mathrm{c}$.

52 -Gold Crest (pall., Dykes 1914, A. M., R. H. S. 1914). Bright violet blue of a delightful self-color and unveined, with conspicuous golden-yellow beard which gives it its name. Very large and handsome. 36 in. \$2.00.

648-Goliath (sq. Cay. 1908). Similar to Prosper Laugier, but F. are deep purple instead of crimson, and S. a pale bronze. $\$ 1.50$.

218 -Gracchus (var., Ware 1884-7). S. yellow; F. crimson ret. white, early. Very fine. 18 in. $20 \mathrm{c}$.

$\dagger 53$-Grand Bouquet (pall., Per. 1919). S. clear lavender rose; F. brilliant rose claret, a distinct striking variety. $\$ 1.50$.

54-Grandiflora (pall.). S. \& F. violet purple. Late flowering, large, beautiful. 35c.

329-Grand Master (am., Per.). S. white: F. dark blue, edged white; very pretty. $\$ 1.50$.

†1314-Gules (Bliss 1917, C., R. H. S. 1916). A distinct bicolor. F. of rich pansy-dash violet of enamel-like smoothness. The haft has brown veining on cream ground. S. pale lilac shot with red. Tall branching, strong grower, free flowering. 36 in. $\$ 4.00$

614-Gypsy Queen (sq., Sal. 1859). S. old gold, shaded pearl; F. black, maroon ret. light yellow; late. $2 \mathrm{ft}$. $20 \mathrm{c}$.

422-Hannibal (neg. 1884). S. lavender; F. dark purple. Pretty. 20c.

615-Harrison Weir (sq., Weir 1880). S. yellow bronze; $F$. velvety crimson. 22 in. $20 \mathrm{c}$

79-Haydee (syn. Haydn; pall. 1854). S. pink, deeper than in Queen of May; $F$. rose lilac, darker at the center, orange beard; excellent as a midseason pink. $35 \mathrm{c}$.

508-Hebe (pl. 1854). White, suffused soft blue. $35 \mathrm{c}$.

219-Hector (var.). S. soft clouded yellow; F. velvety crimson black. Attractive. 30 in. $20 \mathrm{c}$.

55-Her Majesty (pall., Per. 1903, C., R. H. S. 1916). S. rose pink; $F$. bright crimson tinged a darker shade; a beautiful pink variety. 30 in. $35 \mathrm{c}$.

$\uparrow 1336$-Hermione (Hort 1920). A late flowering purple bicolor, strong, massive foliage. S. bright blue-purple; F. very distinct, rich reddish-purple with orange beard, ret. brown at haft. $\$ 6.00$.

(See page 5.) 


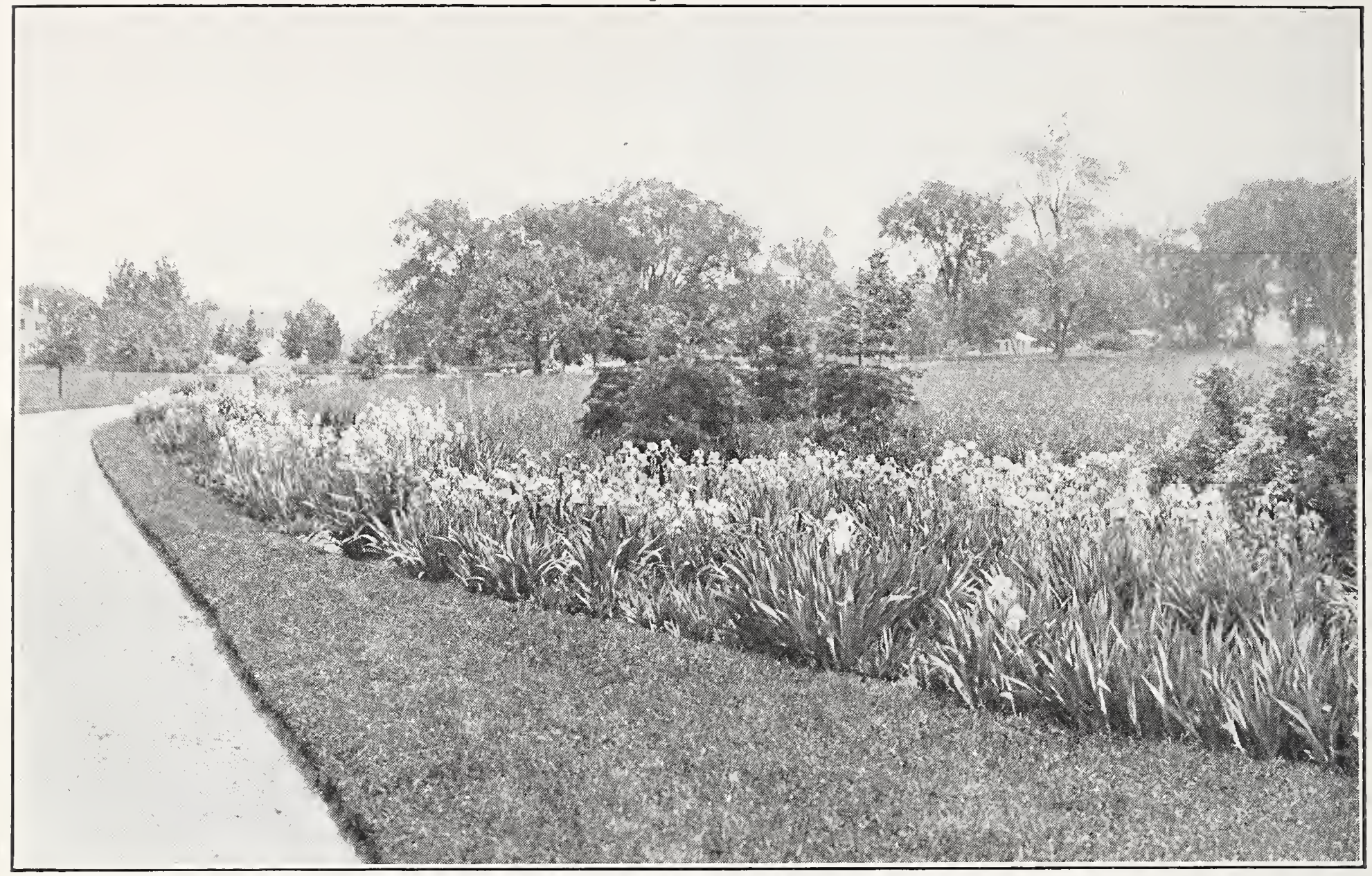

A Charming Iris Border

448-Hiawatha (neg., Farr 1913). S. pale lavender, flushed rose; F. royal purple, bordered lavender. 28 in. $75 \mathrm{c}$.

†137-Hope (Sturt. 1918, H. M., M. H. S.). Faint pinkish lilac sparsely veined on the falls. 33 in. $\$ 1.00$.

57-Hugo (pall., Farr 1913). S. petuniaviolet; F. deep purple, wide spreading flowers. Very large, handsome. 23 in. $50 \mathrm{c}$.

423-Ignacite (syn. Ignatia, neg., Lmr. 1859). S. and F. mauve. $25 \mathrm{c}$.

652-Incognita (sq., Fos. 1909). S. pale pinkish bronze; F. deep crimson, a small Prosper Laugier. $75 \mathrm{c}$.

222 -Innocenza (var., Lmn. 1854). S. and F. ivory white, crest rich golden; a very delicate and showy flower. 26 in. $25 \mathrm{c}$.

223-Iris King (var., G. \& K. 1907, A. M.. R. H. S. 1916). S. clear lemon yellow; F. rich maroon, bordered yellow, brilliant large flowers; handsome. $50 \mathrm{c}$.

646-Iroquois (sq., Farr 1909). S. smoky lavender dotted brown; F. black, maroon ret. white at base. Tall; very attractive. $35 \mathrm{c}$.

59-Isoline (pall., Vilm. 1904, cert., N. H. F. 1908, A. M., R. H. S. 1916). A grand distinct Iris, large stout textured flowers and bold foliage; S. lilac pink; F. purplish old rose golden at the throat, yellow beard. $3 \mathrm{ft}$. $\$ 1.00$.

$\uparrow 1337$-Ivanhoe (Mil. 1911). A very pretty variety with flowers of fine form of a smoky pale blue. Very decorative. 30 in. $\$ 5.00$.

+ Not for sale until after August 20th, 1922.
617-Jacquesiana (sq., Lmn. 1840, H. C., R. H. S. 1916). S. bright coppery crimson; F. rich maroon, beautiful. 30 in. $50 \mathrm{c}$.

58-James Boyd (pall., Farr 1915). S. immense, broad, incurved, forming a high dome shape center; clear light blue; F. dark violet tipped and edged lighter. Handsome. 30 in. $50 \mathrm{c}$.

618-Jean Sisley (sq. 1887).

S. crimson bronze; F. crimson. 26 in. 20 c.

528-Jeanne d'Arc (pl., Verd. 1907). White, frilled lilac. A beautiful plicata. $35 \mathrm{c}$.

80-Jordaens (syn. Jordan, pall. 1862). S. and F. excellent lilac-pink deeper than in Queen of May or Mrs. Alan Gray, with a beautiful shade of blue in the inner petals. $27 \mathrm{in} .50 \mathrm{c}$.

225_Jules Perot (var.). S. bronzy yellow; F. black maroon, ret. yellow. Pretty. 25 c.

226-Juliette (var.). S. bright yellow; F. yellow tipped and veined mahogany. $35 \mathrm{c}$.

227-Julius Caesar (var.). S. yellow; F. brownish stained. Pretty. $25 \mathrm{c}$.

325-Jungfrau (am.). S. white; F. white, striped blue. $2 \mathrm{ft}$. $25 \mathrm{c}$.

61 -Juniata (pall., Farr 1909). S. and F. beautiful clear blue, deeper than Dalmatica. Huge, sweet scented flowers. 44 in. $50 \mathrm{c}$.

723-Junonia. A new species from the East of exceptionally strong growth. Spikes 4-5 feet high. Massive flowers. F. violet purple; S. soft blue. One of the largest bearded species known. $\$ 3.00$.

(See page 5.) 
620-Justinian (sq.). S. violet bronze; F. black maroon, ret. white. Pretty. $25 \mathrm{c}$.

714-Kashmiriana (Miss Willmott). White, slightly washed lavender. Petals of a stout, leathery texture; F. at right angles. Tall. $\$ 1.00$.

$\dagger 724$-Kashmir White (Fos. 1913, A. M., R H. S.). Most beautiful of white hybrids. Stems 4 feet high and carry six large pure white flowers. Floriferous. $\$ 10.00$.

62 -Kathleen (pall.). S. and F. soft rose lilac. A large handsome flower. 50c.

63-Khedive (pall. 1884). A beautiful soft lavender with distinct orange beard. Tall, large. 33 in. $20 \mathrm{c}$.

†1316-Knysna (Bliss 1917). A very fine variety, exceedingly free-flowering and vigorous grower. Long arching $\mathrm{S}$. of clear deep yellow; F. a deep velvety red-brown. The finest yellow variety in cultivation. 33 in. $\$ 5.00$.

621 -Kochosum (sq.). S. bronzy yellow; F. yellow flushed lavender, heavily veined brown. Distinct. $25 \mathrm{c}$.

64-L'Africain. S. rose purple; F. purple striped white. 27 in. $25 \mathrm{c}$.

67-Lady Foster (pall., Fos. 1913, A. M., R. H. S. 1916). Flowers unusually large, smooth and stout textured, splendid bold erect habit. S. pale blue; F. light bluish violet, veined old gold at the broad throat. 42 in. $\$ 5.00$.

622 -Lady Jane (sq.). S. coppery rose; F. madder red, ret。 white. Pretty. 30 in. $25 \mathrm{c}$.

$\lceil 632$-Lady Jellicoe (Perry). S. a beautiful shade of silver grey; F. madder crimson, brilliant orange crest. $\$ 3.00$.

623-Lady Seymour (sq.). S. lavender, flushed sulphur; F. netted violet and white. 25 in. $20 \mathrm{c}$.

†1315-Lancelot (Bliss 1919). Tall, with stout stems, bearing well shaped, self colored flowers of pale, rosy-mauve, with bright orange beard. Very distinctive. 36 in. $\$ 5.00$.

449-La Neige (Verd. 1912, cert., N. H. F. 1914). A pure wax white without throat linirgs. Beard clear yellow. $\$ 2.50$.

626-La Prestigieuse (sq.). S. bronzy yellow; F. purplish plum veined white. $25 \mathrm{c}$.

68-La Tendresse (pall.). Large flowers, clear lavender-blue; tall grower, similar to Australis. $25 \mathrm{c}$.

229-Laurentinus (var.). S. yellow; F. yellow, netted purple. $25 \mathrm{c}$.

424-Lavater (neg. 1884). S. lavender, veined purple; F. white, traced and tipped violet. $2 \mathrm{ft}$. $20 \mathrm{c}$.

625 -Lavendulacea (1884).

white; F. lavender. 28 in. $25 \mathrm{c}$.

66 - La Reve (pall., Perry).

S. creamy

S. clouded rose; $F$. white flushed rose. $75 \mathrm{c}$.

†1339-Leander (Bliss 1920). A showy variety with well shaped reddish-violet selfcolored flowers of an unusual shade. 30 in. $\$ 2.50$.

517-Leda (pl., Farr 1909). S. white, frilled and dotted rose lilac; $F$. white. Beautiful. $2 \mathrm{ft}$. $50 \mathrm{c}$.

$\dagger$ Not for sale until after August 20th, 1922.
312-Lemon (am., Lmn. 1840). White spotted with purple, deep purple stripe. Handsome. $2 \mathrm{ft}$. $50 \mathrm{c}$.

+131 -Lent A Williamson (Wmsn. 1918). S. campanula-violet; F. rich royal purple; beard yellow. Tall and large. Splendid strong grower, free bloomer, considered one of the finest American raised varieties. $\$ 5.00$.

69-Leonidas (pall.). S. clear mauve; F. rosy mauve. Large, fine form, tall and handsome. Fine for massing. $35 \mathrm{c}$.

70-Lewis Trowbridge (pall., Farr 1913). S. bright violet; 'F. blue-violet shaded rose. Very large flower with wide S. and F. 33 in. $75 \mathrm{c}$.

509-Lilacina (syn. Lila, 1841). White, bordered and veined pale blue. Pretty. 32 in. $25 \mathrm{c}$.

71 -Lohengrin (pall., G. \& K. 1910, A. M., R. H. S. 1916). Lilac rose; very large and beautiful. $50 \mathrm{c}$.

627-Lord Grey (sq., Lmn. 1840). Clouded rose fawn. $2 \mathrm{ft}$. $25 \mathrm{c}$.

65-Lord of June (Yeld 1916, A. M.). An exceedingly handsome Iris of huge proportions. $S$. of lavender blue; F. rich violet blue. Very bold and vigorous habit. One of the finest of Irises and much sought after. 40 in. $\$ 5.00$.

257-Loreley (var., G. \& K. 1909, H. C., R. H. S. 1916). S. light yellow; F. ultramarine blue, bordered cream. Handsome. $35 \mathrm{c}$.

230 -Louis Meyer (var.). S. golden; F. rich velvety purple, ret. white at claw. 21 in. $25 \mathrm{c}$.

426-Louis Van Houtte (neg., Lmn, 1840). S. pearly lavender; F. ret. darker. Pretty. $25 \mathrm{c}$.

629-Lucy (sq.). S. sulphur splashed lilac; F. full lilac. Pretty. 30 in. $25 \mathrm{c}$.

†72-M. Aymard (pall., Den. 1911). A darker form of Her Majesty. S. palest shade of Bishop's violet; F. a paler ground with a distinct veining of purple. $\$ 3.00$.

511 -Madam Chereau.-See Mme. Chereau. 630-Magnifica (sq. 1886). S. olive, shaded red; F. dark brown red, a beautiful variety. $75 \mathrm{c}$.

$\dagger 74$-Maiden's Blush (pall. Perry). A great improvement over Mrs. Alan Gray. Stout stems bearing numerous flowers, uniform shade of rosy-mauve. $\$ 2.50$.

611 -Malvina (Syn. Eleon, Lmn. 1858). S. old gold; flushed and spotted purple brown; F. dark maroon, ret. white. $2 \mathrm{ft}$. $25 \mathrm{c}$.

521 -Ma Mie (pl., Cay. 1906). White frilled with blue, a great improved Mme. Chereau, itself one of the most beautiful Irises. $3 \mathrm{ft}$. $50 \mathrm{c}$.

75-Mandraliscae (pall.). Rich lavender purple, tall, large, handsome, early. 40 in. $25 \mathrm{c}$.

233-Maori King (var., Ware 1890). S. golden yellow; $F$. velvety crimson, margined gold. Beautiful. 18 in. $35 \mathrm{c}$.

234-Marenco (var. 1897). S. yellow; F. rich crimson brown, ret. yellow. Very pretty. $20 \mathrm{c}$.

(See page 5.) 


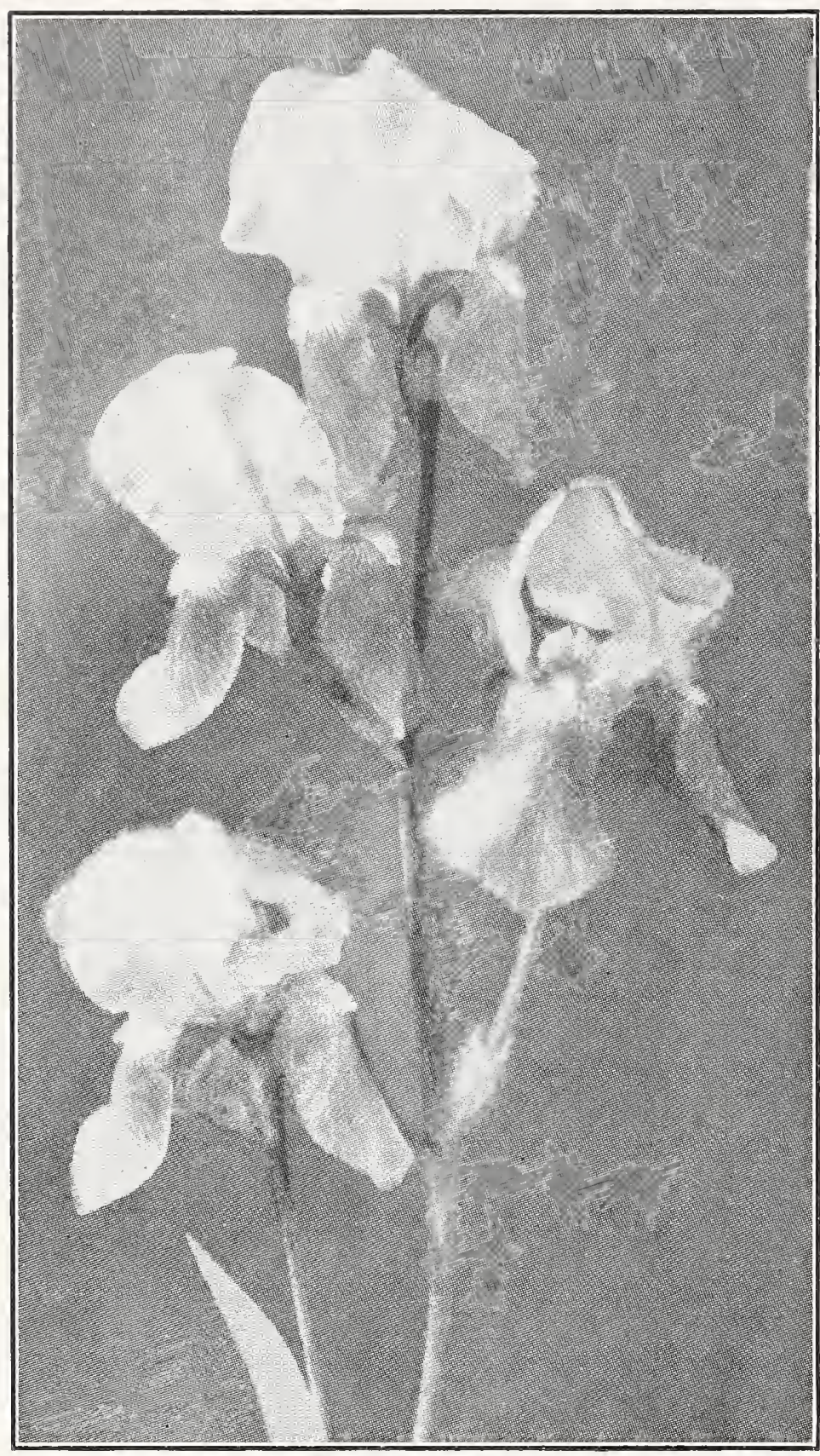

Lord of June

†1317-Margaret Moor (Bliss 1918). Somewhat similar to Mrs. Alan Gray, almost a self, but for the deeper color in the F.; the whole flower is of delightful reddish lilac color, very fascinating. 33 in. $\$ 5.00$.

427-Marian (neg.). S. lavender: F. lavender, ret. purple. Soft distinct color. $2 \mathrm{ft}$. $20 \mathrm{c}$.

510-Maritana (pl., Ware 1895). S. white; F. cream, with the rose-lilac lacing heavier on the edging and darker there than in the center. $35 \mathrm{c}$.

631 -Marmora (sq. 1854). S. sulphur and fawn; F. crimson purple margined lavender. 22 in. $25 \mathrm{c}$.

$\uparrow 1318$-Marsh Marigold (Bliss 1919). One of the most striking yellow varieties. A greatly improved Maori King, about 30 in. high. S. pale golden yellow; F. deep purple-brown with a bright yellow margin. $\$ 15.00$.

$\dagger$ Not for sale until after August 20th, 1922.
655-Mary Garden (sq., Farr 1913). S. pale yellow, flushed pale lavender; long, drooping $F$. creamy white, minutely dotted and veined maroon; stigmas clear yellow. 28 in. $50 \mathrm{c}$.

76-Mary Gray (pall., Farr 1913). S. clear lavender-blue; F. dark lobelia-blue. Handsome, large flowers. $3 \mathrm{ft}$. $\$ 1.00$.

313-Mary Minanelle (am. 1854). Pure white with a tinge of lavender. Pretty. 18 in. $25 \mathrm{c}$.

$\$ 84$-Mary Orth (pall., Farr 1920). S. light blue-violet; F. dark blue violet. Large flowers of fine form and color. $\$ 2.50$.

133-Mauvine (Named by Dean 1919). S. mauve; F. a few shades darker of same color. Tall, free flowering, handsome and distinct. $50 \mathrm{c}$.

718-Mephistopheles (syn. Sambucina Mep. Dutch 1889). S. clouded lavender; F. rich purple, flushed blue, sweet scented. $25 \mathrm{c}$.

$\dagger 1341$-Mercedes (Vilm.). S. purple lilac, shaded brown towards the claw. F. ivory white ground veined and dotted purple, the color deepening towards the edge. Style arms yellow with mauve edge. 30 in. $\$ 5.00$.

235-Mexicana (syn. Mexicaine, var., Sal. before 1859). S. very clear yellow; F. maroon, ret. white, handsome. 18 in. $20 \mathrm{c}$.

78-Midnight. A rich very deep purple, one of the finest in this color. $50 \mathrm{c}$.

$\dagger 258$ - Minnehaha (var., Farr 1913). S. creamy white, shaded yellow; F. creamy white, heavily ret. maroon; stigmas, clear yellow. Fragrant. Very large. $2 \mathrm{ft}$. $\$ 1.00$.

634-Miralba (sq., Lmn. 1848). S. rosy lavender: $F$. white tipped violet. $20 \mathrm{c}$.

$\uparrow 1343$-Miriam (Vilm.). Very distinct. S. palest lilac; $F$. a pale lilac ground richly veined with reddish purple. $2 \mathrm{ft}$. $\$ 3.50$.

428-Miss Brough (neg.). S. rich rose claret; F. a deeper hue. $20 \mathrm{c}$.

259-Miss Eardley (Perry 1910, A. M., R. H. S.). Handsome distinct form of variegata. S. golden yellow; F. rich madder red with yellow. $75 \mathrm{c}$.

260-Mithras (var., G. \& K. 1910, H. C., R. H. S. 1916). S. light yellow; F. brilliant wine red with narrow border of deep yellow. Beau. tiful. $35 \mathrm{c}$.

$\uparrow 1340$-Mlle. Schwartz (Den. 1916). A magnificent Iris considered by many the best of $M$. Denis' seedlings. One of the tallest Irises in cultivation with branching spikes bearing exceptionally large flowers of pallida form. Color palest mauve, many shades lighter than Dalmatica. $4 \mathrm{ft}$. $\$ 10.00$.

654-Mme. Blanche Pion (sq., Cay. 1906, H. C., R. H. S. 1916). S. pale bronze yellow, shot with lavender; F. rich purple. A handsome distinct Iris. $\$ 1.00$.

511 -Mme. Chereau (pl., Lmn. 1844). White, elegantly frilled with a wide border of pale blue. Handsome and very popular. 32 in. $20 \mathrm{c}$.

532-Mme. de Sevigne (pl., Den. 1916). A fine large plicata, with violet-purple markings. $\$ 3.00$.

(See page 5.) 
519-Mme. Guerville (pl. 1860). S. bright violet sanded and veined on white; $F$. bluishviolet striped on white. 31 in. $35 \mathrm{c}$.

73-Mme. Pacquette (pall., Lmn. 1848). Bright rosy claret, gorgeous, early, tall. $25 \mathrm{c}$.

513-Mme. Thibault (pl.). White, bordered violet. $25 \mathrm{c}$.

236-Monhassan (var.). Lively yellow S.; F. brown with a wide yellow border, handsome. $25 \mathrm{c}$.

430-Mons du Sible (neg.). S. lilac; F. deep crimson purple. Pretty. 30 in. $20 \mathrm{c}$.

450-Monsignor (neg., Vilm. 1907, cert., N. H. F. 1915; C., R. H. S. 1916). Distinct, beautiful rich coloring. S. pale unveined violet; $F$. a ground work of same shade but richly overlaid and veined (except for a broad margin), with deep purple. $50 \mathrm{c}$.

269-Mont d'Or (var., Per.). S. and F. rich old gold. Attractive. 32 in. $50 \mathrm{c}$.

$\$ 82$-Monte Baldo (pall., Per.). S. and F. uniform shades of rich blue with conspicuous yellow beard. Extremely pretty. \$1.50.

261 -Montezuma (var., Farr 1909). deep golden yellow minutely dotted brown; $F$. yellow and white veined purple and dotted brown. $\$ 1.50$.

314 -Morphee (syn. Morpheus, am., Lmn. 1840). S. white; F. white heavily tipped and traced violet-purple. 20 in. $20 \mathrm{c}$.

†1319-Morwell (Bliss 1917, A. M., R. H. S. 1916). A giant pale blue purple, both in $S$. and $F$. Larger, freeer flowering and a stronger grower than Caterina. 30 in. $\$ 7.50$.

83-Mount Penn (pall., Farr 1909). S. lavender rose: F. crimson lilac, deep orang beard. Tall and handsome and a great favorite. 30 in. $\$ 1.00$.

633-Mozart (sq., 1854). S. bronze fawn; F. purple fawn, netted white. A stately flower. 30 in. $35 c$.

315-Mr. Gladstone (am.). S. white, tinged violet; F. velvety purple. Handsome. 30 in. $50 \mathrm{c}$.

81-Mrs. Alan Gray (pall., Fos. 1909, H. C., R. H. S. 1916). A delightful lilac shade which gives one the impression of pink when comparing with other Irises. Often flowers again in August. Most beautiful. Fine for massing. 30 in. $50 \mathrm{c}$.

$\dagger 1320$-Mrs. Cowley (Bliss 1920). Early and free flowering. S. coppery pink; F. deep rich rosy-purple. Striking and beautiful on account of its quiet coloring. 27 in. \$4.00.

656-Mrs. Dugdale (sq.). S. rich old gold, of flushed bronze; F. rich claret, veined white. Attractive. $50 \mathrm{c}$.

317-Mrs. G. Darwin (am., Fos. 1897). White, upper parts of F. ret. gold and violet, golden beard. Very pretty. $2 \mathrm{ft} .35 \mathrm{c}$.

316 -Mrs. H. Darwin (am., Fos. 1893, $\mathrm{H}$. C., R. H. S. 1916). S. white; F. slightly ret. violet. $2 \mathrm{ft}$. $20 \mathrm{c}$.

56-Mrs. Kingscote (Syn. Hon. Mrs. Thos. Kingscote, Perry 1911). A fine Pallida. 5 . silvery rose; F. rose pink with conspicuous yellow crest. $\$ 1.50$.
238-Mrs. Neubronner (var., Ware about 1898, H. C., R. H. S. 1916). Very deep golden yellow, darker than Aurea. Very fine. $2 \mathrm{ft}$. $35 \mathrm{c}$.

512-Mrs. Reuthe (pl., Ware 1899). White, shaded and veined blue gray; F. white, frilled soft blue. Very large, handsome. $25 \mathrm{c}$.

$\dagger 1321$-Mrs. Tinley (Bliss 1920). An improved Cengialti pallida hybrid. Early producing large flowers of an intense self violet blue, with a characteristic golden blotch. A magnificent plant. $3 \mathrm{ft} . \quad \$ 10.00$.

239-Munico (syn. Munica, var.). S. bright gold; F. mahogany brown. $25 \mathrm{c}$.

710 -Munite (syn. Flavescens Munite, 1884). $S$ chamois yellow; F. primrose ret. lavender. $25 \mathrm{c}$.

636-Murat (sq.). S. fawn and coppery rose; F. crimson purple. 23 in. $20 \mathrm{c}$.

431 -National (neg., Lmn. 1840). S. clear blue; F. dark blue. Pretty. $2 \mathrm{ft} .25 \mathrm{c}$.

262-Navajo (var., Farr 1913). S. light bronze yellow shaded lavender; F. deep maroon heavily veined white and yellow; stigmas, yellow, deep orange beard. 20 in. $\$ 1.00$

432-Neglecta (neg. 1835). S. pale lavender; F. purple, ret. white. $20 \mathrm{c}$.

308-Nemours (syn. Duc de Nemours, am., Lmn. 1848). S. white; F. purple edged white. 26 in. $25 \mathrm{c}$.

85-Neptune (pall., Yeld 1916, A. M., R. H. S.). S. bright pale blue; F. rich dark purpleblue; the tall branching habit sets off nobly its large flowers and wide spreading falls. Splendid flower. $\$ 3.00$.

657 -Nibelungen (sq., G. \& K. 1910, A. M., R. H. S. 1916). S. fawn; F. violet purple or bronze, large, strong grower and free bloomer. $50 \mathrm{c}$.

$\nmid 87$-Nine Wells (pall., Fos. 1909). S. light blue; F. deep purple violet, showing a white ground at the throat. Smaller, darker and more velvety than Amas. Strong grower, late flowering. $4 \mathrm{ft}$. $\$ 1.00$.

325-Nokomis (am., Farr 1915). S. pale lavender white; F. deep dark violet blue bordered white. Tall grower, free flowering. $50 \mathrm{c}$.

658-Nuee d'Orage (sq., Ver. 1905, cert., N. H. F. 1905). Grayish slaty blue with bronze shading; F. purplish, not inappropriately called Storm Cloud. Vigorous, large. \$1.00.

86-Odoratissima (pall.). Uniform shade of rich lavender blue, sweetly scented. Very tall stout stems; flowers very large and very beautiful. Attracts great attention on account of its size, beauty and sweet scented qualities. $4 \mathrm{ft}$. $\$ 1.00$.

$\uparrow 1344-$ Olivia (Hort 1920). Tall and slender stems shaded a distinct blue-purple. Flowers almost self-colored of a pale shade of soft lavender. A most distinct color and difficult to describe. Late flowering. First class variety in every respect. $\$ 6.00$.

$\dagger 1345$-Opera (Vilm. 1916, Cert., N. H. F. 1914). A very distinct variety with fine flowers of good shape. S. dark purple bronze; F.

$\dagger$ Not for sale until after August 1st, 1922. (See page 5). 
similar coloring but much deeper and richer. 33 in. $\$ 3.00$.

$\uparrow 138$-Oporto (Yeld 1911). S. and F. rich purplish mauve with conspicuous orange beard. Large flowers of good substance. $50 \mathrm{c}$.

88 -Oriental (pall., Farr 1915). S. clear blue; F. rich royal blue, with a heavy bright orange beard, forming a striking contrast. 32 in. $75 \mathrm{c}$.

89-Oriflamme (pall., Vilm. 1904, cert., N. H. F. 1905; A. M., R. H. S. 1916). S. lavender of great size: F. deep velvety violet blue; broad, long, firm-textured. An immense handsome flower. $\$ 1.00$.

433-Osis (neg.). S. lilac; F. dark velvety purple. 20 in. $25 \mathrm{c}$.

240 -Ossian (var. 1868). S. straw yellow;

F. bluish violet. $25 \mathrm{c}$.

263-Ossian (var., Wallace 1912, A. M. at Int. Show 1912). S. pale yellow; F. claret red. Handsome. 30 in. $35 \mathrm{c}$.

434 -Othello (syn. Sappho, neg.). S. rich

blue; F. deep dark velvety purple. 30 in. $25 \mathrm{c}$.

73-Pacquita.-See Mme. Pacquette.

†139-Palaurea (Sturt. 1918, F. C. C., M. H. S.). Of shaded lobelia violet color with a warm glow of yellow through the center of the Hower. $3 \mathrm{ft}$. $\$ 1.00$.

90 -Pallida Dalmatica (pall., Cult. before 1600, A. M., R. H. S. 1916). S. lavender; F. clear deep lavender; Howers very large, extra fine. A grand variety for massing and for cut flowers. 42 in. $35 \mathrm{c}$.

91 -Pallida Speciosa.-See Speciosa.

$\dagger 1346$-Paragon (Wal. 1920). S. pale lavender-blue; F. a slightly deeper shade flushed rosy-purple, pale brown marking on the haft. Practically a self. Early strong grower and free flowering. 42 in. $\$ 4.00$.

92-Parc de Neuilly (pall., Verd. 1910). An excellent rich purple self approaching plum, not quite as dark as Kochii; very large blooms. Exceedingly beautiful and attractive. 24 in. $\$ 1.00$.

522-Parisiana (pl., Vilm. 1911). S. white, dotted and shaded light purple; $F$. white frilled and edged with lilac. Large and beautiful flower. $75 \mathrm{c}$.

93-Patience (pall., Fos. 1909). A quaint color scheme; S. grayish mauve; F. deep purple. Very floriferous and of interest on account of flowering later in June than other Irises. 3 ft. $75 \mathrm{c}$.

94-Pauline (pall., Farr 1913). S. and F. Unusually large, rich pansy violet, deep orange beard; fragrant. $3 \mathrm{ft}$. $50 \mathrm{c}$.

$\nmid 241$-Paxatawny (Farr 1918). S. pale parma-violet, slightly suffused sulphur-yellow, deepening at the base; F. darker, with brown and yellow reticulations. Very large flower. $3 \mathrm{ft}$. $75 \mathrm{c}$.

318-Penelope (am., Sal. before 1859). White, delicately veined reddish violet. Pretty. $25 \mathrm{c}$.

†95-Penge (pall.-ceng., Fos. 1913). S. light bluish violet; $F$. violet-purple, a neat rath-

$\dagger$ Not for sale until after. August 20th, 1922.

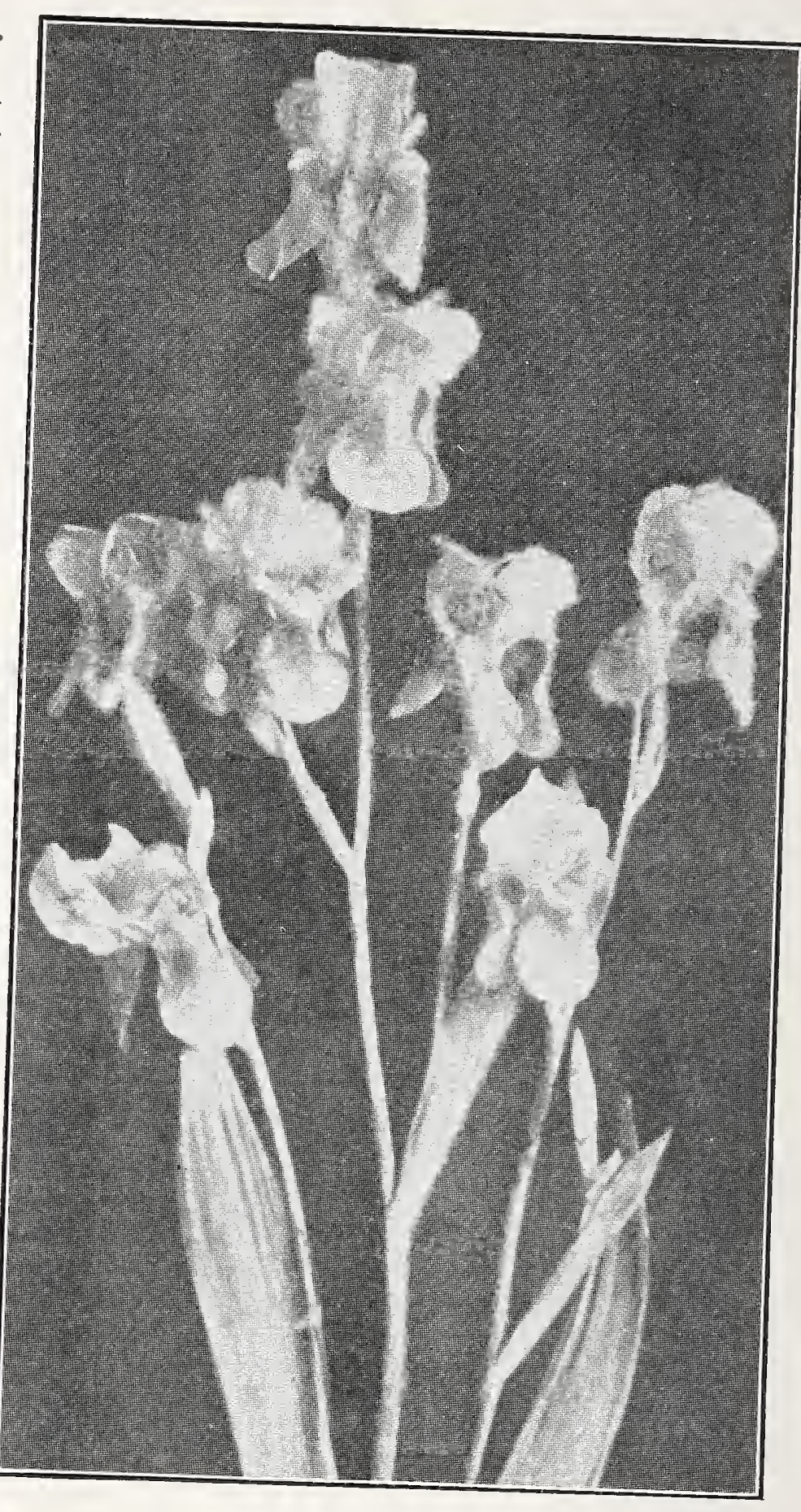

E. H. Jenkins

er than large flower and notable for its rich early profusion of flowers. 30 in. $75 \mathrm{c}$.

96-Perfecta (pall.). Soft rosy violet with orange beard. Pretty. $25 \mathrm{c}$.

435-Perfection (neg., Barr, H. C., R. H. S. 1916). S. light blue; F. dark violet, black orange beard. A handsome and popular Iris.
$35 \mathrm{c}$.

243-Pfauenauge (Peacock, var., G. \& K. 1906). S. all of gold; F. peacock blue with a gold border. Beautiful. $50 \mathrm{c}$.

244-Pharaon (var., Lmn. 1840). S. yellow; F. light mahogany. $20 \mathrm{c}$.

†1322-Phyllis Bliss (Bliss 1919). Very distinctive in shape and form, with flowers of a self pale rosy lavender. Flower spikes very strong and erect growing. One of Mr. Bliss's finest and most distinctive seedlings $\$ 25.00$.

(See page 5.) 
514 -Plicata Sappho (pl.). S. white, frilled lilac; F. pure white, ret. lilac at the base. Fine variety. $2 \mathrm{ft}$. $35 \mathrm{c}$.

97-Plumeri (pall. 1888). S. and F. deep coppery red; early and free flowering. Pretty. $20 \mathrm{c}$.

523-Pocahontas (pl., Farr 1915). S. and F. pure white, S. faintly bordered pale blue. Very large orchid type flower with elegantly frilled petals. $\$ 1.00$.

†98-Porcelain (Trojana, Fos. 1909). Late flowering seedling with a pleasing shade of china blue. Distinct in its much branched spike and profusion of flower. $30 \mathrm{in}$. $75 \mathrm{c}$.

99-Porcenna (Yeld 19...). S. coppery rose; F. crimson maroon; unusual in coloring and beautiful. $\$ 1.00$.

100-Powhatan (pall., Farr 1913). S. light bishop violet with deeper border; F. deep purple with crimson shade; large horizonta! spreading flower. 38 in. $50 \mathrm{c}$.

+270 -Prestige (var., Sturt. 1918, F. C. C.). S., style branches and edges of $F$. clear lemon yellow; haft and center of the F. are white with sharply defined veins of mars violet. . 26 in. $\$ 1.00$.

242-Prince d'Orage (var.). S. lilac white suffused at base with sunflower yellow; F. deep golden yellow washed and striped warm rich brown, beard richer yellow. $75 \mathrm{c}$.

245-Princess of Teck (var.). S. clear yel. low: F. a shade of purplish rose. Distinct. $35 \mathrm{c}$.

700 -Princess of Wales (Albicans). An absolutely pure white Iris. A grand flower. $35 \mathrm{c}$.

264-Princess Victoria Louise (var., G. \& K. 1910). S. soft primrose yellow; F. reddish purple with a distinct narrow primrose edge. $2 \mathrm{ft}$. 50c.

659-Prosper Laugier (sq., Ver. 1914, cert., N. H. F. 1905; A. M., R. H. S. 1916). On lines of Jacquesiana but with larger flowers and brighter in color. F. very broad of deepest velvety crimson; richly veined at the throat. Hand. some, very large flower. 32 in. $75 \mathrm{c}$.

†1347-Prospero (Yeld 1920, A. M. Chelsea, 1920). An exceedingly vigorous, tall growing variety, the stems bearing enormous flowers of fine shape. S. pale lavender flushed with yellow at base; $F$. deep red-purple with lighter shading at margin. Heavily marked with brown at the haft, deep orange beard. A particularly handsome plant. $4 \mathrm{ft}$. $\$ 5.00$.

101 -Quaker Lady (pall.-sq., Farr 1909). S. smoky lavender with yellow shading; $F$. ageratum-blue and old gold, stigmas yellow. Yellow beard. 38 in. $50 \mathrm{c}$.

638 -Queen Alexandra (sq., Barr 1910, H. C., R. H. S. 1916). S. fawn, shot with lilac; F. lilac ret. at base bronze, beard yellow. Very beautiful. 30 in. $50 \mathrm{c}$.

$\uparrow 140$ Queen Caterina (pall., Sturt. 1918, F. C. C., M. H. S. 1916). Pale lavender violet self with a white haft veined with bronze and a rich orange beard. 3 to $4 \mathrm{ft}$. $\$ 4.00$.

† Not for sale until after August 20th, 1922.
102-Queen of May (Sal. before 1859). A lovely rose lilac, almost pink. Beautiful. 32 in. $20 \mathrm{c}$.

660-Red Cloud (sq., Farr 1913). S. rosy lavender-bronze; $F$. velvety maroon-crimson, ret. yellow. Stigmas old gold. One of the deepest, richest and most beautiful in color. Very near red in general coloring. $2 \mathrm{ft} .75 \mathrm{c}$.

†1348-Regan (Hort 1920). Pallida x Trojana seedling, a very fine distinct dark purple, early flowering bicolor with exceptionally long falls, heavily ret. brown on a white ground. $\$ 5.00$.

246-Regina (var. 1876). S. yellow; F. white, conspicuously ret. lilac and edge primrose-yellow. 20 in. $50 \mathrm{c}$.

103-Rembrandt (pall. 1902). S. and F. soft lilac blue. $25 \mathrm{c}$.

320-Recticulata Alba (am. 1830). S. white; F. violet purple, edged and ret-white. $25 \mathrm{c}$.

327-Rhein Nixe (am., G. \& K. 1910, A. M., R. H. S. 1916). S. white, very large; F. rich violet purple with a narrow distinct white edge. Handsome. 50c.

330-Richard II (am., Dykes 1914, A. M., R. H. S.). Neat tufts of light green foliage, stout stems, floriferous. S. pure white; F. deep violet conspicuously margined white. Strong grower and a most fascinating variety. \$3.50.

247-Rigolette (var.). S. yellow: F. bright madder brown, ret. white. 16 in. $25 \mathrm{c}$.

105-Ringdove (pall., Fos. 1913). A very free flowering and beautiful seedling, with boldly erect stems sometimes exceeding $4 \mathrm{ft}$. in height and often as many as seventeen flowers on a single spike. The large $S$. are pale violet; F. a shade deeper, but the variety is most distinct in having a band of still deeper color at the throat. $\$ 2.00$.

$\dagger 1323$-Rodney (Bliss 1919). Large flowers of fine form. In color a dark self violet blue. Very blue tone. Strong grower and very free flowering. Splendid branching habit. 39 in. $\$ 5.00$.

†1326-Roseway (Bliss 1919). Deep redpink Pallida. Very early. Strong branching spikes. Brightest of the so-called red pallidas so far raised. Almost a self; with a very broad orange beard. $\$ 15.00$.

107-Rose Unique (pall., Farr 1910). S. and $F$. bright violet rose, very near to a pink Iris. Large flowering and a handsome variety. $75 \mathrm{c}$.

109-Rubella (pall.). S. rose lilac; F. crimson purple. Pretty. $3 \mathrm{ft} .20 \mathrm{c}$.

108-Rubberissima (pall. 1887). S. soft rose; $F$. velvety claret red. 30 in. $25 \mathrm{c}$.

640-Salar Jung. (sq. 1876). S. gold bronze, flaked maroon; F. tipped and ret. maroon, black on a white ground. 27 in. $25 \mathrm{c}$.

715-Sambucina (Cult. before 1823). Fragrant with odor of elder from which it derives its name. S. coppery rose; $F$. rose purple, with an orange crest. 27 in. $20 \mathrm{c}$.

$\dagger 110$-Sarpedon (pall., Yeld 1914). S. light violet blue; $F$. slightly darker. Large, with broad oblong falls. $\$ 1.00$.

(See page 5.) 


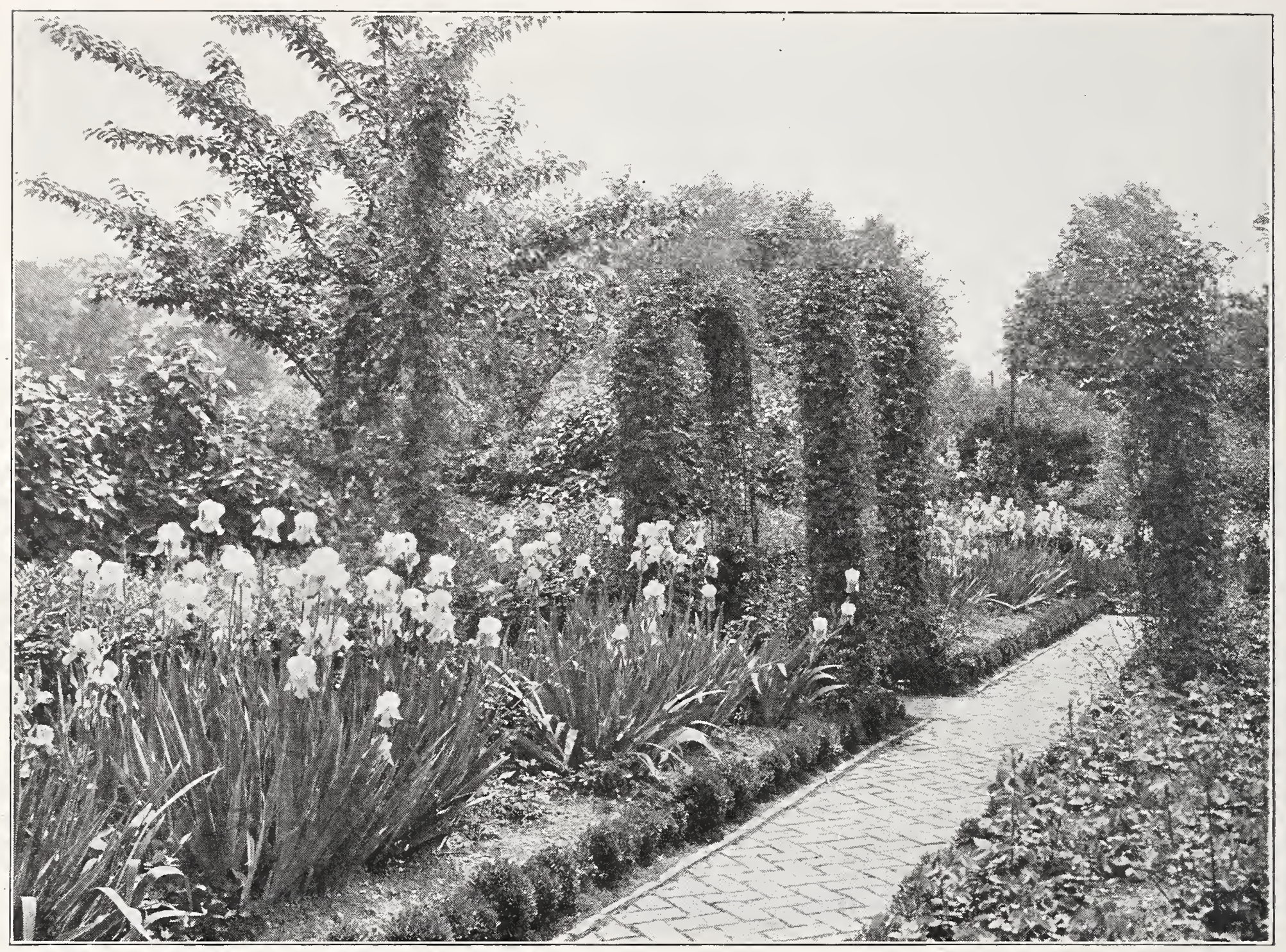

A Beautiful Iris Garden

†111-Seminole (Farr 1920). S. soft violet rose; $F$. rich velvety crimson, brilliant orange beard. Honorable mention by A. I. S. June 1920. \$2.50.

642-Shakespeare (sq.). S. bronze yellow; F. maroon ret. yellow. 26 in. $20 \mathrm{c}$.

†112-Shalimar (Wal. 1916). A Trojana seedling of fine size and rich violet-purple color, most remarkable for its branching habit which carries the numerous flowers in a broad spreading panicle. $3 \mathrm{ft}$. $\$ 2.50$.

$\uparrow 141$-Sherbert (Sturt. 1918). S. ecru drab deepening through cinnamon to purplish vinaceous; F. dahlia purple shading lighter at the edges. A very effective variety in height, shape and tone. 42 in. $\$ 3.00$.

267-Sherwin Wright (var., Koh. 1915). S. and F. golden yellow; vigorous grower, free flowering. This with Aurea, Mrs. Neubronner and Virginia Moore, are the four different selfcolored yellows. 24 in. $50 \mathrm{c}$.

$\$ 651$-Shrewsbury (sq., Farr 1916). S. rosy bronze; F. violet purple with lighter shading, the conspicuous heavy orange beard forming a brilliant contrast with the other colors. A striking variety. $75 \mathrm{c}$.

$\dagger$ Not for sale until after August 20th, 1922.
641 -Sir Walter Scott (sq.). S. bronze yellow: F. rich crimson brown. 26 in. 20 c.

115 -Sirdir (pall., Perry). Remarkably free, stcut branching stems, bearing many enormous flowers. S. bright blue faintly edged silver; F. crimson purple shading to dark mauve. $\$ 3.00$.

†117-Somercoates (Perry 1919). One of the freest flowering lrises introduced, stout stems bearing large well formed flowers. S. soft lavender-blue; F. crimson purple with brilliant orange crest. $\$ 3.00$.

436-Souvenir (neg.). Soft blue; very attractive. $25 \mathrm{c}$.

†1350-Souv. de Mme Gaudichau (Mil. 1914). Millet's best variety. A tall, early and very distinct variety; a deep purple bicolor of an unusual velvety appearance, the fine shape and finish of the flower giving great distinction to the plant. 42 in. $\$ 10.00$.

515-Sparte (probably Sal. 1868). S. pearly lavender, shaded rose; F. straw colored and veined lavender. $25 \mathrm{c}$.

91 -Speciosa (syn. Pall. Speciosa). S. dark lavender shaded light; F. shaded light purple; tall, large and handsome. 42 in. $35 \mathrm{c}$.

(See page 5.) 
$\dagger 118$-Stamboul (pall., Wal. 1916, H. C., R. H. S. 1916). S. light blue; F. rich violet blue, vigorous, free flowering. Somewhat like Caterina but quite distinct in its darker coloring and broader falls. $3 \mathrm{ft}$. $\$ 2.00$.

119-Standard Bearer (pall., Ware 1904). S. and $F$. rosy mauve. 38 in. $25 \mathrm{c}$.

$\nmid 271$-Stanley H. White (var., Sturt. 1919, F. C. C., M. H. S.). Empire yellow, F. lightly and thinly veined with aster purple; a charming flower; stalks well and distinctively branched. $3 \mathrm{ft}$. $\$ 5.00$.

120-Sultane (pall., Lmn. 1840). S. pale pink heliotrope; $F$. darker with inner petals matching the $S$. $25 \mathrm{c}$.

$\lceil 1351$-Sunshine (Yeld 1919, A. M., R. H. S.). A brilliant self-colored yellow variety. Very effective when massed. 30 in. $\$ 5.00$.

643-Swatara (sq., Farr 1918). S. lobeliablue suffused bronzy-yellow at base. F. bright violet with conspicuous orange beard. Coloring rich and warm. Large flower, fine form. 3 ft. $75 \mathrm{c}$.

516-Swerti (pl. 1612). White frilled blue, petaloid stigmas lilac. $35 \mathrm{c}$.

$\dagger 1325$-Syphax (Bliss 1917, C., R. H. S. 1916). S. pale violet; F. deep crimson purple, boldly ret. at the haft; free flowering. F. hang almost vertical giving the flower a unique shape. 30 in. $\$ 5.00$.

121 -Tamerland (pall., Vilm. 1904). Deep purple-violet falls, with paler S. Is close to Trojana but rather earlier. A magnificent tall, bold free flowering lris. 30 in. \$1.00.

†1327-Tartarin (Bliss 1919). An extraordinary variety, producing enormous flowers, larger than any other, of two distinct shades of pale lilac lavender blue. Beautiful, huge flowers on stout stems. $3 \mathrm{ft}$. $\$ 5.00$.

649-Tecumseh (sq., Farr 1910). S. clouded buff: F. smoky violet, bordered yellow, crimson spathe valves. 30 in. $35 \mathrm{c}$.

437 -Teresita (neg.). S. lavender, flushed lilac; F. crimson purple, 28 in. 20 c.

661 -The President (sq.). S. light copper, flaked with purple-bronze; F. very dark, velvety maroon with brown and white at the base. Very striking. $2 \mathrm{ft}$. $\$ 1.00$.

451 -Thora (neg., G. \& K. 1910). S. white tinging as they age with blue. F. deep purple, solid at the base but at the throat showing a white ground finely veined with dark purple. Late flowering and very floriferous. $\$ 1.00$.

321 -Thorbecke (am., before 1912).

white; F. rich clear violet blue, ret. white at the base. Pretty. $25 \mathrm{c}$.

123-Tineae (pall.). Deep blue shaded lilac. Large flower. 40 in. $25 \mathrm{c}$.

251 -Tom Cook (var.). S. dark yellow; F. bronze yellow veined crimson. Pretty. $25 \mathrm{c}$.

†1328-Tom Tit (Bliss 1919). A unique plant. Generally admired. Flowers are small, 3-4 on a stem of a deep self violet-blue. $F$. almost horizontal. Most decorative plant and will be much sought after. $2 \mathrm{ft}$. $\$ 4.00$.

124-Troutlieb (pall., G. \& K. 1899). A uniform soft rose. Very fine. $50 \mathrm{c}$.

$\dagger$ Not for sale until after August 20th, 1922.

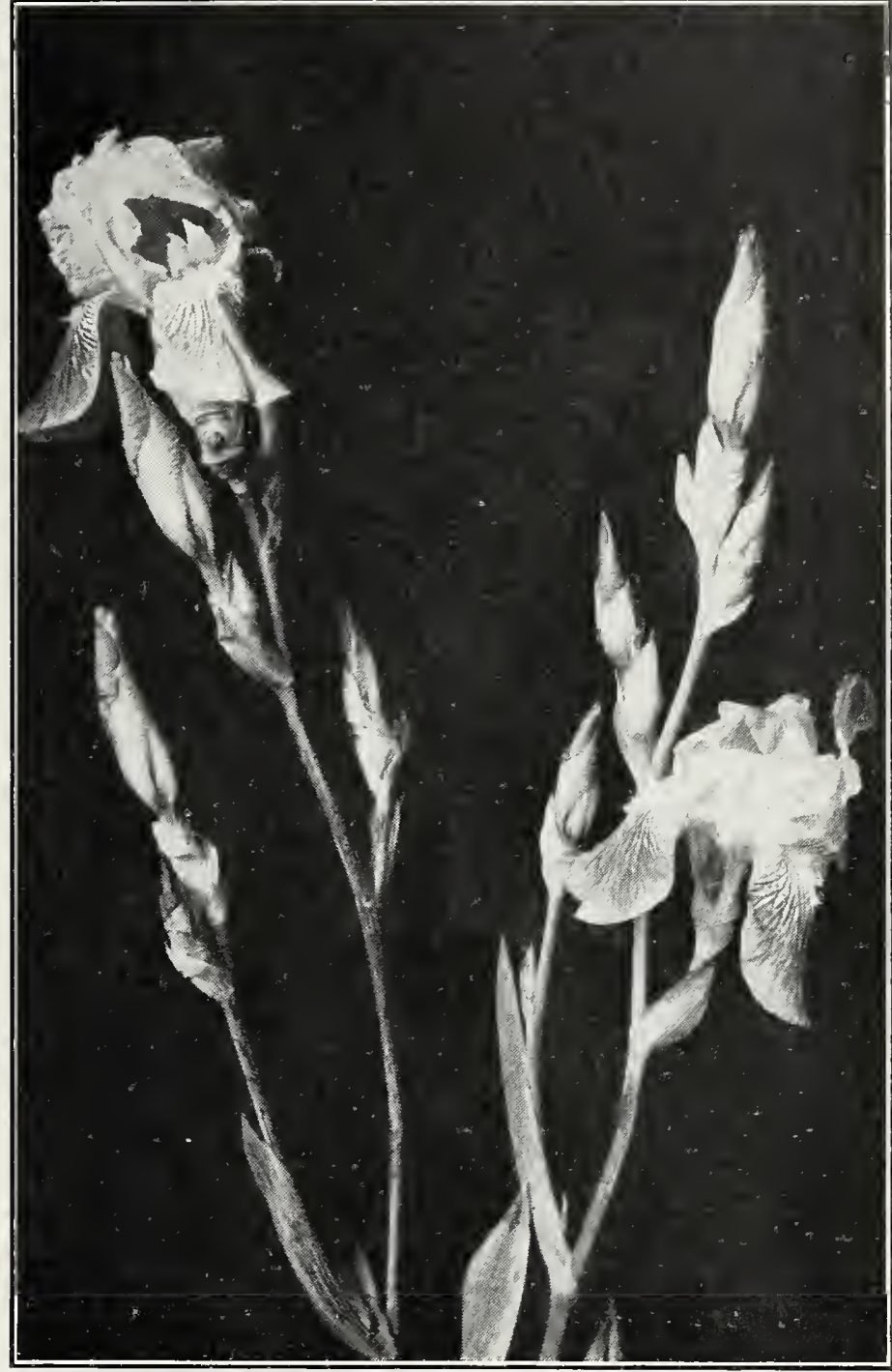

(130) Windham

Successive Bud Development Causes Continued Blooms

†1329-Tristram (am., Eliss 1919). S. of clearest white; F. deep rich purple, richly ret. at haft. Most distinctive and beautiful. 27 in. $\$ 5.00$.

719-Trojana (Asiatica of some gardens. Kerner, A. M., R. H. S.). A magnificent plant $3.4 \mathrm{ft}$. high, with branched spikes of very large flowers. S. light violet-blue; F. deep purple violet. $35 \mathrm{c}$.

722-Trojana Superba. S. soft pale blue; F. rich clear violet-purple. Large flowers, extra fine. 30 in. $50 \mathrm{c}$.

†1352-Troost (Den. 1908). S. deep rosy purple; F. paler, veined violet, which changes to brown in the upper part, giving a distinctive appearance. A greatly improved M. Aymard, deeper in color and unique on account of the brown shading of the haft. $2 \mathrm{ft}$. $\$ 5.00$.

$\dagger 1353$-Tuscany (Wal. 1920). An attractive Trojana seedling, strong grower with handsome showy flowers. S. bright blue; F. exceptionally long, of a deep purple-red, similar to Shaliniar. $3 \mathrm{ft}$. $\$ 6.00$.

322-Unique (am., Lmn. 1840). S. white; F. violet mingled white. $20 \mathrm{c}$.

(See page 5.) 
$\uparrow 142$-Ute Chief (pall., Farr 1920). S. light blue-violet; F. rich royal purple, heavily ret. Extra large. $3 \mathrm{ft}$. $\$ 2.50$.

266-Venus (var., Sal.). S. lemon yellow; F. white ground, deeply veined purple. $25 \mathrm{c}$.

644-Venusta (sq., Sal. 1868). S. sulphur shot with bronze; F. maroon. Pretty. 26 in. $25 \mathrm{c}$.

717 -Vesuve (syn. Sambucina La Vesuve, Lmn. 1858). S. lavender, flushed bronze; $F$. violet. 26 in. $25 \mathrm{c}$.

323 -Victorine (am., Lmn. 1840). S. white, mottled blue; F. violet blue, mottled blue. Beautiful. 27 in. $25 \mathrm{c}$.

125-Viola (pall.-ceng., Fos. 1913). Flowers of a uniform light bluish violet on erect three foot stems. Very charming and handsome, unusually floriferous. $75 \mathrm{c}$.

126-Violacea Grandiflora (pall. 1860). S. rich blue; F. violet blue. Handsome. $25 \mathrm{c}$.

$\uparrow 252$-Virginia Moore (var., Shull 1921, H. M., A. I. S. 1920). The tallest yellow self to date standing 33 in. and giving a fine mass effect. The color is exactly the same shade of Hemerocallis flower. Slightly veined. Taller than Aurea, Mrs. Neubronner and Sherwin Wright. $\$ 3.00$.
445-Virginie (neg., Lmn. 1858). 12-91765-Rainbow Gardens-LEB white; F. rich purple lilac. Strong grower, fine for borders and massing. Pretty. 25c.

127-Walneri (pall.). S. lavender; F. purple lilac. Good foliage. 30 in. $25 \mathrm{c}$.

645-Walneriana (sq., Lmn. 1840). S. lavender, flushed bronze; F. pale violet. 30 in. $25 \mathrm{c}$.

128-White Knight (Saunders 1915). A beautiful absolutely snow white Iris, without markings of any kind. Delicately sweet scented. $\$ 1.00$.

130-Windham (pall., Farr 1909). S. very soft lavender pink; $F$. heavily veined with a darker shade. Very large flower. Very handsome. $75 \mathrm{c}$.

328-Wyomissing (am., Farr 1909). S. creamy white, suffused delicate soft rose; $F$. deep rose at the base, shading to a flesh colored border. A very beautiful lris with exquisite some. $75 \mathrm{c}$. (See page 20.)

\section{BEARDLESS IRISES (Apogon)}

These lrises are hardy and quite distinct from the Bearded lrises. They are tall and beautiful and a number of them may be treated as semi-aquatics.

No lris, no matter how much it loves moisture, will thrive well where water stands in winter, except our native water flag (Versicolor) and the European yellow flag (Pseudo-Acorus) which may be grown partially in water, and are unexcelled for ponds and boggy places. Plant if possible in early autumn or spring.

\section{BEARDLESS IRISES-Section 1 Siberian Irises}

\section{June and Early July Flowering}

The most delicate and elegant of all the smallflowered lris. Narrow, grassy foliage, with tall stems and flowers of various shades of blue, with white markings; very free-flowering, and one of the best for cutting.

Named varieties, unless noted, 20 cts. each, $\$ 2.00$ per doz., $\$ 12.50$ per 100

1000-Siberica Acuta. A distinct dwarf form; blue, reticulated white. $2 \mathrm{ft}$.

1001 -Siberica Alba Grandiflora. Flowers very large, pure white. $25 \mathrm{c}$

1002 -Baxteri. S. blue; F. white, slightly veined blue. $4 \mathrm{ft}$. $25 \mathrm{c}$.

1003 -Corean Species. Rich shades of violet purple, very handsome. $2 \mathrm{ft} .35 \mathrm{c}$.

1004 -Distinction. S. violet; F. white, freely veined and tipped blue. $3 \frac{1}{2} \mathrm{ft} .25 \mathrm{c}$ each, $\$ 2.50$ per doz.

† Not for sale until after August 20th, 1922.
1005-Flore Pleno. Deep blue, semi-double Howers. $21 / 2 \mathrm{ft}$.

1006 -George Wallace. Azure-blue; F. marked white. Extra fine. $3 \mathrm{ft} .35 \mathrm{c}$. $\$ 3.50$ per doz.

1007 -Grandis. Violet, reticulated white. 5 ft. $35 \mathrm{c}$.

1009-Lactea. Milky white: a beautiful variety. $3 \mathrm{ft} .35 \mathrm{c}$.

1010 -Orientalis (syn. Sanguinea). Intensely brilliant blue flowers, the bud being enclosed in conspicuous crimson spathe valves. $3 \mathrm{ft}$.

1011 -Orientalis, Blue King. A fine variety bearing handsome clear blue flowers. Found by Mr. Peter Barr in Japan. 25c each. $\$ 2.50$ per doz. $\$ 15$ per 100 .

1012 -Orientalis, Snow Queen. Large, ivory. white flowers. Found in Japan by Mr. Barr. $25 \mathrm{c}$ each. $\$ 2.50$ per doz.

1013-Orientalis Superba. Large, violetblue; handsome foliage, reaching almost to the flowers. 34.)

(See prices on special collections on page (See page 5.) 


\section{BEARDLESS IRISES-Section 2}

\section{Late June and July Flowering}

The Irises in this group, besides being handsome subjects for the flower and shrubbery border, may be planted by the waterside, but with their crowns above the water-level. The varieties of Orientalis, Aurea, and Monspur are grand and stately plants, growing from 4 to 5 feet in height, with beautiful erect, dark green foliage, which retains its beauty until well into winter. Grown together in masses the effect is most striking and beautiful.

900-Aurea. A beautiful species from the Himalayas, with handsome large flowers of the deepest golden yellow. $4 \mathrm{ft}$. June and July. $35 \mathrm{c}$ each. $\$ 3.50$ per doz.

903-Monspur. Handsome new Hybrids, raised by Prof. Foster. They are all strong growers, with flowers of various shades of blue, producing when massed, a glorious shimmering effect of violet-blue. $4 \mathrm{ft} .35 \mathrm{c}$ each.

904-Orientalis Gigantea (syn. Ochroleuca). The Gold-banded Iris. A noble Iris, growing some 5 feet in height, with handsome strong foliage, producing large flowers of ivory whiteness, with an orange-yellow blotch at the base of the falls. June and July. 50c (See illustration).

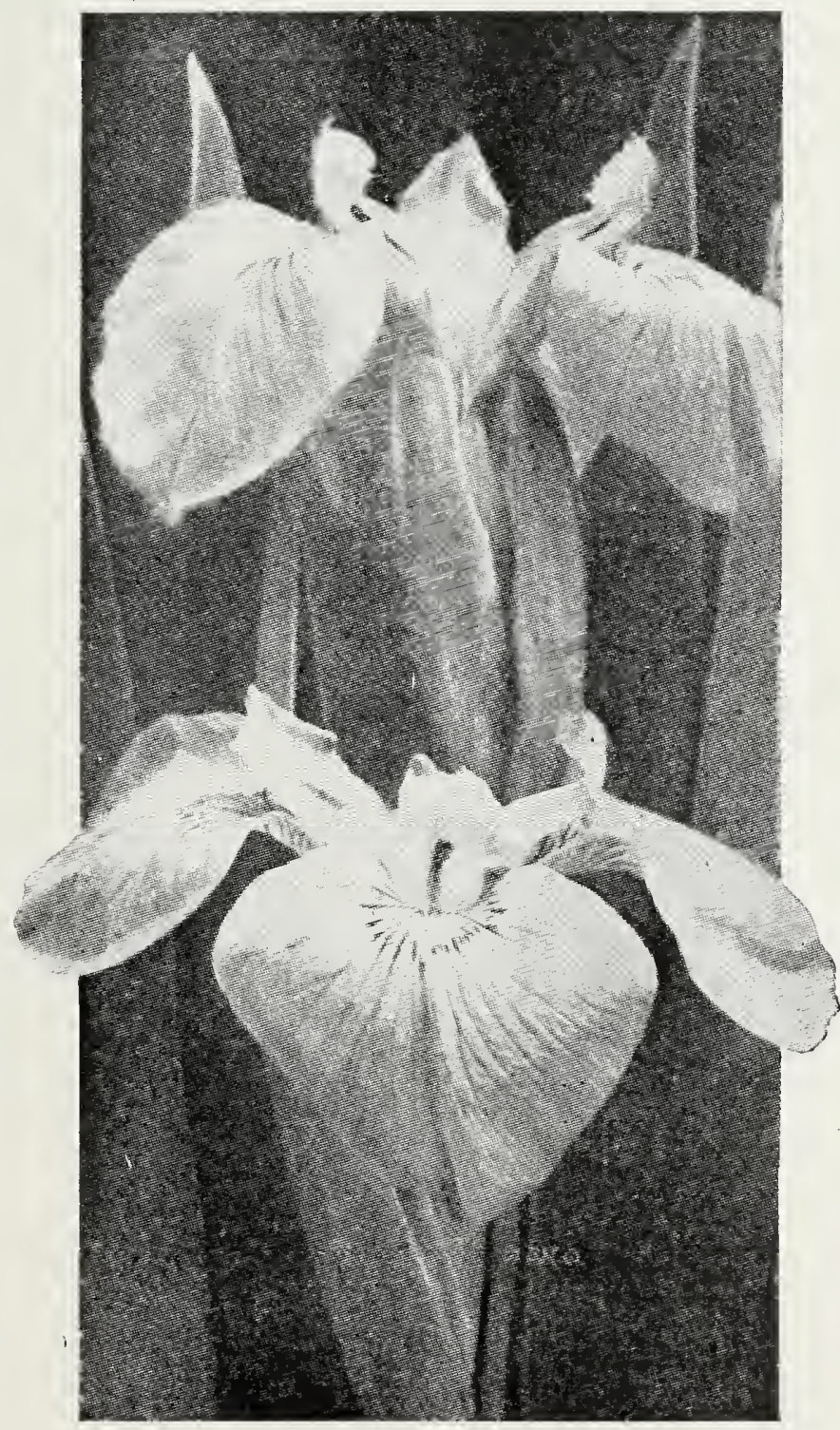

Pseudo-Acorus

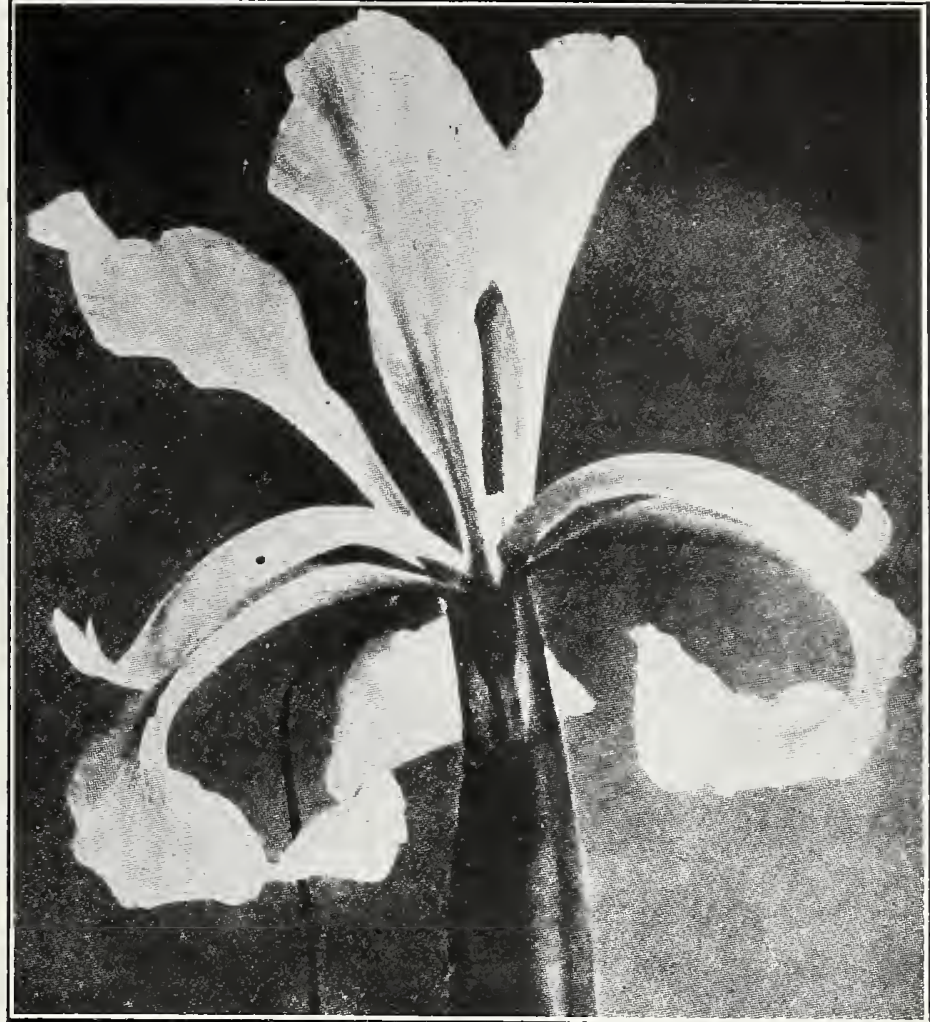

(904) Orientalis Gigantea

905-Orientalis Sulphurea. An improved form of Orientalis Gigantea, with pale sulphur flowers. $50 \mathrm{c}$.

906-Spuria. Bright lilac-blue. Fine for bor der as foliage remains green until late fall. 3 ft. June and July. $25 \mathrm{c}$.

907 - Spuria Celestial. Fine soft blue, with a yellow blotch; long flower stems, each producing five to six flowers. Fine for border as foliage remains green until late fall. $4 \mathrm{ft} .35 \mathrm{c}$.

908-Spuria, Mrs. A. W. Tait (syn. Longipetala Superba). Flowers soft porcelain-blue, with very long pale blue falls, having a golden blotch at the base; fine foliage, free bloomer, and very hardy. A lovely species, fine for massing. Foliage remains green until late fall. $3 \mathrm{ft}$. $35 \mathrm{c}$ each. $\$ 3.50$ per doz.

909-Spuria Notha. Standards rich violet; falls blue, spotted yellow; handsome; very strong grower. $3 \mathrm{ft}$. $35 \mathrm{c}$.

\section{BEARDLESS IRISES-Section 3}

\section{June and July Flowering}

Irises suitable for planting by the waterside, and in very damp or wet places. These will also do well in any good, loamy soil that is kept well cultivated and mellow.

975-Pseudo-acorus (The Common Yellow Water Flag). Bright yellow; suitable for marshes and water courses. These and Versicolor varieties are the only Irises that may be safely planted where water habitually stands. $3 \mathrm{ft}$. May and June. 25c. $\$ 2.00$ per doz.

979-Versicolor. A native species, common to our streams and marshes, flowering in June and July, remaining in bloom a long time; very showy violet-blue flowers. 25c. $\$ 2.00$ per doz. 


\section{JAPANESE IRIS (Iris Kaempferi) (Apogon)}

\section{Late June and July Flowering}

The magnificence of Japanese Irises is such that no written description gives them justice. Some of the flowers measure from 10 to 12 inches. The prevailing colors are white, rose-purple, crimson, rose, lilac, lavender, silvery gray, purple, violet and blue; each flower usually representing several shades. We have imported most of our Japanese Irises direct from Japan and give the true Japanese names. They flower from late June to August 5 th in this latitude.

Culture. These Irises are really semi-aquatic, and are seen in their full glory when grown at the water's edge. The Japanese grow them in their rice-fields, which are flooded during the summer but drained off in winter by means of ditches into the nearest creek, pond or stream. In Japan during winter while the plants are at vartial rest, they receive three to five waterings with liquid cow manure (not horse manure which is unsuitable). As soon as the plants start into growth in the spring they receive no more manure.

In this country they can be planted either as a water garden plant or in a dry location. They can be planted at the margin of streams or ponds. In dry soils they can be grown to perfection if the ground is kept hoed. Although they can be planted in the fall, spring planting is preferable. Always cover Japanese Irises with a good covering of straw or hay during the winter as they then require protection.

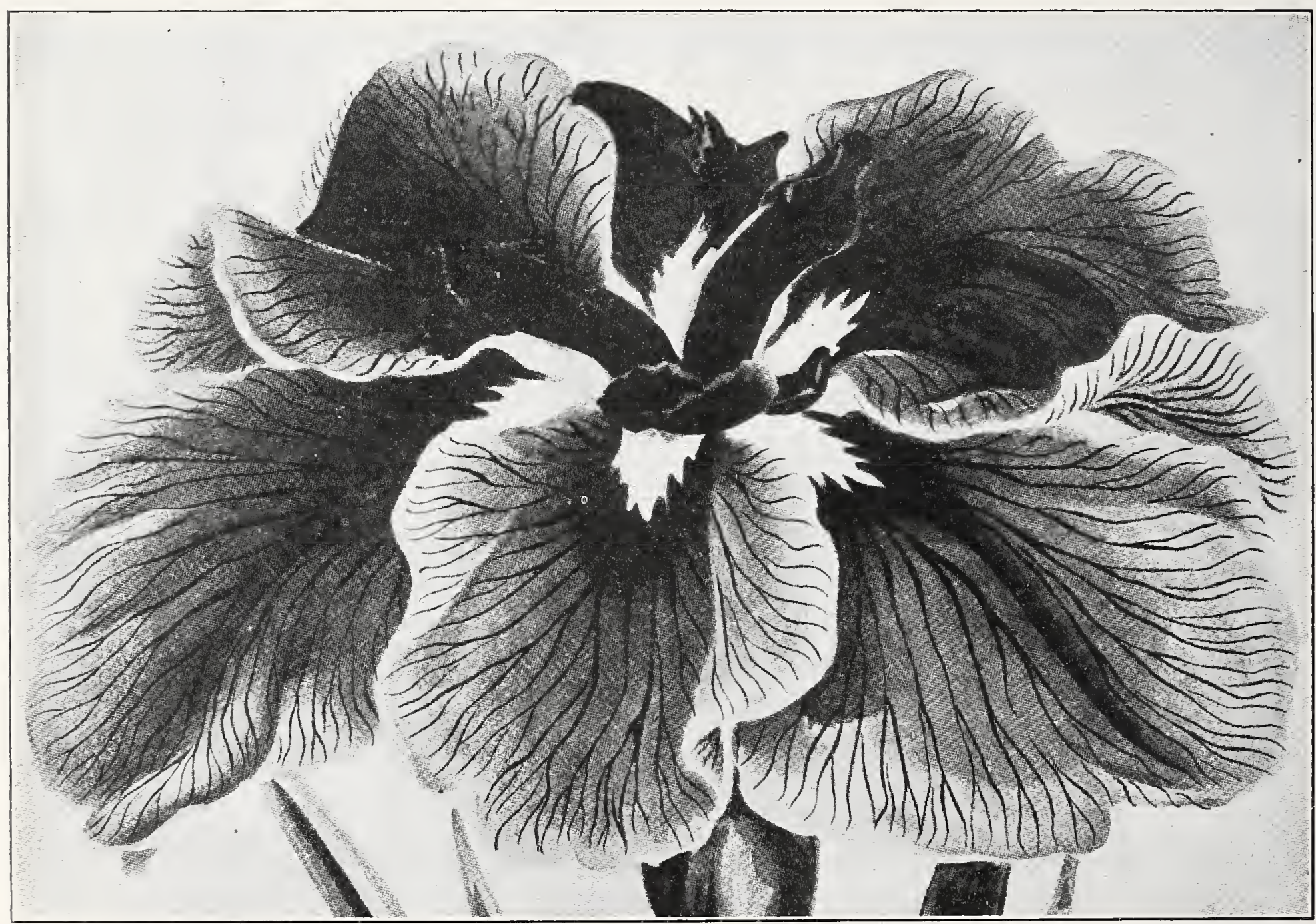

A Six-Petal Japanese Iris

(See front cover for three-petal Japanese Iris.)

1100 -Kumoisho. Vinous purple margined gray, yellow blotches surrounded with velvety crimson halo radiating into the petals in feathers and pencilings, petaloid stigmas dark violet, 6 petals. Handsome. (See illustration). $75 \mathrm{c}$.
1101 -Gekka-no-nami (Waves under moonlight). Dense pure white, yellow blotches, petaloid stigmas creamy, 6 petals. Handsome huge flower. $35 \mathrm{c}$. 


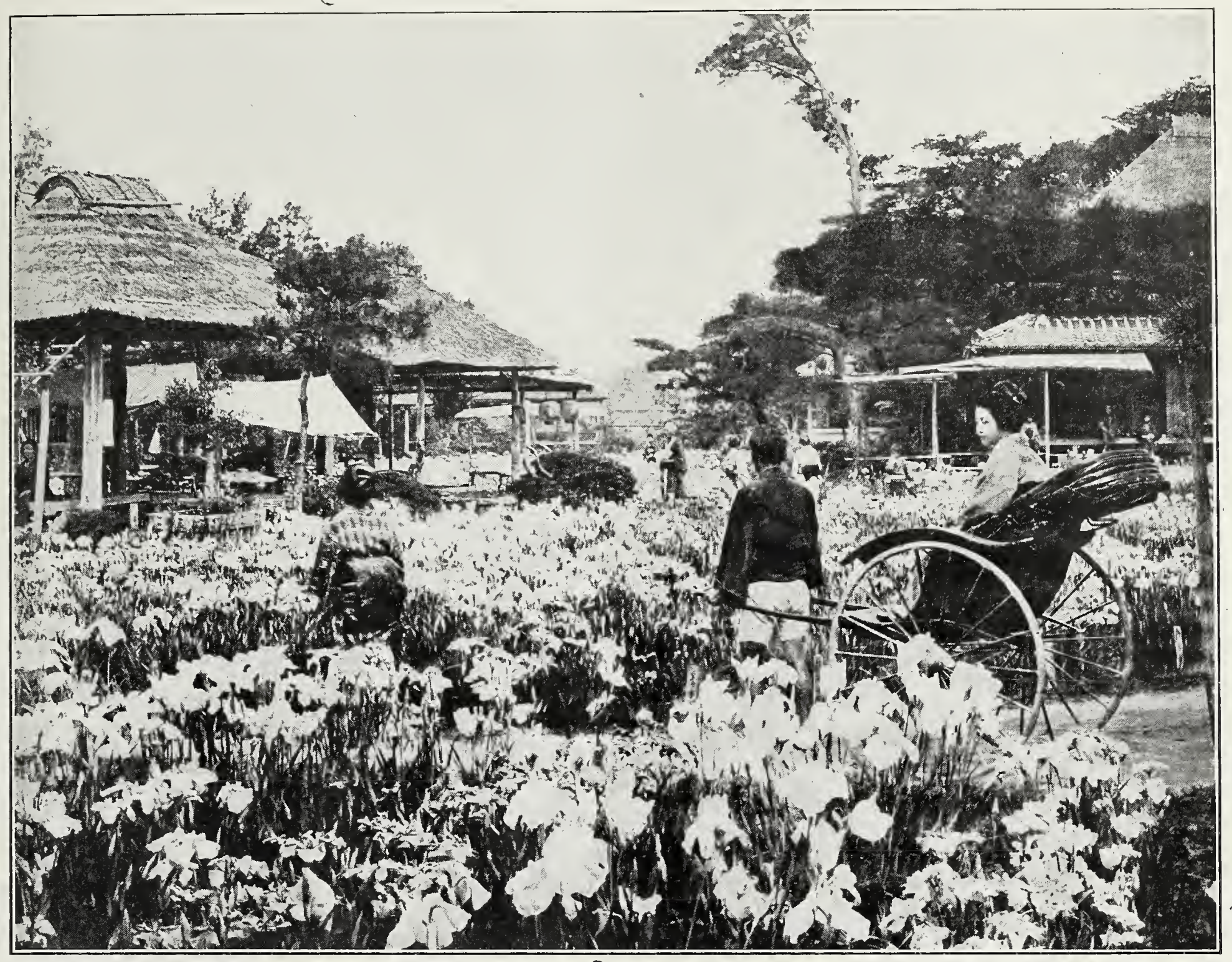

Japanese Irises in Japan

1103-Oyodo. Immense violet-blue petals, and very large standards, petaloid stigmas dark violet, 3 petals. Handsome huge flower. $35 \mathrm{c}$. 1104-Shippo (Cloisonne). Rich tyrianblue, edged purple and feathered white, yellow blotches, petaloid stigmas lavender-blue and white, 6 petals. $35 \mathrm{c}$.

$1105-$ Momiji-no-taki (Maple waterfall). Crimson-purple suffused and feathered white, petaloid stigmas white and purple, 6 petals. $35 \mathrm{c}$.

1106-O-torige. Light purple with blue halo surrounding the orange blotches radiating inte feathers all over the flower, claret colored standards tipped white, petaloid stigmas purpleblue tipped white, 3 petals. A magnificent huge flower. (See illustration on front cover.) $75 \mathrm{c}$.

1107-Manadzuru (Crane). White yellow biotches, radiating out into sky-blue feathers, petaloid stigmas violet tipped and speckled white. This variety will at times give a creamy white flower, 6 petals. Beautiful. $50 \mathrm{c}$.

1108 - Tsuru-no-kegoromo (Crane's feather). Large pure white flowers, yellow blotches, standard white, petaloid stigmas creamy, 3 petals. Huge handsome flower. $50 \mathrm{c}$.

1111 -Yezo-nishiki (Yezo-brocade). Deep rich crimson mottled and blotched white, 3 standards same color as petal, petaloid stigmas lavender-blue, 6 petals. $35 \mathrm{c}$.

1112 -Shiga-no-ura-nami. Red-lavender with white halo surrounding the yellow blotches and radiating out into the feathers, petaloid stigmas white tipped lavender, large flower, 6 petals. $35 \mathrm{c}$.

1114 -Kakujakuro. Blue and purple, heavily feathered white, yellow blotches, standards blue edged white, petaloid stigmas white tipped blue, very large flower, 3 petals. Handsome. $50 \mathrm{c}$.

1115-Shishi-ikari. Rich broad purple petals, orange blotches, 3 large standards same color, petaloid stigmas stained white, 6 petals. $35 \mathrm{c}$.

1116 -Uchiu. Cerulean blue veined white, 6 petals. $35 \mathrm{c}$.

1117-Iso-no-nami. Cerulean-blue on graylilac, flaked and speckled, large yellow blotches radiating out into graceful lines, petaloid stigmas violet shaded gray, 6 petals. $35 \mathrm{c}$.

1118-Zama-no-mori. White very slightly shaded with foggy blue, yellow blotches radiating into delicate feathers, petaloid stigmas large, tipped with light blue, 3 large petals. Handsome. $50 \mathrm{c}$. 
1119-Yedo-jiman. Royal blue, large petals, standards purple, petaloid stigmas dark violet, 3 petals. $35 \mathrm{c}$.

1124 - Tora-odori (Dancing tiger). Gray overlaid with lavender-blue, yellow blotches, petaloid stigmas violet and white, 6 petals. $35 \mathrm{c}$.

1125-Koki-no-iro. Red-purple suffused with intense blue, orange, blotches, petaloid stigmas white tipped purple, 6 petals. $50 \mathrm{c}$.

1126 -Sano-watashi. Pure white, yellow blotches, petaloid stigmas creamy white, large flower, 6 petals. $35 \mathrm{c}$.

1127-Choseiden. Ruby crimson, white halo surrounds the yellow blotches, radiating into broad line, petaloid stigmas light violet, 6 petals. $35 \mathrm{c}$.

1128-Aoigata. Light purple, dark purple halo surrounds the primrose blotches, radiating into purple lines, petaloid stigmas dark purple, 3 petals. Handsome. $75 \mathrm{c}$.

1130-Bandai-no-nami. Clear white with large radiating yellow blotches, creamy standards, 6 petals. $50 \mathrm{c}$.

1131 -Oniga-shima. Six large, deep blue petals with a white halo, radiating into white lines. Handsome. $50 \mathrm{c}$.

1132 -Hana-aoi (Holly-hock). Gray, from the yellow blotches radiates dark navy blue feathers terminating in blue lilac veining, petaloid stigmas purple blue, 6 petals. $35 \mathrm{c}$.

1133 -Oku-banri. Gray feathered and penciled rich violet blotches, standards dark purple, stigmas dark violet bordered gray, late bloomer, 3 petals. Beautiful. $50 \mathrm{c}$.
1134-Komochi-guma. Violet double. $35 \mathrm{c}$.

1137-Shirataki (White water-fall). Great white petals, primrose blotches radiating gracefully into the white, petaloid stigmas creamy tipped white, 6 petals. $35 \mathrm{c}$.

1138 -Kuma-funjin (Excited bear). Purple overlaid with navy blue, 2 standards, petaloid stigmas purple and blue, very large orange blotches, 6 petals. $35 \mathrm{c}$.

1139-Datedogu. Rich claret-red with orange blotches surrounded with a blue halo radiating out into elegant lines, standards light claret and white, petaloid stigmas white tipped and bordered pale claret. Very large flower. $75 \mathrm{c}$.

1140-Sofu-no-koi. White splashed, blotched and speckled sky blue, primrose blotches, radiating into the petals, petaloid stigmas creamy white tipped and margined violet, 6 petals. Huge handsome flower. $75 \mathrm{c}$.

1041-Kuro-kumo. Purple overlaid with dark blue, yellow blotches, stigmas dark blue, bordered purple, 6 petals. $50 \mathrm{c}$.

1143 -Kumi-no-meguni. Cloudy white feathered and penciled rich violet, 6 petals. $35 \mathrm{c}$.

1146-Ho-o-jo. White petals edged with ruby crimson, 6 petals. $35 \mathrm{c}$.

1147-Tsurigi-no-mai. Bright ruby purple, deeply veined, 6 petals. Handsome. $75 \mathrm{c}$.

Mixed varieties of Japanese Irises. Per dozen roots, $\$ 3.00$.

Mixed seedlings of Japanese Irises. Many very beautiful. Per dozen, $\$ 3.50$.

(See prices on special collections on page 34.)

\section{PEONIES}

\section{"Erect in all her crimson pomp you'll see}

With bushy leaves the graceful peony."

The peony is one of the best known and nost beautiful of herbaceous plants. It is one of the hardiest and easiest of plants to grow.

The origin of the name is accounted for in various ways, but that by Homer is best known. He describes the origin of the word in Greek mythology in this manner, - Pluto had been severely wounded by Hercules and Paeon the eminent physician of Mount Olympus cured him by means of a plant, which he had obtained from his grandmother, the mother of Apollo. In gratitude, Pluto caused the plant to be called Paeonia to honor the memory of the great physician.

The early Greeks held the peony in great reverence as a sacred flower and used the roots of the plant for many medicinal purposes.

The peony of today, however, is the result of the work of such growers as Verdier, Calot, Crousse, Lamoine, Mechin and Dessert in France; Kelway \& Sons in England, and Richardson, Terry, Hollis, Rosenfield and Brand in this country, during the past seventy-five years, and is a wonderful improvement over the common red, white and pink "pineys" of our grandmothers.

Peonies require little attention and will grow in most any kind of soil. They may be planted at any time from late August until the ground freezes in the fall, and in the early spring until growth is too far advanced. Fall, however, is the best time.

In selecting our stock of peonies out of many hundred varieties we have selected the following as most reliable among the best of the distinct varieties. We send out good roots, which if planted in the fall, should bloom the following spring. Blooms will not be as perfect the first or second year as thereafter. When larger roots are desired to obtain a quick effect, two and three year old clumps can be purchased at prices stated.

The numbers before the names are our field and catalogue numbers. The figures following the names denote the value rating according to the American Peony Society. The valuation is on a scale of ten, in which a grade of 10.0 represents absolute perfection in both plant and bloom. We grow nothing below 7.0. These ratings were the result of 85 lists sent in by large Peony growers to the Society. Peonies rated 5 or below are poor varieties not worthy of a place in any garden. 


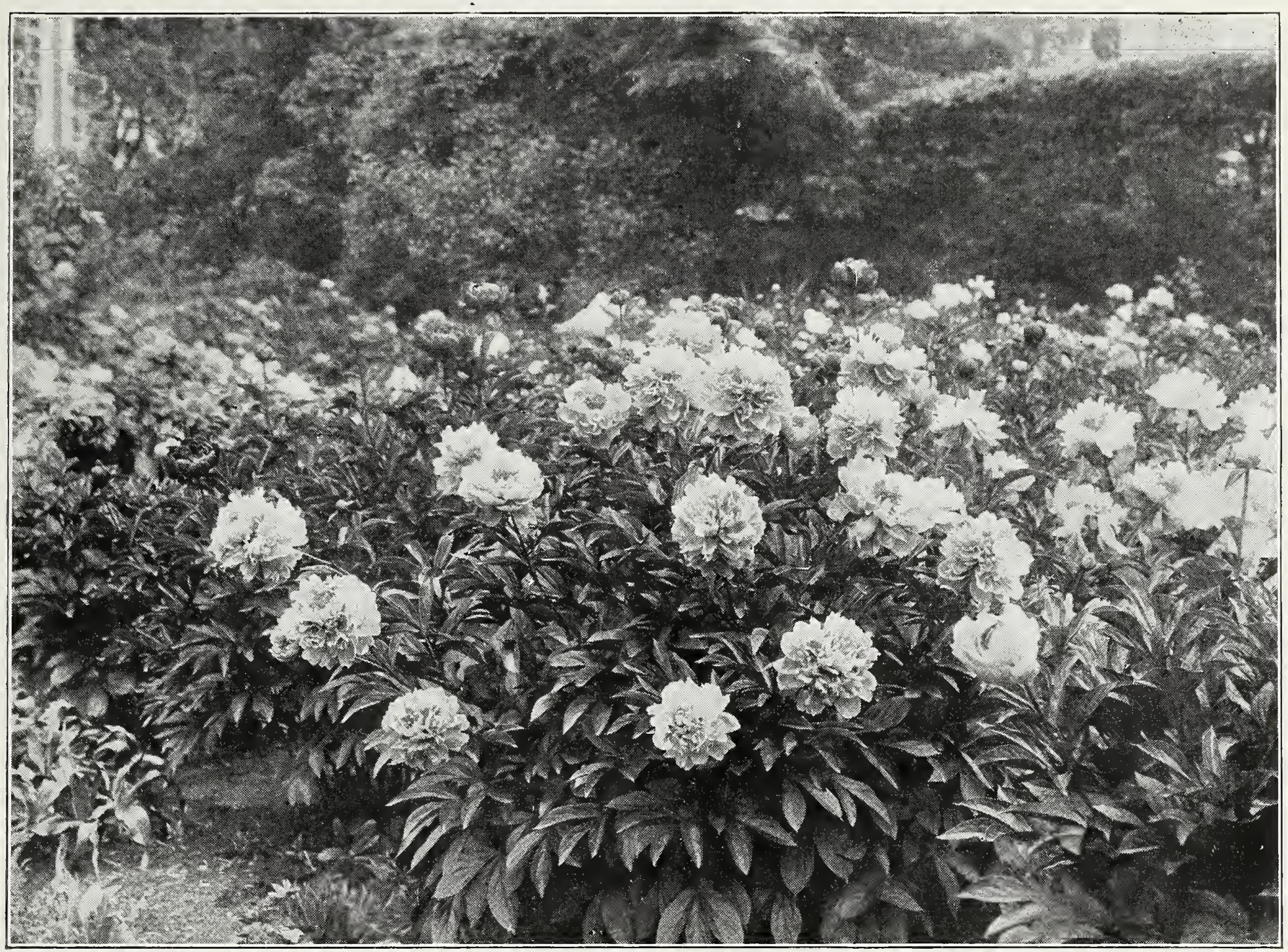

Peonies

Planting Instructions:-Do not cover the eyes or new buds with over two to three inches of soil. Too deep planting prevents blooming and causes poor growth. Do not let manure come in close contact with the roots as it will cause club root and sickly plants that will not bloom.

2326-Adolphe Rousseau 8.5 (Dessert \& Mechin 1890). Very large, semi-double. Purple garnet, very tall, vigorous grower; dark foliage, veined red. One of darkest and earliest reds and fine for landscape effects. $\$ 2.00$. Clumps, $\$ 3.50$ to $\$ 4.50$.

2342-Albert Crousse 8.6 (Crousse 1893). Very large, full bloom fresh salmon pink; bomb type; very desirable; one of the finest pinks; fragrant; late. $\$ 1.50$. Clumps, $\$ 2.50$ to $\$ 3.50$.

2377 -Alsace-Lorraine 8.8 (Lemoine 1906). Very large, flat flower with petals arranged like those of a water-lily. Creamy white with a golden halo. Tall, and a free bloomer. Distinct and beautiful and one of the best French imported varieties. Late. $\$ 5.00$.

2343-Archie Brand 7.6 (Brand 1913). Very large flower of even deep seashell pink with silvery border; bomb type; midseason, medium height, profuse bloomer; of charming beauty with delicate rose scent. $\$ 5.00$.

2378-Asa Gray 8.1 (Crousse 1886). Large, compact flower of semi-rose type. Pale lilac sprinkled with darker lilac dots. Very distinct and beautiful. Very fragrant. Medium height. Mid-season. $\$ 1.50$. Clumps, $\$ 2.50$ to $\$ 3.50$.

2301 -Avalanche 8.7 (Crousse 1886). Very large, compact, globular, rose type. Pure white, edged with a light line of carmine. Very strong, tall and very free bloomer. Mid-season. An extra fine variety. \$1.50. Clumps, $\$ 2.50$ to $\$ 3.50$.

2317 -Baroness Schroeder 9.1 (Kelway 1889). Very large, flesh-white to milk-white. Fragrant, strong, tall grower and free bloomer. Mid-season. One of the finest peonies in existence. $\$ 1.50$. Clumps, $\$ 2.50$ to $\$ 3.50$.

2361 -Ben Franklin 7. (Brand 1907). Brilliant crimson with darker shading at base of petals; very tall, blooms with great profusion; medium early; a striking dark peony, fine for massing for cut flowers and as a landscape variety. $\$ 2.00$. Clumps, $\$ 3.50$ to $\$ 4.50$.

2316 -Berloiz 7. (Crousse 1886). Rose type; late mid-season. Enormous full globular imbricated blooms, bright currant red. Center tinted rose and shaded with amaranth. As flower ages each petal is distinctly tipped silver to one-half its length. A showy, beautiful variety 
and one which attracts great attention in the garden. $65 \mathrm{c}$. Clumps, $\$ 1.25$ to $\$ 2.00$.

2362-Brand's Magnificent (Brand 1918). Deep dark red with a bluish cast; the nearest blue of any red peony; attracts great attention on account of its magnificent color effect; midseason, profuse bloomer, semi-rose; beautiful in shape. $\$ 25.00$.

2363-Charles McKellip 8. (Brand 1907). A large, rich, bright red peony; opens rose shaped and develops into the plume type; the irregular rich crimson petals of the center are mingled with golden stamens and surrounded by rows of broad silky guard petals; on account of its perfect form and deep rich ruby color, it is a great favorite. $\$ 5.00$.

2364-Cherry Hill 8.6 (Thurlow 1915). Large flowers of deep garnet, with a sheen which makes them very noticeable; semi-rose type; midseason; stems long and stiff. \$25.00.

2344-Chestine Gowdy 8.4 (Brand 1913). A striking specimen of the cone-shaped peony; shell pink with rich cream colored collar; the broad pink petals are splashed with crimson; medium late; very fragrant and attractive. $\$ 5.00$.

2354-Claire Dubois 8.7 (Crousse 1886). Very large, globular flower, rose type and uniform color, a clear deep violet rose with silvery tips; erect, tall, late; good plant, pro. fuse bloomer, splendid flower. \$1.50. Clumps, $\$ 2.50$ to $\$ 3.50$.

2302-Couronne d'Or 8.1 (Calot 1873). Large flat semi-rose type. Pure white with a ring of yellow stamens around a tuft of center petals, tipped carmine. Medium tall. Splendid grower, free bloomer. Late. 75 c. Cl $=\mathrm{mps}$, $\$ 1.25$ to $\$ 1.75$

2327-Delachei 7.1 (Delache 1856). Large, medium compact, rose type, violet crimson slightly tipped silver. Strong erect, free bloomer, fragrant. One of the finest dark red peonies. Late mid-season. $65 \mathrm{c}$. Clumps, $\$ 1.25$ to $\$ 1.75$.

2309-Duchess de Nemours 8.1 (Calot 1856). Crown type; early. Blooms several days after Festiva Maxima. Superb, cup-shaped, sulphur-white flowers with greenish reflex that lights up the entire flower; gradually changes to a pure snow white without spot or blemish. Fragrant. A grand peony. 75c. Clumps, $\$ 1.25$ to $\$ 1.75$.

2305-Edulis Superba 7.6 (Lemon 1824). Large, loose, flat crown. Bright mauve pink, collar mixed with narrow lilac. Very fragrant. Early. Strong, upright grower. Very free bloomer. 65c. Clumps, $\$ 1.25$ to $\$ 1.75$.

2330-Elizabeth Barrett Browning 9.2 (Brand 1907). Soft shell-pink when first opening, outer petals and center marked crimson; tall grower, very late, large, glossy foliage; delightfully fragrant; a grand white peony of most attractive form and beauty. Each $\$ 25.00$.

2345_Ella Wheeler Wilcox 7.6 (Brand 1907). Deep shell pink, bomb shaped; very fragrant; late; good cut flower; blossoms in clusters. $\$ 3.00$.

2313 -Eugenie Verdier 8.6 (Calot 1864). Semi-rose type. Early. Hydrangea pink, tinted lighter; center flushed crimson. Often flowers to perfection for two weeks. Early scores all the six points of excellence. A strong, healthy grower, with enormous fragrant blooms on 3 to 4 foot stems. A peony of exceedingly great beauty. $\$ 1.50$. Clumps, $\$ 2.50$ to $\$ 3.50$.

2359-Fanny Crosby $\mathbf{7 . 5}$ (Brand 1907). One row of lovely shade of soft pink guard petals, surmounted by a canary yellow; large size, tall, mid-season; one of the best yellows. $\$ 3.00$.

2355-Faribault 8.2 (Brand 1918). Deep rose with a silver sheen, strikingly different from any other rose shade; center petals silver tipped; fragrant; medium height, large flowers, good bloomer; fine for cutting and display under artificial light. Very late. $\$ 10.00$.

2307-Felix Crousse 8.4 (Crousse 1881). Large, compact, globular bomb. Brilliant red. Fragrant. Strong vigorous grower. Free bloomer. Mid-season. One of the finest red varieties. $75 \mathrm{c}$. Clumps, $\$ 1.25$ to $\$ 1.75$.

2300 -Festiva Maxima 9.3 (Mie!lez 1851). Very large globular, rose type. Pure white, flecked crimson. Very fragrant, tall, vigorous grower. Early. The most popular white variety for cut flowers. 50c. Clumps, $\$ 1.00$ to $\$ 1.50$.

2303-Floral Treasure 7.5 (Rosenfield 1900). (Syn. Delicatissima). Large, rose type. Pale lilac rose. Very fragrant, very strong, tall grower, fine habit, free bloomer. Extra good keeper and shipper. Early. 50c. Clumps, $\$ 1.00$ to $\$ 1.50$.

2331 -Florence Nightingale 8.1 (Brand 1907). A very large beautifully formed, tall, fragrant, pure white, with faint crimson markings on edges of a few petals; rose type, very late; one of the finest of white peonies. $\$ 5.00$.

2332-Francis Willard 9.1 (Brand 1907). Tall, strong grower; cream white flowers of large size, yet delicate texture; as a cut flower it remains a pinkish cream; very fragrant: very attractive and fine for cutting. Late midseason. $\$ 10.00$.

2315-Grandiflora 8.8 (Richardson 1883). Rose type; very late. Bright sea-shell pink overlaid with delicate lilac and salmon-pink. An immense, grand and beautiful peony. No collection is complete without it. $\$ 1.50$. Clumps, $\$ 2.50$ to $\$ 3.50$.

2365-Grover Cleveland 8.2 ('Terry). Very large, dark crimson, rose type; strong grower; one of 'Terry's best; late. \$2.00. Clumps, $\$ 3.50$ to $\$ 4.50$.

2366-H. F. Reddick 7.8 (Brand 1913). Large, semi-rose, brilliant dark crimson, with golden stamens showing among the petals; medium height, erect, very floriferous and tine; fragrant, late mid-season. $\$ 3.00$.

2346-Harriet Farnsley 8.2 (Brand 1916). Beautiful soft pink, similar to Madam Emile Galle, but blooms later and of better substance: rose type, large sized flowers; very late. $\$ 5.00$.

2333-Henry Avery 8.5 (Brand 1907). Creamy white with occasional markings of yellow and green in the center, giving the flower 


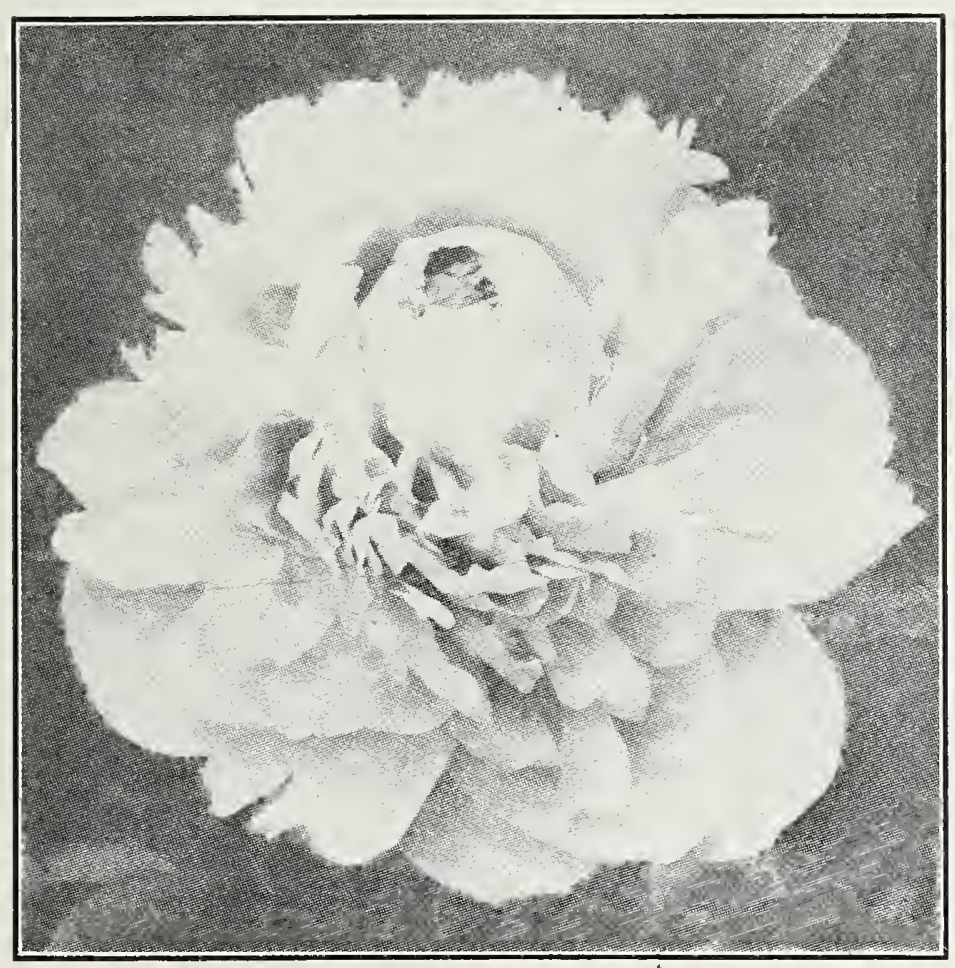

Monsieur Jules Elie

a very striking appearance; medium height, mid-season; fragrant. $\$ 10.00$.

2334-James Kelway 8.7 (Kelway 1900). Very large rose white, changing to milk white; semi-rose type; tall, strong, free bloomer; early mid-season. $\$ 1.50$. Clumps, $\$ 2.50$ to $\$ 3.50$.

2312 -Jeanne d'Arc 7.9 (Calot 1858). Soft rose; center white, tinted carmine; mid-season. A very striking variety, producing large tricolored blooms. Very beautiful. 75c. Clumps, $\$ 1.25$ to $\$ 1.75$.

2335-Jubilee 8.9 (Pleas 1908). Extremely large, flat flower, rose type; flesh-white fading to pure white, the narrow petals giving a feathery effect: fragrant, long stems, strong grower, free bloomer; greatly admired; midseason. $\$ 20.00$.

2347-Judge Berry 8.6 (Brand 1907). Delicate pink of surpassing beauty, 7-8 inches in diameter; flat semi-rose type, medium tall, profuse bloomer, very early, very fragrant, fine for cutting. $\$ 10.00$.

2367-Karl Rosenfield 8.8 (Rosenfield 1908). Very large, globular, compact, semirose type; dark crimson; very strong, tall and free bloomer; mid-season; a very brilliant, striking and favorite variety; fragrant; splendid keeper as a cut flower. $\$ 4.00$.

2336-Kelway's Glorious $\mathbf{9 . 8}$ (Kelway 1909). Enormous full double blooms of rose type; creamy white with soft blush of rose; very fragrant; a magnificent variety, considered Kelway's best; late mid-season. $\$ 35.00$.

2348-Lady Alexandra Duff 9.1 (Kelway 1902). Immense cup-shaped flower, rose type with imbricated petals; outer petals of a delicate pale pink or blush, fading rapidly to white; showy, beautiful, free flowering and robust; very fragrant; one of the finest peonies. Midseason. $\$ 15.00$.
2349-La France 9. (Lemoine 1901). Very large, compact, globular, rose type; uniform rose-white color, outer guard petals splashed crimson; tall, strong, free bloomer; very fragrant; late mid-season; one of the finest peonies. $\$ 10.00$.

2321-La Perle 8.5 (Crousse 1885). Rose type; mid-season. Very large, compact, globular flowers; color white overlaid with lilac, with a blush center; central petals flecked with carmine, sometimes splashed; free bloomer, fragrant. A beautiful and very attractive peony. $\$ 1.50$. Clumps, $\$ 2.50$ to $\$ 3.50$.

2322 - La Tulipe 7.5 (Calot 1872). Semirose type; late mid-season. Enormous, globular, fragrant flowers, delicate blush-white, shading to ivory white with red tulip markings on outside of guard petals. Very beautiful in bud. 65 c. Clumps, $\$ 1.25$ to $\$ 1.75$.

2369-Laura Dexheimer 8.3 (Brand 1913). Intense flaming crimson shading darker at base of petals; medium height, immense flowers, semi-rose type; early. \$5.00.

2337-Le Cygne 9.9 (Lemoine 1907). Enormous, perfectly formed, globular, pure milk white flower, petals very much incurved; very fragrant; erect, medium tall, stiff stem; free bloomer; mid-season; considered the finest peony in the world and has the highest rating. $\$ 20.00$.

2379-Livingstone $\mathbf{8 . 1}$ (Crousse 1879). Very large, compact flower of perfect rose type. Pale lilac-rose or soft rose-pink; center petals flecked carmine. Strong, free bloomer. Very late. Extra good variety. \$1.50. Clumps, $\$ 2.50$ to $\$ 3.50$.

2368-Longfellow 9. (Brand 1907). Very large flower of brilliant cherry crimson; claimed to be the brightest red peony in existence; very attractive, having golden stamens surrounding center petals, while the outer petals are slightly reflexed. Mid-season. \$10.00.

2338-Louise Brand 7.3 (Brand 1913). Exquisite blush white fading to white; when first opens resembles a beautiful white water lily; medium size, deep cone shaped bloom, semirose type; late mid-season; tall, good bloomer; very attractive. $\$ 5.00$.

2320-Madam Calot 8.1 (Miellez 1856). Very large rose type. Pale hydrangea-pink, center shaded slightly darker with a somewhat sulphur-tint in the collar. Tall strong grower, free bloomer. Early. Has three distinctive qualities over other peonies-freest bloomerproduces more flowers and is the most fragrant. $65 \mathrm{c}$. Clumps, $\$ 1.25$ to $\$ 1.75$.

2310 -Mme. de Verneville $\mathbf{7 . 9}$ (Crousse 1885). Large, very full, bomb. Pure white, center blush when first open, fading to pure white; prominent carmine flecks. Fragrant. Medium height, extra free bloomer. Early. One of the most charming of peonies. An extra good variety. $75 \mathrm{c}$. Clumps, $\$ 1.25$ to $\$ 1.75$.

2323-Madam Emile Galle 8.5 (Crousse 1881). Rose type; late mid-season. Large, double, cup-shaped, imbricated flowers; color delicate sea-shell-pink with touches of helio- 
trope and lavender. One of the finest peonies and scarce and rare. $\$ 1.50$. Clumps, $\$ 2.50$ to $\$ 3.50$.

2318 -Madam Emile Lemoine 8.9 (Lemoine 1899). Large, globular, compact, semi-rose type. Milk-white. Tall, strong, vigorous grower, spreading habit. Mid-season. Rare and beautiful. Fragrant. Easily scores the six points of excellence. $\$ 1.50$. Clumps, $\$ 2.50$ to $\$ 3.50$.

2325-Madam Forel 7.7 (Crousse 1881). Enormous, compact, rose-type bloom. Violetrose with a silvery tipped center. Very fragrant. Medium tall, spreading habit. Late. An extra fine variety and often called the "Princess of Pink Peonies." 75c. Clumps, $\$ 1.25$ to $\$ 1.75$.

2324-Madam Geissler 7.9 (Crousse 1880). Rose type; mid-season. Gigantic, compact, imbricated, well formed, blooms on strong, erect stems. Violet rose, tipped silver, fragrant, spreading habit. One of the largest of peonies. $\$ 1.00$. Clumps, $\$ 1.75$ to $\$ 2.50$.

2339-Mme. Jules Dessert 9.4 (Dessert 1909). Large flowers of exquisite coloring, very difficult to describe; the petals are white, but shaded with buff and salmon tints; one of the most beautiful peonies in existence; late mid-season. $\$ 8.00$.

2304-Marguerite Gerard 8.4 (Crousse 1892). Large, compact, semi-rose type. Very pale hydrangea-pink, fading to nearly white, central petal minutely flecked dark carmine, Very strong. Medium height, free bloomer. Late. An extra fine variety. \$1.50. Clumps, $\$ 2.50$ to $\$ 3.50$.

2311-Marie Lemoine 8.5 (Calot 1869). Rose type, very late. Undoubtedly Calot's Masterpiece. The flowers are enormous and massive, often 8 to 10 inches across. The abso. lutely indispensable peony to any collection, large or small. Color, ivory-white with occasional narrow carmine tracings on the edge of scme of the petals. The gigantic blooms come very late on stout, erect stems, standing well above the foliage. $\$ 1.00$. Clumps, $\$ 1.75$ to $\$ 2.50$.

2356-Martha Bullock 9.1 (Brand 1907). Mammoth cup-shaped blossoms, often nine to twelve inches across; the largest of the good peonies; soft rose pink; tall strong grower, well formed, good substance, exquisitely beautiful and fragrant. Late. $\$ 25.00$.

2370-Mary Brand 8.7 (Brand 1907). A vivid crimson with silky sheen which gives it a wonderful brilliance; golden stamens scattered through the center of irregularly fringed petals; medium height, large flowers; one of the best dark red peonies in existence; mid-season. $\$ 7.50$

2306-Mathilde de Roseneck 7.9 (Crousse 1883). Very large, globular, rose type. Uniform pale lilac-rose. Very wide petals. Center deep carmine. Very fragrant. Very tall, strong grower and free bloomer. Late. A beautiful variety. $\$ 1.00$. Clumps, $\$ 1.75$ to $\$ 2.50$.
2371-Midnight 7.3 (Brand 1907). The black peony; large, very deep maroon; semirose, plume shaped flower; medium early; magnificent for cut flowers. $\$ 3.00$.

2350-Milton Hill 9. (Richardson). Very large, compact, globular, rose type; pure lilac rose; very delicate and beautiful coloring; one of the finest. Late. $\$ 3.00$.

2380-Mons. Dupont 8.3 (Calot 1872). Large flat flower with a milk white center, splashed crimson and showing stamens. Erect, tall, free bloomer. Mid-season. $\$ 1.00$. Clumps, $\$ 1.75$ to $\$ 2.50$.

2314 -Monsieur Jules Elie 9.2 (Crousse 1888). Bomb type: early mid-season; a king among peonies and without doubt M. Crousse's masterpiece. Immense, globular, very full flowers. Color an ideal glossy lilac-pink, shading to deeper rose at the base, the entire flower overlaid with a sheen of silver that fairly shim. mers in the sunlight. Has larger blooms probably than any other peony. \$1.00. Clumps, $\$ 1.75$ to $\$ 2.50$. (See page 28.)

2372-Mons. Martin Cahuzac 9. (Dessert 1899). Good sized globular flower of very dark purple garnet with black reflex; said to be the darkest peony in existence; strong, vigorous and free bloomer; a distinct and handsome variety; early mid-season. \$5.00.

2340-Mrs. A. W. Ruggles 8.2 (Brand 1913). White, delicately suffused with lilac gradually fading to white; large, semi-rose; late, fragrant; flowers in great clusters. $\$ 10.00$.

2381 -Octavie Demay 8.5 (Calot 1867). Very large, full flower of crown type. Color delicate pink and white. Free bloomer. Dwarf. Fragrant and very beautiful. Early. \$1.50. Clumps, $\$ 2.50$ to $\$ 3.50$.

2373-Old Silver Tip 7.6 (Brand 1918). Soft madder red with silver tipped petals giving a silvery sheen; profuse bloomer, semirose type; large flowers, strong grower; good for cutting or landscape; midseason. $\$ 10.00$.

2357-Phoebe Cary 8.8 (Brand 1907). A beautiful rose pink with center slightly deeper in shade; large flowers, rose type; fragrant, tall, late; a grand and especially attractive peony. $\$ 10.00$.

2360-Primevere $\mathbf{8 . 6}$ (Lemoine 1907). Large flower, bomb type, having outer petals buff and center sulphur yellow; tall, strong grower, free bloomer; very fragrant, very fine; mid-season. $\$ 6.00$.

2374 - Prince of Darkness 7.6 (Brand 1907). An exceptionally rich dark maroon peony; one of the very darkest; opens early and lasts long; large loose, semi-rose; good bloomer; fine for cutting or landscape. $\$ 2.00$.

2375-Richard Carvel 8.8 (Brand 1913). Very early, deep red; immense globular bomb; tall, profuse bloomer; fragrant and beautiful; best of all early dark reds. $\$ 5.00$.

2308-Rubra Superba 7.2 (Richardson 1871). Large compact, rose type. Deep rose carmine or crimson. Fragrant. Very late. Considered the best late crimson. $50 \mathrm{c}$. Clumps, $\$ 1.00$ to $\$ 1.50$. 
2351 -Ruth Brand 8.1 (Brand 1907). A uniform soft lavender pink, splashed with deeper lavender; tall, large, compact, bomb; midseason; beautiful coloring, fragrant. $\$ 2.50$.

2358-Sarah Bernhardt 9. (Lemoine 1906). Large flower of perfect form, semi-rose type; apple blossom pink with each petal silver-tipped giving the appearance of a distinct border of pure white; strong grower, free bloomer; very fragrant; late mid-season. $\$ 5.00$.

2341 -Solange 9.7 (Lemoine 1907). Unusually large, full, compact, globular, crown type; outer petals very delicate lilac white, deepening toward the center with salmon shading; an unusual and undescribable coloring of rare beauty; strong grower and free bloomer; considered one of the three best in the world; very late. $\$ 10.00$.

2319-Solfatare 7.6 (Calot 1861). Crown type; mid-season; milk-white guards, sulphur collar, fading to sulphur white. One of the nearest to a yellow peony. Fragrant, medium height, spreading habit. Free bloomer. Fine for cut flowers. A very desirable variety. $75 \mathrm{c}$. Clumps, $\$ 1.25$ to $\$ 1.75$.

2352-Therese 9.8 (Dessert 1904). Rose type; flowers enormous in great quantities on stout stems; most delicate, rich satiny pink with glossy reflex; early; very handsome;
Dessert's best production, and one of the most desirable varieties; a prize winner at every exhibition. \$6.00.

2353-Tourangelle $\mathbf{9 . 4}$ (Dessert 1910). Large, flat flower, of rose type; flesh pink tinged with salmon; exquisitely delicate in shading; one of the finest and most desirable; strong grower, free bloomer; very fragrant; mid-season. $\$ 7.50$.

2382-Venus 8.3 (Kelway). Very large flower of a delicate shell-pink. Strong grower. Tall, free bloomer. Beautiful. Makes an ideal cut-flower. Very fragrant. Mid-season. \$2.00.

2383-Walter Faxon $\mathbf{9 . 3}$ (Richardson). Large, globular semi-rose type. Color uniform, pure bright rose, deepening toward the center. Very distinct and delicate color. Strong grower and free bloomer. Mid-season, scarce. $\$ 7.50$

2376 - Winnefred Domme 7.6 (Brand 1913). Medium sized flower, brilliant dark red; tall, prominent, bomb center; profuse bloomer, medium early. $\$ 5.00$.

\section{SINGLE JAPANESE HERBACEOUS PEONY}

2328-Mikado 8.6. Large flower, dark crimson with narrow filamental petals, crimson edged and tipped golden; very late; free bloomer; very attractive. $\$ 3.50$.

(For special collections, see page 34. )

\section{OUR VARIETIES OF PEONIES CLASSIFIED AS TO COLOR}

Abbreviations denote time of flowering, viz.: V. E.-Very Early; M. E.-Medium Early; E. M.--Early Midseason; M.-Midseason; L. M.-Late Midseason; M. L.-Medium Late; L.-Late; V. L.-Very Late.

\section{White to Cream}

Alsace Lorraine (L.)

Avalanche (M.)

Baroness Schroeder (M.)

Couronne d'Or (L.)

Duchess de Nemours (E.)

Elizabeth Barrett

Browning (V. L.)

Festiva Maxima (E.)

Florence Nightingale (V. L.)

Frances Willard (L. M.)

Henry Avery (M.)

James Kelway (E. M.)

Jubilee (M.)

Kelway's Glorious (L. M.)

Le Cygne (M.)

Marie Lemoine (V. L.)

Mme. de Verneville (E.)

Mme. Emile Lemoine (M.)

Mme. Jules Dessert (L. M.)

Mons. Dupont (M.)

Mrs. A. W. Ruggles (L.)

$$
\text { Yellow }
$$

Fannie Crosby (M.)

Primevere (M.)

Solfatare (M.)

Blush or Flesh Color

Asa Gray (M.)

Chestine Gowdy (M. L.)

Eugenie Verdier (E.)

Grandiflora (V. L.)
Blue or Flesh Color-Continued Harriet Farnsley (V. L.)

Judge Berry (V. E.)

Lady Alexander Duff (M.)

La Perle (M.)

LaTulipe (M.)

Louise Brand (L. M.)

Madam Calot (E.)

Marguerite Gerard (L.)

Milton Hill (V. L.)

Octavie Demay (E.)

Solange (V. L.)

Therese (E.)

Tourangelle (M.)

Venus (M.)

\section{Medium Pink}

Albert Crousse (L.)

Archie Brand (M.)

Ella Wheeler Wilcox (L.)

Floral Treasure (E.)

Jeanne d'Arc (M.)

La France (L. M.)

Livingstone (V. L.)

Mme. Emile Galle (L. M.)

Martha Bullock (L.)

Mathilde de Roseneck (L.)

Mons Jules Elie (E. M.)

Medium Pink (Cont'd)

Phoebe Cary (L.)

Ruth Brand (M.)

Sarah Bernhart (L. M.)

\section{Deeper Pink}

Claire du Bois (L.)

Edulis Superba (E.)

Faribault (V. L.)

Madam Forel (L.)

Mme. Geissler (M.)

Walter Faxon (M.)

Red

Berloiz (L. M.)

Charles McKellip (M.)

Felix Crousse (M.)

Karl Rosenfield (M.)

Laura Dexheimer (E.)

Longfellow (M.)

Mary Brand (M.)

Old Silver Tip (M.)

Rubra Superba (V. L.) Deep Red and Purple

Adolphe Rosseau (E.)

Ben Franklin (M. E.)

Brand's Magnificent (M.)

Cherry Hill (M.)

Delachei (L. M.)

Grover Cleveland (L.)

H. F. Reddick (L. M.)

Midnight (M. E.)

Mons. Martin Cahuzac (E. M.)

Prince of Darkness (E.)

Richard Carvel (E.)

Winnefred Domme (M. E.) Japanese Single

Mikado (V. L.) 


\section{GLADIOLI (Bulbs) (See Illustration on Back Cover)}

For beauitful flowers from July until late fall there are none so dependable and magnificent or that give more satisfaction than gladioli. As cut flowers, they have no peer and when planted in clumps and masses in the garden they invariably make a grand showing.

The word gladiolus is Latin, meaning a dagger in allusion to the shape of the leaves. The native gladioli were brought into Europe from southern Africa about the middle of the eighteenth century. The famous house of Van Houtte took up the plant and introduced it in 1841 into the wider gardening world and as we know it today, the gladiolus is a triumph of the gardener's art.

A number of exquisitely beautiful varieties have been introduced the past few years and after several years of experimenting and discarding we are offering a collection of the best and choicest varieties, any one or all of which the flower lover will be justly proud of. In purchasing gladioli bulbs it is best to get what is worth while and the best named varieties give the most satisfaction. By ordinary care and in cutting as explained below, your collection will steadily increase so that your garden will soon have a considerable showing.

When To Order the Bulbs. Orders for gladioli are shipped in November, weather conditions permitting, and from April 1st until May 10th when we plant our stock. Shipments ordered during the winter must be at the purchaser's risk. We send out first-class, sound, northern grown bulbs of large size. Some varieties do not make as large bulbs as others, however. Send in your order as early as possible to assure early delivery and of the varieties desired for although we usually carry a large supply, the demand for our beautiful varieties is very heavy. All quotations are subject to stock being unsold on receipt of order. No substitrsion will be made except upon your directions.

Planting Instructions. If weather conditions permit start planting in April or first parc of May and plant at intervals up to June 20th to secure a succession of flowers from July until late fall. It usually takes from 65 to 80 days from time of planting until flowering, depending on the variety, size of bulb, soil and weather conditions. If possible use a new location each year not planting in the same location oftener than every third year. If a good coating of manure is spaded in deeply in the fall and well spaded and pulverized in the spring, the soil will be in fine condition. If used only at planting, it is better to use high-grade commercial fertilizers such as bone meal, pulverized sheep manure or a liquid fertilizer applied to the soil near the rows but not too close to the bulbs. Deep planting is necessary in order to properly develop the new bulb which grows on top of the old one. Plant six inches deep with less on very heavy soils. Deep planting gives a heavy stalk and saves the necessity of using stakes. By planting the bulbs in round, oblong or square beds allowing from four to six inches apart between the bulbs will give opportunity for weeding and hoeing. To pi vent soil crust forming keep the soil well worked. Thorough waterings in the evening during development aid considerably. Applying Scotch soot to the soil when plants are half grown intensifies deep shades and by applying weak lime water to soil shortly before blooms open will clarify the more delicate shades.

Cutting. When cutting the flowers leave at least two to four leaves. The bulbs need them to assist in their ripening. If the spikes are cut when the first buds open, their stems cut off a bit every day and the water changed, every bud will open. Treated in this way the flowers will last from ten days to two weeks.

Digging and Care of Bulbs. Before the ground freezes in the fall dig up the bulbs using a spading fork if possible. Take up the bulbs carefully if you desire to save the bulblets and cut off the stalk about one-half inch from the bulb. Allow to dry for a week or more before removing the old corn from the new bulb and the bulblets. The old corn is worthless and should be thrown away. Plant the bulblets the following spring in shallow trenches and the second year they should flower. After removing the old corn and bulblets allow the bulbs to be exposed to the sun or other heat until thoroughly dried and cured, then pack in bags or shallow boxes and place for the winter in a cool, dry place in the cellar where the temperature will not go below freezing point.

As far as possible we give the name of introducer after name of variety. Prices quoted on Gladioli include parcel post charges on 24 bulbs or less. Twenty-five or more will be sent express or parcel post collect. No charge for packing. See directions for ordering on inside page of front cover.

Six bulbs will be furnished at dozen rates, 25 at the 100 rate.

1400-America (Banning). A beautiful soft flesh-pink, one of the fin-

est varieties. Fine for cutting............... Color, cream yellow, upper

Each Dozen

100 petals suffused with peach blossom pink, lower petals striped carmine-red; one of the finest late varieties..
$\$ 0.05 \$ 0.50$ 
1402-Baron Hulot (Lemoine 1910). A beautiful rich indigo blue.

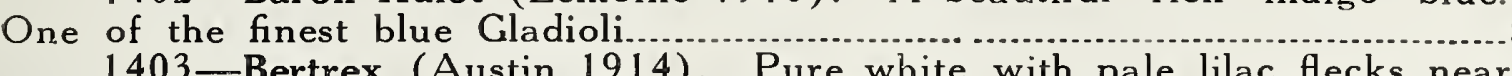
edge of petals; flower 4 inches, of great substance; trifle ruffled; fine cut flower

1404-Blue Hybrids. Similar to Baron Hulot; beautiful indigo blue, but later flowering. Fine for cutting.

1405-Blue Jay (Groff 1904). Lobelia blue splashed with deeper lobelia blue. Lemon yellow throat blotched violet. An unusual color. Very desirable

1406-Brenchleyensis (Youell). An old but fine variety; color, ver-

milion-scarlet; fine for massing
1407 Crimson Glow (Betcher 1916). Extra tall strong spike with Each Dozen

100 mammoth brilliant crimson flowers. The finest crimson. Handsome.......
1408 -Empress of India (Velthuys 1908). Rich velvety dark maroon. Rare and beautiful color...

1409-Europa (Pfitzer 1911). Pure white, very large spike, the finest exhibition white

1410-Evelyn Kirtland (Austin 1916). Beautiful shade of rosy pink, darker at the edges, fading to shell pink at the center, with brilliant scarlet blotches on lower petals. A glistening, spark!ing lustre. Tall straight spike. Wonderfully decorative.

1411-Flora (Velthuys 1917). Beautiful golden yellow, very large

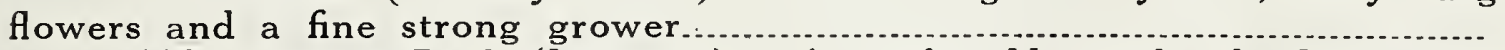

1412-George Paul (Lemoine). A perfect Harvard red. Large flow-

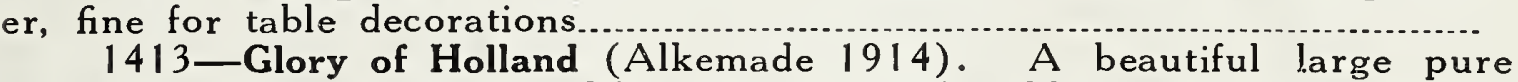
white tinted rose; strong healthy grower and free bloomer darker stripes. Fine exhibition variety

1415-Goliath (Velthuys 1913). Extra large wide open flower, deep velvety wine; extra fine, dark red; large spike; beautiful

1416-Gretchen Zang (Austin 1915). Large sparkling blooms, most beautiful soft melting pink, blending into scarlet on long petals

1417 - Halley (Velthuys). Very large delicate salmon pink with light creamy blotch, earliest large flowering Gladiolus to bloom; fine for garden and for cutting

1418-Herada (Austin 1916). Large blooms of pure mauve, glistening and clear, with deeper markings in throat. Very attractive and unusual color

1419 -Ida Van. Beautiful deep salmon red, or flaming orange pink;

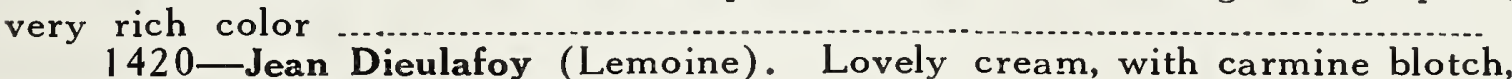

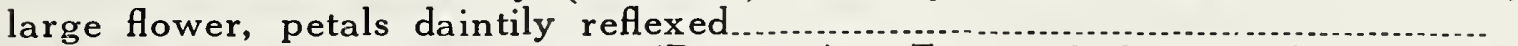

1421 -Le Marechal Foch (Deursen). Extremely large, light rose pink and blooms early. The finest cut flower variety that ever came from Holland

1422 -Loveliness. Pale reddish salmon, throat amber white penciled rosy magenta. Very fine large flowers. Fine for cutting ......................

1423-Master Wietze. Beautiful dark violet; a new color; large and unusual

1424-Minnesota. Pale cream, small maroon blotch …................. like a rose, handsome..............................................

1426-Mrs. Frances King (Coblentz). A striking shade of light scarlet or flame color, most effective both for beds and cutting

1427-Mrs. Frank Pendleton (Kunderd). Light pink, heavily blotched with blood red on throat. A remarkably attractive and beautiful variety....

1428-Mrs. Watt. Glowing American Beauty shade-self color. Nearly all the flowers open at one time. Distinct and beautiful

1429-Myrtle (Kunderd). Tender and delicate rose-pink. The most beautiful pink yet produced

$0.12 \$ 1.20$

$\$ 9.00$

$.20 \quad 2.00 \quad 15.00$

$.10 \quad 1.00 \quad 7.50$

.20

2.00

15.00

.05

.50

$.50 \quad 5.00$

$.10 \quad 1.00$

7.50

.25

2.50

18.50

.20

$2.00 \quad 15.00$

.30

3.00

22.00

.10

1.00

7.50

.10

1.00

7.50

.10

1.00

7.50

.20

2.00

15.00

.15

1.50

11.00

.70

1430 -Niagara. A charming variety with immense flowers of soft Nankeen yellow; throat tinged pink and penciled carmine. A fine cut flower

1431-Panama (Banning). A grand seedling of America but is of deeper pink; flowers very large and spike long. 
1432-Peace (Groff). Grand large flowers, white with claret blotch on lower petal and pale lilac featherings. Late..............................................

1433-Pink Perfection. Delicate apple blossom with a white stripe in the center of each petal and a dark rose feathered border. Large beautiful flowers

1434 -Pride of Goshen. A very large bloom of flesh pink with waved petals. A strong grower and strikingly beautiful

1435-Princeps (Vaughan). Immense flowers of rich crimson-scarlet with large white throat blotch on lower petals .............................................

1436-Prince of Wales. A clear grenadine pink or deep buff, with throat markings of a deeper tone. The tips of petals shaded darker or apricot buff.

1437-Roem Van Kennemerland. Beautiful lilac rose, immense flowers 5 in. across 1438 -Scarsdale (Cowee). Rosy magenta, splashed with a deeper

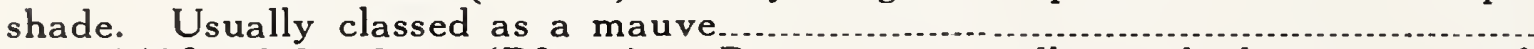

1439 -Schwaben (Pfitzer). Pure canary-yellow, shading to a soft sulphur yellow. Magnificent. Weep scarlet; paler in throat, flaked blood red with lighter middle line. One of the finest reds. Blooms very late.............

1441 -Wilbrink. A sport of Halley. Retains Halley's earliness and has the color of America, soft yellow blotch on lower petals: very attractive 1442-Willie Wigman. Beautiful blush, white, long bright scarlet blotch on lower petals; most attractive....................................................

1443-Primulinus Hybrids. A smaller type of Gladioli than any of the above but exquisitely beautiful. Dainty in form and arrangement on graceful spikes. Colors range from lightest primrose, through apricots, yellows, orange and bronze, to deep, rich rose and reds. Flower earlier than

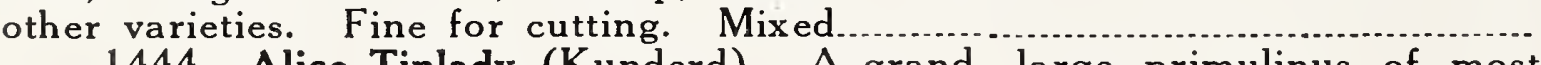

1444 - Alice Tiplady (Kunderd). A grand, large primulinus of most beautiful orange saffron color. Very choice.........................................

1445-Rainbow Mixture of Gladioli. This is a superb mixture of a large number of high class beautiful varieties of Gladioli and includes many of the above named fine expensive varieties. A wide range of color and many of the blooms are ruffled.

Large bulbs: Per Dozen 75c; Per $100 \$ 5.00$; Per $250 \$ 11.25$; Per $500 \$ 19.00 ;$ Per $1000 \$ 35.00$.

(See special collections of Gladioli on page 34.)

\section{OUR VARIETIES OF GLADIOLI CLASSIFIED AS TO COLOR}

\section{WHITE}

Europa (pure white)

Bertrex (white, pale lilac flecks).

Glory of Holland (pure white, tinted rose).

Peace (claret blotch and pale lilac featherings).

Willie Wigman (with scarlet blotch).

\section{CREAM-YELLOW.}

Minnesota (pale cream, small maroon blotch).

Autumn Queen (suffused peach blossom pink).

Jean Dieulafoy (cream, carmine blotch).

Niagara (Nankeen yellow).

Schwaben (canary to soft sulphur yellow).

Flora (golden yellow).

Prince of Wales (grenadine pink or deep buff).

Also Primulinus Hybrids.

\section{ORANGE}

Golden West (orange scarlet with darker stripes).

Alice Tiplady, Prim. (orange saffron).

Also Primulinus Hybrids.

\section{PINK}

Flesh Pink-America.

Pride of Goshen (waved petals).

Wilbrink (soft yellow blotch).

Salmon-to Pure Pink-Halley (salmon pink).

Pink Perfection (apple blossom pink).

Loveliness (pale reddish salmon).

Gretchen Zang (soft melting pink blended scarlet).

Mrs. Frank Pendleton (blotched blood red).
Rose Pink-Myrtle (delicate rose pink).

Le Marechal Foch (light rose pink).

Evelyn Kirtland (rose pink, scarlet blotches).

Deeper Pink-Monmouth; Panama.

Flaming Orange Pink-Ida Van.

\section{RED}

Light Scarlet-Mrs. Frances King.

Scarlet with Fiery Glow-Princeps (white blotch).

American Beauty Shade-Mrs. Watt.

Vermilion Scarlet-Brenchleyensis.

Cardinal or Deep Scarlet-War.

Crimson-Crimson Glow (brilliant crimson).

Maroon-Empress of India (velvety dark maroon).

George Paul (Harvard red).

Goliath (deep velvety wine-darkest).

\section{LILAC}

Roem Van Kennemerland (lilac rose).

\section{MAUVE}

Herada (pure mauve).

Scarsdale (rosy magenta, usually classed as mauve).

\section{VIOLET}

Master Wietze (dark violet).

BLUE

Lobelia Blue-Blue Jay (blotch, bordered yellow).

Indigo Blue-Baron Hulot; Blue Hybrids. 


\section{SPECIAL COLLECTIONS}

To introduce our Specialties and in order to get our customers interested in Irises, Peonies and Gladioli, we have always listed a series of Special Collections made up of first class varieties, which have always been popular and in great demand. The following Collections will be found to be of the same high standard.

\section{IRISES}

\section{Special Collections of Beautiful Intermediate and Tall Bearded Irises.}

A-12 beautiful choice named varieties, our selection $\$ 3.00$

$\mathrm{B}-25$ beautiful choice named varieties, our selection

(Collections B and C include many of the more expensive varieties. The price list of above would total considerably more.)

D-Continuous Blooming Collection: 3 Dwarf, 3 Int., 2 Late May, 8 Tall Bearded, 2 Siberian and 2 Japanese Irises, total 20 different, our selection (list price over $\$ 6.00$ ) ........... $\$ 5.00$

E-Continuous Blooming Collection: Same but twice the number of each of the foregoing collection, our selection (list price over \$12.00)

$\$ 10.00$

\section{PEONIES}

\section{Special Collections of Magnificent All Color Combinations.}

F-One root each of Couronne d'Or, Fesíiva Maxima, Marie Lemoine, La Tulipe, Madam Calot, Floral Treasure, Jeanne d'Arc, Madam Forel, Felix Crousse and Delachei, all labeled (list price $\$ 6.95$ )

G-One root each of Mons Dupont, Mme. Emile Lemoine, Solfatare, Grandiflora, Marguerite Gerard, Albert Crousse, Mathilde de Roseneck, Mme. Geissler, Berloiz and Ben Franklin, all

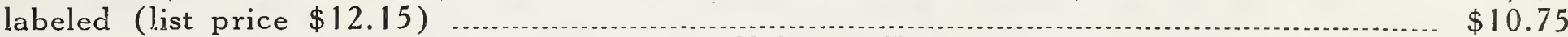
H-One root each of Avalanche, James Kelway, Eugenie Verdier, La Perle, Mme. Emile Galle, Mons Jules Elie, Claire du Bois, Rubra Superba, Adolphe Rosseau and Grover Cleveland, all labeled (list price \$14.50)

I-One root each of Baroness Schroeder, Fanny Crosby, Milton Hill, Venus, Ella Wheeler Wilcox, Ruth Brand, Charles McKellip and Richard Carvel, all labeled (list price \$25.50)..\$23.50

J-One root each of Alsace Lorraine, Primevere, Therese, Sarah Bernhardt, Walter Faxon, Karl Rosenfield, Mons. Martin Cahuzac, and Mikado, all labeled ( 8 of the highest grade and rat-

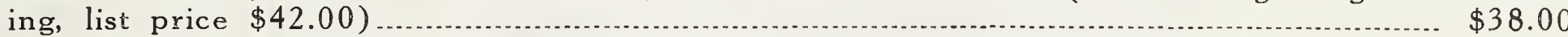
(Each of cur Peony Collections is of different varieties from the other.)

\section{GLADIOLI}

\section{Color Scheme Collections of Beautiful Varieties.}

White, cream, yellow, orange combinations.

$\mathrm{K}-50$ bulbs - not less than 8 varieties, labeled (list price over $\$ 4.40$ )

L-100 bulbs-not less than 10 varieties, labeled (list price over $\$ 9.00$ )

White and pink combinations.

M-50 bulbs-not less than 9 varieties, labeled (listed over $\$ 4.40$ )

$\mathrm{N}$ - 100 bulbs-not less than 12 varieties, labeled (listed over $\$ 9.25$ )

Pink combination-various shades.

O-50 bulbs-not less than 10 varieties, labeled (listed over $\$ 4.80$ ).

$\mathrm{P}$ - 100 bulbs - not less than 12 varieties, labeled (listed over $\$ 10.00$ )

Red combinations-various shades.

$\mathrm{Q}-50$ bulbs-not less than 6 varieties, labeled (listed over $\$ 3.70$ ).

$\mathrm{R}$ - 100 bulbs-not less than 8 varieties, labeled (listed over $\$ 8.00$ )

Blue and white combinations-beautiful effect.

$\mathrm{S}-75$ bulbs - not less than 6 varieties, labeled (listed over $\$ 8.60$ )

$\mathrm{T}-150$ bulbs-not less than 6 varieties, labeled (listed over $\$ 17.20$ )

See also our Rainbow Mixture of Gladioli and of Mixed Primulinus Hybrids on Page 33. 


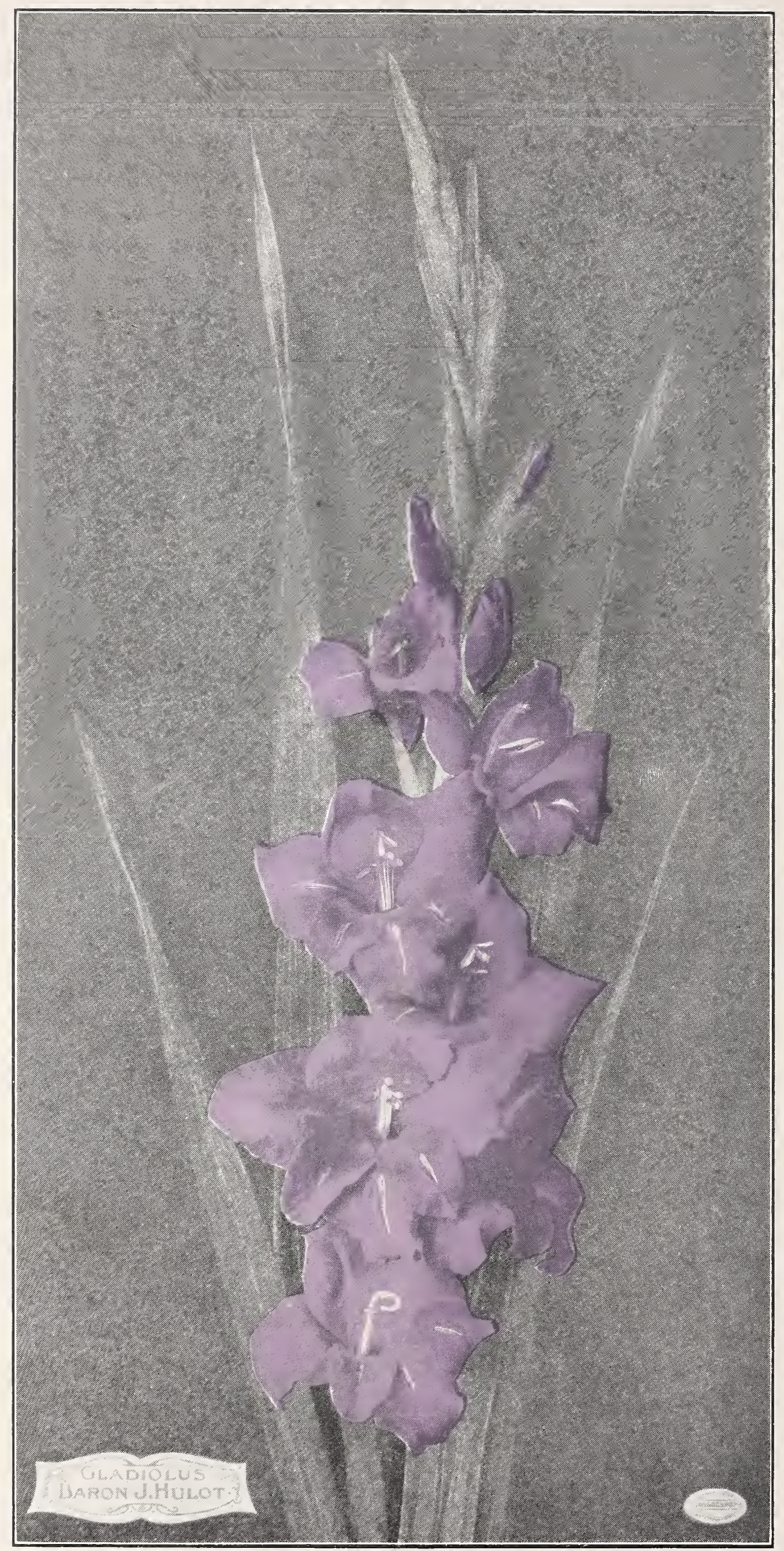

Baron J. Hulot (Gladiolus) 